\title{
UMA ANÁLISE SOBRE A ADEQUAÇÃO DA GESTÃO ESTRATÉGICA DE CUSTOS NA FORMAÇÃO E GERÊNCIA DE EMPRESAS VIRTUAIS
}

Luciano Mitidieri Bento Garcia

Dissertação apresentada à Escola de Engenharia de São Carlos da Universidade de São Paulo, como parte dos requisitos para obtenção do Título de Mestre em Engenharia de Produção

ORIENTADOR: Prof. Dr. Carlos Frederico Bremer

São Carlos

1998 
À minha esposa

meus familiares pelo precioso apoio 
Ao Professor Doutor Carlos Frederico Bremer, pela orientação fornecida neste trabalho e pelo decisivo incentivo.

À Coordenadoria de Pós-Graduação do Departamento de Engenharia de Produção da EESC/USP por ter acreditado na finalização deste trabalho. 


\section{SUMÁRIO}

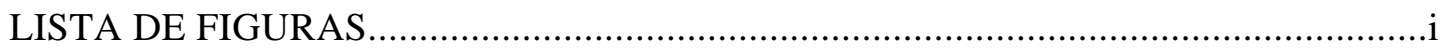

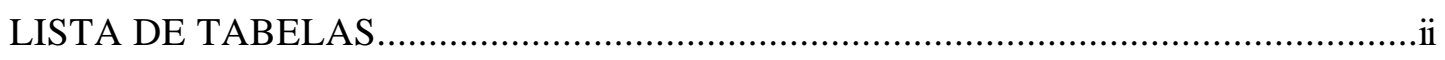

LISTA DE ABREVIATURAS E SIGLAS.............................................................ii

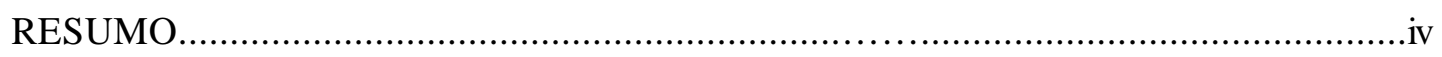

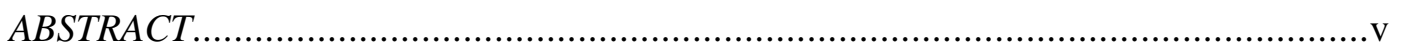

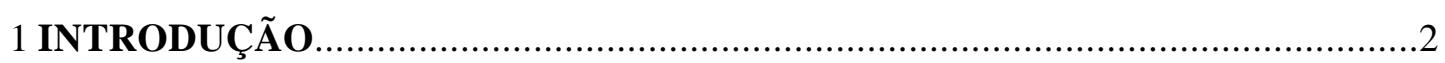

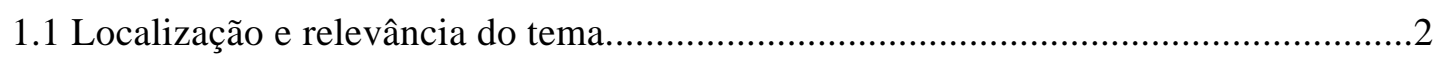

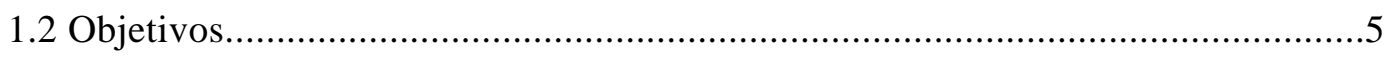

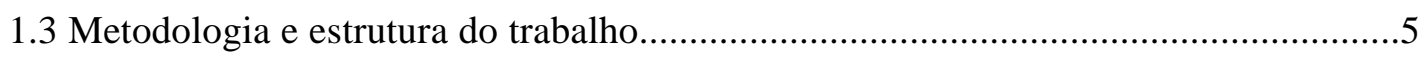

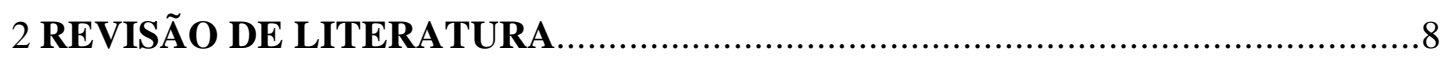

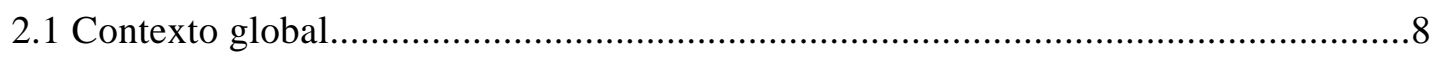

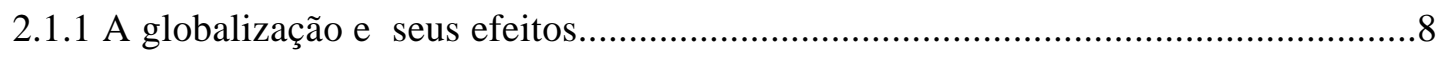

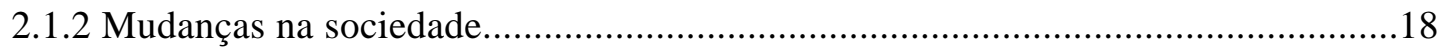

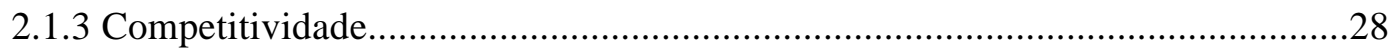

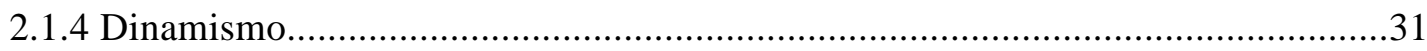

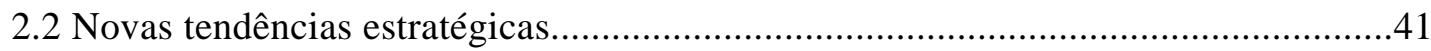

2.2.1 Estratégia competitiva e vantagem competitiva....................................................

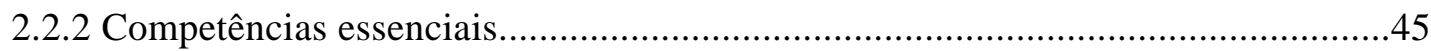

2.3 Visão econômica sobre cooperação e redes de empresas..............................................51

2.3.1 Redes estratégicas e gestão estratégica de custos....................................................56

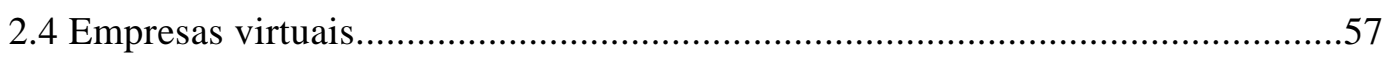

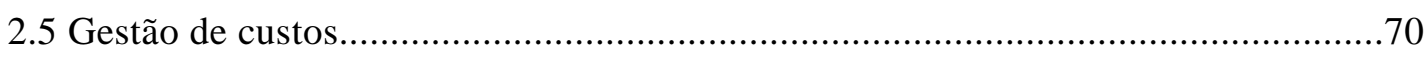

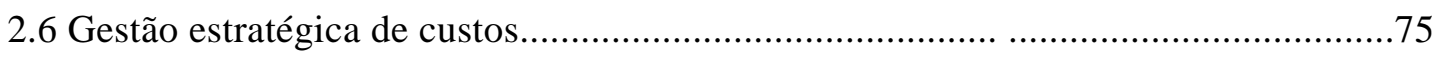

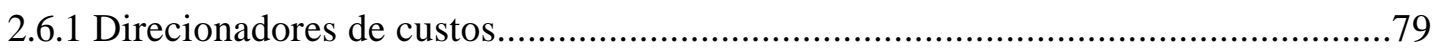

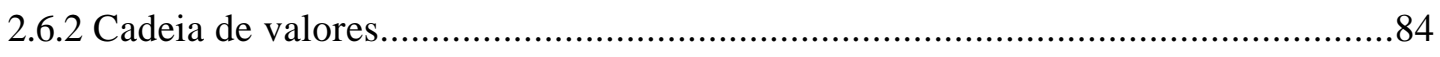

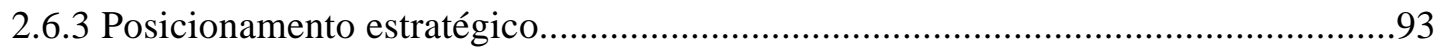

3 A GESTÃO ESTRATÉGICA DE CUSTOS EM EMPRESAS VIRTUAIS..............97

3.1 Definição de critérios para empresas virtuais................................................................97

3.2 Definição de critérios para a gestão estratégica de custos..........................................104

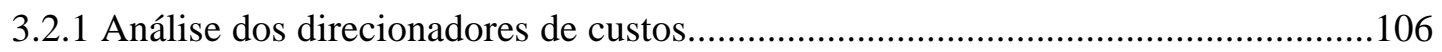




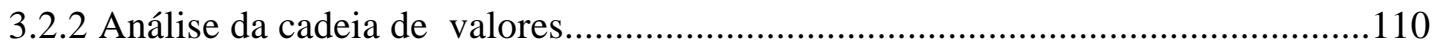

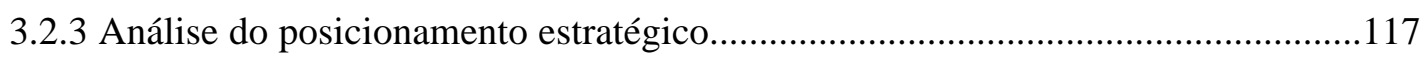

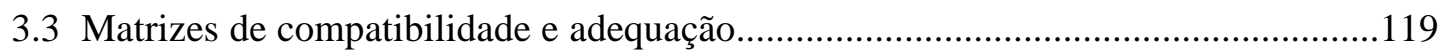

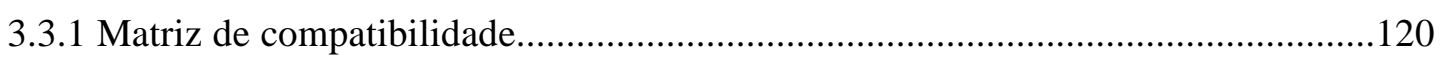

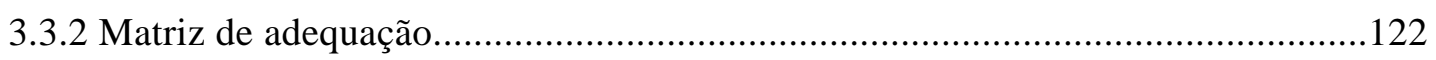

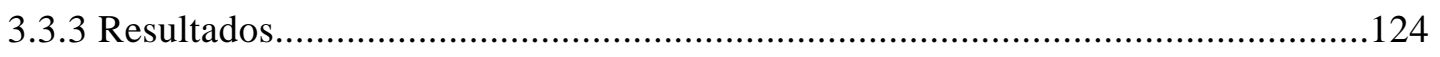

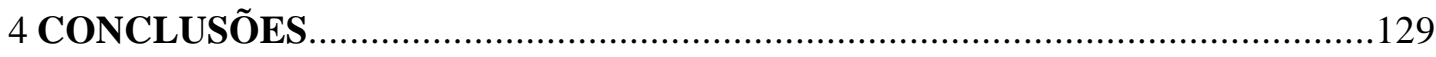

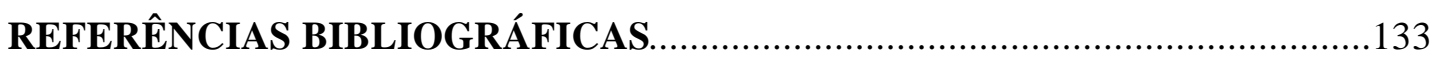




\section{LISTA DE FIGURAS}

FIGURA 01 - Cadeia de Valores da Indústria de Produtos de Papel...............................116

FIGURA 02 - Matriz de Compatibilidade de ferramentas de SCM x processos de EV.....121

FIGURA 03 - Matriz de Adequação de ferramentas de SCM x processos de EV...

.124 


\section{LISTA DE TABELAS}

TABELA 1 - Relações entre centros de custos e direcionadores de custos... 


\section{LISTA DE ABREVIATURAS E SIGLAS}

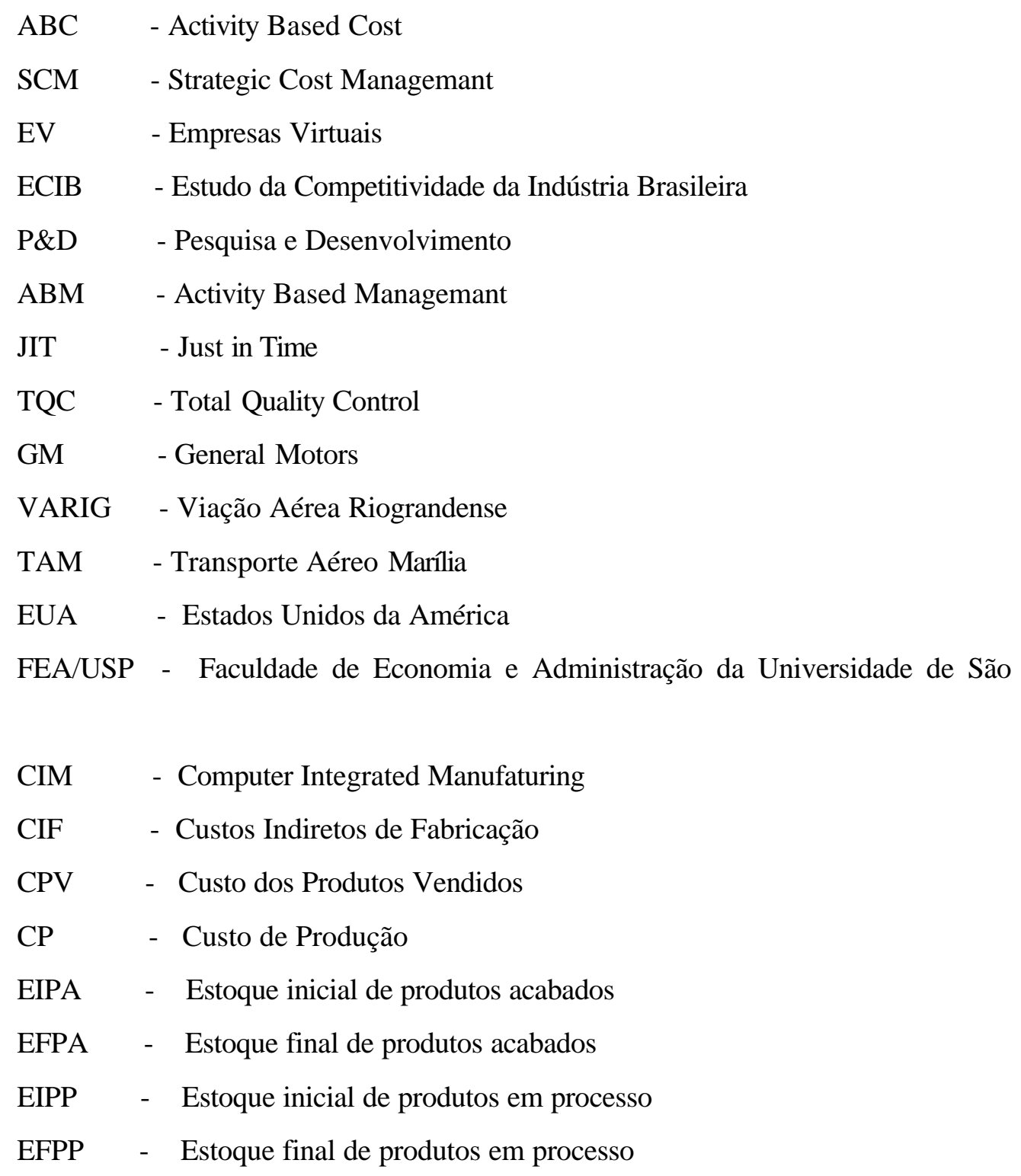




\section{RESUMO}

GARCIA,L. M. B. (1998). Uma análise sobre a adequação da Gestão Estratégica de Custos na formação e gerência de Empresas Virtuais. São Carlos, 1998. 153 p. Dissertação

(Mestrado) - Escola de Engenharia de São Carlos, Universidade de São Paulo.

A análise de custos tradicional apenas estuda os impactos financeiros das alternativas de decisão. Mas dentro de um ambiente de concorrência ágil, globalizada e cada vez mais acirrada, a obtenção de vantagens competitivas sustentáveis torna-se fundamental e portanto, os elementos estratégicos devem ser agregados aos dados de custos. Com o advento da globalização, surge uma nova concepção de se encarar o ambiente empresarial e operar dentro dele. Os conceitos de dinamismo, vantagens competitivas, competências essenciais, acabam possibilitando novas concepções de arranjos organizacionais tais como as redes de cooperação de empresas denominadas Empresas Virtuais (EV), e se constituem em enfoques dos mais importantes. As empresas com base tecnológica, devido a sua agilidade intrínseca, possuem um perfil propício para atuar sob a forma de Empresas Virtuais. Também o conceito de estratégia, principalmente aplicado a gestão de custos/lucros é uma realidade trazida pelo novo contexto global. A aplicação da Gestão Estratégica de Custos (Strategic Cost Managemant - SCM) e de suas ferramentas está associada a todas as atividades das empresas, especialmente àquelas relacionadas com a gestão de custos e lucros. É objetivo deste trabalho estudar e discutir os critérios de funcionamento de um modelo de Gestão Estratégica de Custos e as possibilidades de sua aplicação em Empresas Virtuais. A meta é a obtenção de conclusões e conhecimento a cerca da administração de custos de uma maneira estratégica para o setor de Empresas Virtuais.

Palavras-chave: Gestão Estratégica de Custos, Empresas Virtuais, vantagens competitivas 


\section{ABSTRACT}

GARCIA,L. M. B. (1998). One análysis about the adjustment of the strategic cost managemant on formation and administration of virtual organizations. São Carlos, 1998. 155 p. Dissertação (Mestrado) - Escola de Engenharia de São Carlos, Universidade de São Paulo.

The tradicional cost analysis only studies the financial consequences of alternative decisions. But in a environment of agile, globalizated and even more stronger competion, the obtention of sustenable competitive advantages becomes fundamental, thus the strategic elements must be aggregated with cost information. With the arrival of globalization, comes a new way to see the firm's environment and to operate inside it. The concepts of dinamism, competitive advantage, core competences, make possible new structures, for example, the cooperation networks called virtual organizations, and they are answers to the new managemant challenges. The organizations with tecnology basis, just their agility, have a profile to actuate in virtual organizations. The concept of strategie, specially the one related with costs, is coming by the globalization too. The aplication of Strategic Cost Managemant (SCM) and their instruments is associated with all of the organization's activities, specially, the one related with cost managemant. It's convenient study and discuss the operation rules of a strategic cost managemant model and the possibilities of aplication in virtual organizations.

Keywords: strategic cost managemant, virtual organization, competitive advantages. 


\section{INTRODUÇÃO}

\subsection{Localização e Relevância do Tema}

A partir dos anos 80 e de forma mais intensa ao final da Guerra Fria (início da década

de 90), surge uma série de transformações econômicas profundas. Inicialmente no mundo ocidental desenvolvido (mas com reflexos nos demais países), começam a ser delineados, uma nova sociedade, uma nova economia e por conseguinte uma nova dinâmica empresarial. A situação anterior, caracterizada pela existência de organizações atuando através de processos produtivos mais simplificados, baixa tecnologia e uso intensivo de mão de obra, dá lugar à uma nova realidade muito mais dinâmica e definida dentro de uma competição acirrada e globalizada.

Uma nova sociedade ocidental, denominada por DRUCKER (1993) de "PósCapitalista" (DRUKER, 1993, p. 11) passa a funcionar sob o padrão global e sob a égide de uma civilização mundial. Uma marca fundamental deste novo arranjo se constitui na velocidade de difusão das informações e inovações, bem como o funcionamento com base em organizações e cujo principal recurso passa a ser o conhecimento. A velocidade de difusão das informações e dados através da informática e das telecomunicações e as inovações tecnológicas e organizacionais, estão relacionadas com a chamada globalização econômica dos mercados e das relações sociais e econômicas onde "as fronteiras nacionais e o Estado-nação perdem sua importância econômica e os conceitos de soberania nacional estão sendo redefinidos“ (NAKANO, 1994, p. 8).

A globalização econômica passa a gerar também uma revolução empresarial baseada na tecnologia avançada, na organização flexível e enxuta e na competição intensa em perspectiva mundial, sendo que todos os aspectos relacionados com a gestão e o planejamento das empresas começam a sofrer mudanças radicais, mudanças estas que impõem uma série de desafios aos administradores da empresa do final do século. A administração estratégica definida como um "processo contínuo e interativo que visa manter uma organização como um conjunto apropriadamente integrado ao seu ambiente " (CERTO \& PETER, 1993, p. 6), passa a ser uma área crítica dentro do processo administrativo com 
grande importância na condução de organizações bem sucedidas e na superação por parte destas organizações dos novos desafios impostos pela globalização.

Um dos maiores desafios empresariais do mundo globalizado diz respeito justamente a questão da concorrência no contexto global, onde o fator competitividade passa a ser encarado com maior ênfase. O acirramento da concorrência entre as organizações (grandes e pequenas), trazido pela globalização, acarreta a necessidade de se praticar o planejamento estratégico com uma nova perspectiva de competitividade (estratégias concorrenciais). Torna-se vital para a sobrevivência das empresas, e para a sua inserção no mundo globalizado, a definição de como elas podem competir com maior eficácia para fortalecer sua posição no mercado perante seus concorrentes. Este objetivo pode ser atingido tendo em vista novas dimensões e conceitos empresariais e, no que concerne a esse trabalho, podem ser destacados três destes conceitos: Vantagem Competitiva, desenvolvido por PORTER (1992), Competências Fundamentais ou Essenciais (Core Competences), conceito introduzido a partir de 1994 por HAMEL\&PRAHALAD (1994) e descrito em GOLDMAN; NAGEL; PREISS, no livro Agile Competitors (1993).

Como respostas aos novos desafios, as empresas passam a adotar esquemas de integração e parcerias, constituindo verdadeiras redes de cooperação global, caracterizadas pela sua grande competitividade e dinamismo. Certas redes de cooperação são denominadas Empresas Virtuais. As Empresas Virtuais, seriam redes horizontais de empresas que se reuniriam em caráter temporário e onde estas empresas possuiriam a competência para a execução de parte de um processo. As Empresas Virtuais também são assim definidas devido ao fato de não estarem necessariamente ligadas por uma localização geográfica comum, mas sim espalhadas em diversos lugares e atuando de forma coordenada por meio de um sistema de comunicação que os avanços tecnológicos nos campos das telecomunicações e da informática lhes possibilita.

A atuação baseada em Empresa Virtual tem produzido efeitos competitivos arrasadores sobre as grandes empresas que permanecem verticalizadas. Não bastam mais escala de produção, domínio da tecnologia produtiva, especialização e disciplina com preparo de recursos humanos. Contam também a flexibilidade da empresa, sua gestão de fatores não diretamente ligados a produção (fatores estratégicos), e a capacitação de seus funcionários 
para a resolução de problemas, trabalho em grupo e ação e pensamento estratégicos. Diante deste quadro, as organizações passam a buscar a competitividade com agilidade e flexibilidade, menos níveis hierárquicos, maior especialização, organizando-se em redes de fornecedores, de clientes, de produção e pesquisa tecnológica em nível nacional e global.

O fato de as empresas passarem a interagir entre si sob a forma de Empresa Virtual possibilita vantagens competitivas em relação as empresas isoladas mas também pressupõe um novo conjunto de variáveis a serem consideradas. Estas variáveis levam a um cenário onde se fazem necessários novos conceitos em termos de gestão empresarial para que este novo modelo de negócio produza os resultados desejados.

Surge a necessidade de se inserir o uso estratégico nas informações de custos e na determinação de ganhos, relacionando estas informações com uma estratégia de gestão afinada com as novas exigências de um mundo mais competitivo, pois além de mais competitivo, o novo mundo empresarial traz consigo novas formas de atuação que exigem das empresas dinamismo, agilidade, capacidade de cooperação e uso intensivo de tecnologia .

O enfoque estratégico da gestão de custos, introduzido em 1993 pelos Profs. J. K. SHANK e V. GOVINDARAJAN (Amos Tuck School / Dartmouth College) se constitui em uma primeira estrutura analítica para se relacionar a informação contábil de custos com a estratégia gerêncial de uma empresa. É uma forma não tradicional de se encarar a gestão de custos e que vem de encontro com as novas exigências do processo de globalização, da evolução tecnológica e das mudanças que estes fatores operam no ambiente empresarial. Para estes autores a Gestão Estratégica de Custos realizada através de três ferramentas básicas, Análise de Cadeia de Valores, Análise de Direcionadores de Custos e Análise de Posicionamento Estratégico.

A Gestão Estratégica de Custos - Strategic Cost Managemant (SCM), vem então suprir a contabilidade de custos tradicional na sua deficiência em produzir informações de custos para tomada de decisões dentro de um contexto externo à empresa, onde sejam levadas em consideração a posição competitiva e as condicionantes estratégicas da mesma e não apenas uma posição de custos e margens. A competitividade empresarial no ambiente globalizado passa a se tornar um fator de sucesso e sobrevivência, possuindo aspectos 
internos e externos que devem ser levados em consideração. Novas dimensões são colocadas como a busca da qualidade e de produtos variados e customizados a preços competitivos, entregues com rapidez e flexibilidade A análise de custos tradicional está direcionada para os aspectos internos apenas e isto por si só não garante, e não informa, portanto não suporta a decisão no que tange a competitividade e vantagens competitivas duradouras. É necessário agregar o componente externo na análise e na gestão empresariais e é precisamente isto que o SCM procura desenvolver.

Então, as exigências de competitividade e de informações para tomadas de decisões precisas, necessárias às empresas individuais também se fazem presentes nas Empresas Virtuais e parece ser oportuno colocar o SCM sob a ótica de Empresas Virtuais, procurando oferecer um ferramental analítico que lhes possibilite atuar de forma competitiva, não apenas calculando e medindo custos mas gerindo estes com vistas a incrementar a competitividade.

\subsection{Objetivos}

O presente trabalho se propõe apresentar um estudo teórico e realizar uma análise sistemática da adequação da Gestão Estratégica de Custos na criação e gerência de Empresas Virtuais visando definir as potencialidades e deficiências do mesmo. Principalmente com relação a seus seis processos básicos de negócio referenciados acima, tem-se a preocupação em inferir se o SCM e suas ferramentas, tal como são preconizadas em SHANK \& GOVINDARAJAN (1993) (a cadeia de valores, o posicionamento estratégico e os direcionadores estratégicos de custos) guardam uma possibilidade real de aplicabilidade para a forma de Empresa Virtual.

Tendo em vista a possibilidade de atuação empresarial sob a forma de Empresas Virtuais, realizar um cruzamento de requisitos de processos de formação de Empresas Virtuais e das possibilidades de compatibilidade e adequação dos mesmos com as ferramentas de SCM. 


\subsection{Metodologia e Estrutura do Trabalho}

A metodologia consta de cinco etapas descritas a seguir:

a) Revisão Bibliográfica: Globalização, Competitividade, Dinamismo, Novas Tendências Estratégicas (vantagem competitiva, competências essenciais, concorrência dinâmica, etc.), Gestão de Custos, Custo por Atividades, Visão Microecômica, Custos de Transação.

b) Definição/Sistematização de Critérios de Gestão Estratégica de Custos e de Empresas Virtuais: Desenvolvimento e consolidação de conceitos a cerca destes dois temas.

c) Compatibilidade/Adequação: Seleção de combinações Processos de EvsFerramentas de SCM que oferecem maiores possibilidades de aplicabilidade prática: Decisão sobre as melhores formas de custeio estratégico e de sua relevância para os processos que constituem as Evs, com relação a aspectos de padronização, facilidade, desempenho, qualidade de informações.

d) Definição e escolha das possibilidades de utilização do SCM com relação aos diversos processos que formam as Evs e uma proposta de um sistema de Gestão Estratégica de Custos: Definindo detalhes do sistema em termos teóricos e práticos, implementação, capacitação das empresas.

e) Conclusões e sugestões de trabalhos futuros.

A estrutura do trabalho estará organizada da seguinte maneira: No Capítulo 2 tem-se uma revisão de literatura onde são abordados conceitos pertinentes ao trabalho e que se constituem na base de formação do contexto no qual se desenvolveram a Gestão Estratégica de Custos e as Empresas Virtuais, tais como globalização, competitividade, dinamismo, tecnologia, estratégia competitiva, vantagem competitiva, competências essenciais, cooperação entre empresas, aspectos microeconômicos (custos de transação) e gestão de custos (revisão de conceitos). 
O Capítulo 3 se divide em duas partes. Na primeira é feita uma sistematização dos critérios que estabelece os parâmetros gerais do que se deverá entender neste trabalho por Empresas Virtuais e seus processos constitutivos de um lado e de outro a Gestão Estratégica de Custos e suas ferramentas de análise.

No primeiro caso, a definição dos critérios de Empresas Virtuais começa revendo-se as concepções relativas à este tema encontradas na nova percepção de concorrência e gestão denominada de dinamismo e representada neste trabalho através da contribuição de GOLDMAN; NAGEL; PREISS. (1995). Nesta seção então serão abordados a cooperação e sua pertinência para as Empresas Virtuais, as vantagens e razões para as empresas se reunirem sob este novo arranjo. São colocadas também as seis razões estratégicas para se utilizar do conceito de Empresa Virtual e um conceito subjacente a este denominado de Teia Virtual. Após esta etapa, tem-se a definição e detalhamento dos processos ou estágios nos quais se divide a Empresa Virtual tal como é apresentado na contribuição de GORANSOM (1995).

No que tange a Gestão Estratégica de Custos (SCM) - , é feita uma descrição retirada das contribuições encontradas em SHANK E GOVINDARAJAN (1993), das três ferramentas básicas do SCM, a saber: Cadeia de Valores, Posicionamento Estratégico e Direcionadores Estratégicos de Custos.

Após esta primeira parte, inicia-se uma segunda dedicada às análises de compatibilidade e adequação entre as ferramentas SCM e os processos de Empresas Virtuais através de matrizes entre os dois fatores tanto para a adequação como para a compatibilidade.

Por fim, com base nas análises de adequação e compatibilidade serão extraídas algumas conclusões (Capítulo 4) a cerca das melhores combinações de fatores e sugestões para futuros trabalhos sobre o tema. 


\section{REVISÃO DE LITERATURA}

\subsection{Contexto Global}

\subsubsection{A Globalização e seus Efeitos}

A globalização se constitui em um processo de transição e de transformação deste fim de século que está modificando profundamente a estrutura de funcionamento da sociedade capitalista. Existem várias dimensões da globalização pelas quais ela se manifesta tais como a dimensão financeira, produtiva, institucional, política e cultural. Um reflexo importante da globalização e que merece uma análise mais atenta é o relativo às modificações que estão ocorrendo nas empresas como resposta ao novo ambiente globalizado. Os novos conceitos gerenciais que vêm surgido se constituem em uma autêntica revolução empresarial com diferenças profundas em relação às formas tradicionais de administração.

O contexto mundial dos anos 90 apresenta características marcantes em termos de novas formas de produção e concorrência. Fruto de transformações importantes ao longo de décadas anteriores (anos 70/80), estas transformações alteraram e vêm alterando profundamente as tradicionais relações econômicas, sociais, políticas e culturais estabelecidas pelo sistema capitalista mundial e que vigoraram até aproximadamente os anos 60 e início dos anos setenta. A estes processos recentes de mudança convencionou-se conceituá-los em um único macroprocesso e atribuir ao mesmo a denominação de globalização.

Diversos estudiosos do tema globalização tem sido de certa forma unânimes em afirmar que, a partir deste fenômeno, as relações de amplitude macro entre estado, economia e sociedade se transformam e produzem efeitos revolucionários sobre a amplitude micro das 
empresas do sistema capitalista, sendo que estes efeitos e sua evolução começam a se fazer presentes ainda neste final de século. Da mesma forma que se tem um novo sistema sócioeconômico, tem-se uma nova empresa funcionando com premissas de gestão diversas das tradicionais.

A partir do relato comparativo das contribuições de determinados estudiosos do fenômeno da globalização, surgem algumas conclusões preliminares a cerca dos efeitos deste processo sobre a economia capitalista e sobre a dinâmica empresarial. Entende-se que as ciências econômicas são das que mais tem se dedicado em estudar, discutir e analisar de forma mais explícita e organizada o fenômeno da globalização e seus efeitos sobre as nações e o mundo empresarial. Portanto julga-se importante levantar e acrescentar a visão que alguns pensadores nacionais têm deste processo que se originou na esfera do mundo desenvolvido e hoje, de uma forma ou de outra, acaba afetando a realidade de países em desenvolvimento como o Brasil. Para isto foi feita uma pesquisa e uma leitura em periódicos recentes especializados em ciência econômica destacando-se alguns artigos, opiniões , entrevistas e obras, numa tentativa de expor o pensamento destes pesquisadores - alguns deles economistas brasileiros - de maneira coordenada sob o ponto de vista histórico e lógico.

O fenômeno da globalização é definido por estudiosos em economia e relações internacionais como um processo iniciado nos anos setenta, que se acentuou em meados da década de 80, ganhando novo impulso, segundo CASTRO (1995), com o fim da guerra fria (inaugurado pela queda do muro de Berlim em 1989). A globalização inicia uma nova fase do sistema capitalista, fase esta caracterizada por um conjunto de alterações e transformações sócio-econômicas. Também definida como um processo amplo e independente gerado pelos desenvolvimentos tecnológicos das últimas três décadas, a globalização se constitui em um "macroprocesso de internacionalização das relações econômicas, culturais, políticas e dos mercados em geral" (ZINI, 1996, p. 12), eliminando as barreiras que separavam os indivíduos, os produtos e os fluxos de dinheiro. Com a profunda restruturação na ordem produtiva do sistema capitalista gerada pela globalização (e que ainda se encontra em andamento), tem-se um sistema funcionando de acordo com a lógica da integração mundial de produtos e mercados e com a internacionalização e desregulamentação destes mesmos mercados, sempre acompanhada de uma onda de renovação tecnológica que passa a ser permanente. 
A origem do processo de globalização, já situada no tempo, é uma decorrência dos desenvolvimentos tecnológicos iniciados a partir dos anos 70/80 nos campos da informática, das telecomunicações e da microeletrônica, desenvolvimentos estes que continuam ocorrendo em processo contínuo e, tudo indica, permanente. Estes fatores constituíram-se em uma autêntica revolução tecnológica (que chegou a ser chamada de terceira revolução industrial), caracterizada pela disseminação ampla do uso de computadores, grande velocidade no processamento de dados e no deslocamento das informações (ambos em amplitude mundial e a custos decrescentes) e produção de bens com base em processos cada vez mais baseados em automação e microeletrônica. Para NAKANO (1994), existe uma derivação destas evoluções tecnológicas e que posteriormente se juntaria a elas intensificando e ampliando ainda mais os efeitos da globalização: a evolução e disseminação de conceitos gerenciais gerados no Japão, baseados na produção enxuta e flexível e em premissas como aperfeiçoamento contínuo, minimização de erros e desperdícios, qualidade total, cooperação, autodisciplina e relações produtivas horizontais (desverticalização e terceirização da produção).

Já em COUTINHO (1992), se pode identificar com mais propriedade as origens do desenvolvimento tecnológico que detonou a globalização. A questão das inovações tecnológicas e sua relação com o processo de globalização é tratada em uma abordagem um pouco mas aprofundada. Esta abordagem destaca a existência de um processo inicial de inovação que veio gerar um sistema produtivo denominado pelo autor de complexo eletrônico. Este complexo teria se viabilizado nas economias capitalistas mais desenvolvidas com o advento da microeletrônica associada a tecnologia da informação, e sua disseminação em diversos estágios produtivos e atividades econômicas e destaca-se como fator fundamental para esta disseminação, a diminuição generalizada dos preços de bens e insumos deste segmento proporcionada por uma grande e rápida queda no custo de processamento (bit/U\$) através da produção em grande escala de chips cada vez mais poderosos e mais baratos. Cria-se uma base técnica que gera um novo mundo produtivo cujos setores mais dinâmicos estão localizados em indústrias e segmentos relacionadas a computação, telecomunicações, automação e eletrônica de consumo. A partir da consolidação das bases tecnológicas do complexo eletrônico se verifica um conjunto de tendências, algumas das quais já mencionadas como novas estruturas, estratégias empresariais e processos de trabalho, automação, 
produção flexível e microletrônica. Dentre estas tendências se tem "a globalização como um aprofundamento da internacionalização “ (COUTINHO, 1992, 81), que se verifica nos anos 80. COUTINHO (1992) destaca como principias manifestações da globalização: a interdependência e conexão global de mercados financeiros e investimentos produtivos, a formação de oligopólios mundiais competindo em escala global (a exemplo da indústria automotiva) e as redes globais de comunicação e produção baseadas em telecomunicações no âmbito das grandes empresas.

A condição relativa aos efeitos dos avanços tecnológicos em informática e telecomunicações sobre os mercados financeiros e de capitais tem sido considerada uma das mais importantes para se entender a globalização devido ao seu poder no que tange ao próprio fenômeno da globalização. A liberalização e desregulamentação dos mercados financeiros, também chamada de globalização financeira, fez com que os mercados (inicialmente a partir dos países industrializados), aproveitando-se do barateamento dos custos de comunicação, das novas tecnologia de transmissão, processamento e armazenamento de informações e dados e do progresso das telecomunicações via satélite, se conectassem entre si realizando transações cujo volume e velocidade transcendem as barreiras de tempo e espaço que anteriormente existiam.

O aumento do volume e da velocidade de circulação de recursos financeiros em nível mundial, através de novos operadores e agentes de mercado como os fundos de pensão, trouxe em si além de um potencial de desenvolvimento econômico enorme devido a otimização da alocação de recursos financeiros, também implícito um risco de crises de curto prazo mas de alcance profundo, devido a instabilidade destes recursos, seu caráter especulativo e a dificuldade dos bancos centrais em controlar os fluxos destes capitais (vide o caso das crise financeiras do México em 1994, as desvalorizações especulativas contra as moedas de vários países desenvolvidos na década de 90, a quebra do banco Barings e os ataques especulativos às moedas das economias do sudeste asiático em 1997). É observado em RONDINO (1996) que o controle do fluxo anual de capitais (U\$ 800 bilhões nos anos 90 e com crescimento de $10 \%$ ao ano), se constitui em um dos pontos principais a serem considerados na análise do processo de transformações na economia denominado globalização. 
Tem-se então que, dentro da faceta financeira da globalização, a facilidade, rapidez e agilidade com que os fluxos de recursos estão se movimentando através das fronteiras, tem desafiado os mecanismos tradicionais de controle de mercado. Com isto os sistemas financeiros nacionais vão se tornando vulneráveis pois, diante da rapidez e agilidade das operações, as entidades estatais que os administram - os Bancos Centrais - vão perdendo seu controle sobre o mercado. O aumento da amplitude geográfica de atuação dos bancos, as operações extremamente voláteis de papeis especulativos denominadas derivativos e a ausência de mecanismos de prevenção contra crises geradas por estas operações são fatores a serem considerados neste processo.

O fenômeno da globalização, segundo BAUMAN (1996) se abre em várias faces ou enfoques: além do enfoque financeiro já descrito, tem-se inicialmente o enfoque comercial onde ocorre a abertura das economias acompanhada de um crescimento do comercio mundial e o fato de várias economias anteriormente fechadas e isoladas passarem a se inserir e participar deste comercio mundial. No aspecto produtivo se ressalta a modificação na forma de produção com um aumento da participação das empresas multinacionais nas transações de comercio internacional e uma transferência de plantas produtivas destas organizações de seus países de origem para países em desenvolvimento onde a mão de obra é mais barata, (numa busca pelo aumento de competitividade via diminuição de custos) ou mesmo para outras países industrializadas (visando por motivos de ordem estratégica, complementar a produção).

Também de acordo com BAUMAN (1996), esta produção mundial que ultrapassa as fronteiras nacionais, acaba transcendendo as políticas econômicas locais implementadas pelos estados. A lógica passa a ser a empresarial a nível mundial e não mais governamental a nível doméstico. Os interesses nacionais e a administração da sociedade nacional se interpõem e chegam a se submeter a dinâmica produtiva internacional visando a geração de empregos e investimentos bem como os produtos e a tecnologia mais avançados, trazidos pelas empresas transnacionais. Esta constatação de perda de espaço e poder dos estados na formulação e implementação de suas políticas econômicas e na condução do destino das pessoas e empresas também é observado por CASTRO (1995), onde a diminuição da relevância do papel do estado-nação e dos partidos políticos se reflete por exemplo, no fato de os bancos centrais destes estados - mesmo nos países considerados avançados - serem hoje impotentes 
para controlar ataques especulativas contra suas moedas (vide os exemplos já mencionados das crises do México em 94, da desvalorização do iene em 95/96, a quebra do Banco inglês Barings ). Para ZINI (1996) este processo chega a afetar e transformar o entendimento do que venha a ser o conceito de soberania nacional, num processo irreversível e inevitável.

Chega-se assim ao enfoque institucional referido em BAUMAM (1996), onde o conceito e o papel de estado-nação como um incentivador de determinados setores econômicos, se modifica e seus instrumentos tradicionais de intervenção perdem sentido. A orientação recomendável do estado na era da globalização passa a ser proporcionar condições de competitividade e inserção no mercado internacional (sobretudo c/ atuação em educação, saúde e pesquisa tecnológica) e regular as normas gerais de funcionamento da economia. A visão de BAUMAM (1996) vem de encontro e referenda as conclusões de DRUCKER (1994) sobre este assunto onde descreve com propriedade a redefinição do papel do Estado e destaca a necessidade premente de reformulação do estado nacional, inovando suas relações com os outros governos e organizações internacionais (públicas e privadas) e aumentando a sua eficácia interna.

Já em NAKANO (1994), existe esta mesma divisão do processo de globalização baseada em várias dimensões - dimensão financeira, comercial, produtiva e institucional contudo, os enfoques são colocados de maneira a sugerir uma relação de causa e efeito ou no mínimo de encadeamento lógico entre os mesmos. A globalização deve ser encarada como um processo derivado do inter-relacionamento destes enfoques. Assim, na visão deste autor, tem-se na verdade dois processos iniciais: a globalização dos mercados sendo acompanhada e amparada pelas inovações tecnológicas e organizacionais. Gera-se inicialmente um cenário no qual ocorre a internacionalização do crescimento econômico, da produção e dos mercados que começa a ocorrer na economia mundial logo após o fim da segunda guerra, fazendo com que os fluxos de comércio cresçam a taxas sem precedentes. As economias tornam-se mais abertas, deixando de constituir barreiras ao fluxo de bens e serviços. Com este aumento de comércio mundial, as empresas aumentam o seu grau de internacionalização intensificando o fluxo de investimentos produtivos. Com isto também o mercado de capitais se internacionaliza mediante um rápido crescimento de volume de fluxos financeiros. Esta internacionalização generalizada provoca uma interdependência crescente 
entre os estados nacionais, sendo que o cenário externo passa a ser um fator de influência na formulação das políticas públicas e nas estratégias das empresas.

Ainda para NAKANO (1994), acompanhando este processo generalizado de internacionalização produtiva, financeira e comercial, tem-se na década de 80 a ocorrência de mudanças tecnológicas e inovações organizacionais relacionadas. As mudanças tecnológicas estariam evidenciadas na alteração de toda a estrutura produtiva e de gestão, no desenho e comercialização de bens e serviços provocada de um lado pela revolução na microeletrônica produzindo novas tecnologia de computação, telecomunicações, informação e na mecânica de precisão, gerados nos EUA e de outro lado nos novos conceitos de organização enxuta e flexível originados no Japão. Isto produziu reflexos além das estruturas produtivas, também nas estruturas organizacionais e no próprio comportamento humano. Com a revolução eletrônica (também chamada de terceira revolução industrial), ocorre a difusão rápida e a custos decrescentes da utilização de computadores em todos os estágios produtivos e administrativos das empresas, tornando possível a introdução e intensificação das inovações organizacionais e de gestão já mencionadas. As plantas e equipamentos passam a ter múltiplas funções com produção enxuta, flexível variada e customizada, onde a escala não é mais um fator competitivo fundamental no custo de produção.

Em termos de consequências trazidas pelo processo de globalização tem-se, segundo CASTRO (1995), consequências benéficas, como por exemplo o progresso técnico em si em todos os níveis e a redução constante de preços de bens em nível mundial e macroeconômico, o que propicia acesso generalizado e facilitado a estes bens mas também consequências maléficas como a exclusão social, uma distribuição de renda desigual (também a nível mundial) e uma instabilidade financeira e econômica potencialmente crônica. O capitalismo se internacionaliza sobre novas bases, sem fronteiras nacionais e buscando uma renovação tecnológica constante e por vezes perversa (vide os efeitos sobre a geração de empregos) mas imprescindível e inevitável. As consequências sociais delicadas do processo de globalização são também observadas em RONDINO (1996), onde foi destacado o aspecto desigual em que este processo ocorre em termos de velocidade e benefícios. Isso significa que a globalização e o desenvolvimento economico-social que a acompanha traz em si um potencial de exclusão de países mais pobres com importantes consequências sociais sobre estas sociedades. 
Outra conseqüência apontada por ZINI (1996) é a regionalização da economia. Paralelo e assessório a globalização e, segundo NAKANO (1994) como uma forma de resposta dos estados contra o seu enfraquecimento gerado pelos efeitos da globalização, ocorrem processos de regionalização (Mercosul, Mercado Comum Europeu, etc.), iniciativas de estados-nação próximos em termos geográficos, no sentido de se criar mercados comuns, blocos econômicos com liberalização de tarifas e eliminação de restrições quanto a circulação de mercadorias pessoas e capitais de um mesmo bloco.

Por fim, destaca-se uma conseqüência importante e com reflexos sobre a nova dinâmica empresarial tem a ver com uma das conclusões tiradas na CONFERÊNCIA: “GLOBALIZAÇÃO: O QUE É E SUAS IMPLICAÇÕES “ (1996), onde tem-se ao mesmo tempo uma homogeneização e uma diversificação do processo produtivo capitalista também denominado massificação customizada : a produção de bens e serviços se massifica em escala mundial porém individualizando e personalizando os produtos de acordo com as necessidades com cada cliente, ou seja, produtos massificados mundialmente mas com opções diversificadas oferecidas aos clientes mundiais.

Resta tecer algumas considerações mais orientadas em direção da dimensão política, social e cultural da globalização. Em que pese o fato de que os efeitos sociais da globalização serão descritos no item seguinte, é interessante relacionar também estes efeitos aqui além dos já mencionados efeitos políticos e culturais. Então, na tentativa de ampliar um pouco mais o horizonte desta descrição da globalização até agora mais restrito à esfera econômica e de negócios, recorre-se às contribuições de KUMAR (1997)

De modo mais geral as mudanças políticas e culturais são caracterizadas por KUMAR (1997) de forma até certo ponto independente do próprio processo de globalização. Com origem logo no início da década de setenta, este autor, utilizando-se de observações de outras obras e discursos pertinentes ao tema, descreve uma situação onde se constata uma incapacidade da sociedade capitalista ocidental em distribuir os ganhos obtidos com o crescimento econômico e um fortalecimento de teses liberais, exploradas por partidos de direita, e que defendem a volta da liberdade de mercado e o fim da intervenção do Estado na economia. 
Um novo parâmetro de espaço-tempo, caracterizado por “...bancos 24 horas, faturamento automático nas caixas de supermercados, desaparecimento de cheques e dinheiro, processadores de texto e máquinas fax, reservas de hotéis e passagens aéreas online, transmissão via satélite de qualquer parte do mundo" e uma " sociedade centralizada no lar (compras via computador, trabalho em casa, educação a distância)”, (KUMAR, 1997, p. 27) trazem um novo estilo de vida modificado pela revolução da informação e pela globalização.

Com relação aos aspectos denominados por $\operatorname{KUMAR}(1997$, p. 132,127,64) de “relações políticas e industriais", este autor lista a seguinte relação de aspectos importantes:

- Fragmentação de classes sociais.

- Declínio de partidos políticos nacionais baseados em classe e em votação de acordo com a classe

- Surgimento de movimentos e redes sociais baseados em região, raça, sexo ou política de assunto único ( ex; movimento antinuclear, feminista e ecológico).

- Movimentos periféricos sub e supranacionais

- Declínio de sindicatos de categorias inteiras e de negociações salariais centralizadas e ascenção de negociações localizadas.

- Fim do compromisso do corporativismo com a classe

- Força de trabalho dividida entre núcleo e periferia

- O esfacelamento da provisão de benefícios padronizados, coletivistas da previdência social

- Aumento das opções do consumidor

- Fornecimento privado de benefícios sociais.

- Acompanhando a globalização, uma valorização de aspectos locais, nacionalismos regionais e étnicos e movimentos de cunho religioso (fundamentalismo evangélico e islâmico)

- Crise de regimes políticos baseados em premissas de esquerda (queda dos regimes comunistas) 
Na sequência, seguem os itens relativos a cultura sociedade e ideologia elencados por KUMAR (1997)

- Desenvolvimento e promoção de modos de pensamento e comportamento individualistas

- Cultura da livre iniciativa e do individualismo

- Fim do universalismo e da padronização na educação, com o aumento do sistema modular e da escolha por aluno e pais

- Fragmentação em pluralismo valores e estilos de vida

- Ecletismo pós modernista e enfoques populistas da cultura

- Privatização da vida doméstica e das atividades de lazer

- Crescente importância e influencia dos meios de comunicação de massa

- Criação e manipulação de novas realidades pela mídia

- Declínio mundial do marxismo como ideologia

- Desintegração da forma familiar tradicional, dando lugar a novos arranjos individualizados

- Sociedade centrada no lar - entretenimento (video, canais a cabo), compras ( pala TV ou internet) administração doméstica (serviços de "homebanking", alimentação (entregas a domicílio), e trabalho (estações de trabalho domésticas conectadas com a matriz)

KUMAR (1997) ressalta que em termos políticos ocorre um avanço dos conceitos defendidos por setores de direita e razão para isto é que os mesmos teriam sabido até agora se aproveitar melhor que a esquerda das mudanças trazidas pelos novos tempos e obtido com isto vitórias eleitorais expressivas. Assim sendo, o estado mais assistencialista e presente na economia dá lugar ao conceito de estado mínimo ou ao menos ótimo. KUMAR (1997) também observa que a política e a cultura passam a seguir as condições da globalização na medida em que "a globalização ergue a política e a cultura acima do nível provinciano da nação-estado e sugere novas conexões e interdependências entre os povos do mundo “, (KUMAR, 1997, p. 65) e como prova disto destaca as "alianças entre os movimentos do Primeiro, Segundo e Terceiro Mundos em uma medida impossível nas fases anteriores do capitalismo" (KUMAR, 1997 p. 65). 
Mais específicamente sobre a questão sócio-cultural, o que se depreende em KUMAR são algumas idéias básicas centradas em um novo papel da cultura na sociedade caracterizado por uma grande aderência com os aspectos econômicos. De outro lado são destacados aspectos como a "fragmentação das culturas e comunidades de classe trabalhadora, a descentralização das cidades e dos movimentos sociais e o ressurgimento do individualismo" (KUMAR, 1997, p. 127). O autor também destaca a ascenção de uma nova classe típica da era atual - os yupies - cuja realidade é baseada na mídia e voltadas para aspectos ligados com a educação superior, atuando em setores mais ligados aos serviços como finanças e publicidade. Esta nova classe possui sua própria cultura que, diferentemente da cultura das antigas classes, "não faz distinção entre elite e massa, entre alta e baixa"(KUMAR, 1997, p. 127 ).

$\mathrm{O}$ autor detaca ainda mais três aspectos culturais característicos da nova era. $\mathrm{O}$ primeiro estaria ligado a determinação e predominância da estética sobre outras esferas culturais tais como a teórica e a moral - política. No segundo aspecto, a dimensão social passa sofrer a influencia da cultura de tal forma que " as distinções sociais,...., dependem cada vez mais não do poder econômico ou político mas exibição de símbolos culturais" (KUMAR, 1997, p. 128). O terceiro aspecto diz respeito a crescente relação entre o cultural e o econômico, a exemplo disto se vê eventos culturais utilizados para a promoção de empresas, fazendo parte de toda uma tática de marketing, a cultura se torna um negócio e uma mercadoria - "Cultura não é mais simplesmente um adjunto à atividade séria de ganhar a vida, mas em grande parte tornou-se esta atividade. Grande quantidade de pessoas trabalham nas indústrias da cultura e, nos seus momentos de folga, também consomem seus produtos." (KUMAR, 1997, p. 194).

\subsubsection{Mudanças na Sociedade}

Importantes derivações a nível de sociedade surgem associadas ao advento da globalização. Estas transformações (algumas delas podem inclusive ser consideradas como fatores geradores da globalização) são descritas com propriedade, no livro de PETER DRUCKER “A Sociedade Pós - Capitalista “, de 1994. Esta contribuição de DRUCKER é colocada a seguir, devidamente cotejada com a visão de KUMAR (1997) em sua "Da 
Sociedade Pós Industrial à Pós Moderna”, mais específicamente na seção onde o autor trata das teorias ligadas à Sociedade da Informação.

O ponto de partida na visão de DRUCKER (1994) é que existirá uma nova sociedade, denominada Sociedade Pós-Capitalista, e que terá como principais valores/fatores de produção, não mais o capital, a mão de obra e a terra característicos da sociedade capitalista tradicional, mas sim o conhecimento. O conhecimento será, após a consolidação desta era, o principal fator produtivo.

A abordagem de DRUCKER (1994) divide-se em três grandes campos de análise, ou áreas, onde as mudanças estariam ocorrendo mais nitidamente: Sociedade, Política (forma de governo) e Conhecimento. Para cada área são desenvolvidos uma série de análises pertinentes que caracterizam o quadro de transição do sistema em torno do qual se organizará uma nova sociedade Pós Capitalista e cujo principal recurso econômico e produtivo é o conhecimento.

\section{a) Evolução Histórica do Conhecimento}

Dentro do tema sociedade, surge um raciocínio inicial que procura caracterizar a transformação da sociedade capitalista em um tipo de sociedade diverso denominado sociedade do conhecimento. Inicialmente tem-se a constatação, após a II Grande Guerra, de que a sociedade ocidental passou a viver sob a égide de uma civilização mundial caracterizada pela velocidade da difusão das informações e inovações e com um alcance/caráter predominantemente globalizado de suas relações socio-econômicas.

Após a revolução industrial dos séculos XVIII e XIX, o conhecimento deixa de ter o significado de auto-conhecimento ou aptidão, oriundo da cultura helênica para assumir um significado de "saber fazer" que, associado ao novo conceito denominado tecnologia (a capacidade de reprodução do como fazer em grande escala sem restrições de aptidão), passou a gerar uma situação na qual qualquer um poderia aprender a fazer uma tarefa e/ou operar uma máquina. É nesta diferenciação do tratamento do conhecimento que reside a gênese do capitalismo em sua fase inicial, segundo DRUCKER (1994). 
Enquanto que antes da revolução industrial e do nascimento do capitalismo, o conhecimento se definia como um bem privado e exclusivo ligado ao verbo "ser", agora se transformava em bem público ligado ao verbo "fazer " ou ainda a palavra ferramenta. Mas esta massificação do conhecimento e da tecnologia cuja velocidade de difusão e alcance global proporcionaram através da revolução industrial o nascimento do capitalismo em escala mundial, ainda não se constitui na principal contribuição de DRUCKER (1994), mas sim a seqüência histórica que ele dá à esta evolução. É esta seqüência, aliás que passa a explicar o porque da não derrocada do capitalismo como previam Marx e seus seguidores já naquela época.

O capitalismo foi gerado pela revolução industrial, como um sistema produtivo baseado em máquinas (manufatura) e duas novas classes sociais - capitalistas e proletários -. Através de fusões de capitais que geravam excessivas concentrações que por sua vez alienavam a classe trabalhadora do processo produtivo, o sistema capitalista estaria caminhando para um situação contraditória, que na visão marxista redundaria necessariamente em ruptura do sistema. Isto realmente poderia acontecer se não fosse o advento de uma nova revolução que surge por volta do começo do século XX e é denominada por DRUCKER de "Revolução da Produtividade", (DRUCKER, 1994, p. 14).

Esta revolução, que tem sua origem no estudo e racionalização do trabalho desenvolvido por Taylor, vem anular a guerra de classes e as contradições do capitalismo com a sua inerente possibilidade de indigência e alienação da classe trabalhadora e conseqüente ruptura do sistema .

Um dos fatores diferenciadores entre as duas revoluções, é a passagem da utilização da tecnologia como o conhecimento aplicado à máquinas e ferramentas (processos e produtos) para o conhecimento aplicado ao estudo do trabalho e à sua otimização. Segundo DRUKER (1994), a contribuição de Taylor foi exatamente reduzir o trabalho a tarefas e movimentos repetitivos simples executados da melhor maneira possível, sendo que uma vez dissecada a fórmula de sua utilização, seriam passíveis de disseminação para qualquer ser humano normal através do treinamento. A utilização deste novo conceito acabou por desarmar a contradição capitalista pois o aumento da produção por trabalhador (aumento da 
produtividade) - que a disseminação mais rápida do trabalho através do treinamento proporcionou - fez aumentar a riqueza e consequentemente os salários e o padrão de vida. Surge então uma situação na qual o aumento de produtividade proporciona mais tempo para os trabalhadores se dedicarem ao lazer e educação sendo que o trabalho manual começa a representar uma parcela cada vez menor do total da força de trabalho. Tem-se inclusive uma nova classe social: a classe média com uma renda e padrão de vida superiores ao proletariado e que passa a ter um papel importante na sustentação do sistema .

Contudo nos anos 80 , também a revolução da produtividade começa a apresentar sinais de esgotamento de seus benefícios, atingindo os seus limites. Vem então na visão de DRUCKER (1994) uma terceira revolução, a denominada "Revolução Gerêncial", (DRUKCER, 1994, p. 20).

Esta revolução tem como principal característica a aplicação do conhecimento ao conhecimento, e como um aspecto importante, a valorização do curso superior como forma de ascensão social. Isto significa que cada vez mais o conhecimento obtido de forma sistemática se torna um recurso chave, em detrimento dos recursos tradicionais terra, capital e mão de obra. A razão da denominação gerêncial para esta revolução é de que se passa a entender a atividade e o papel gerenciais como os fornecedores de conhecimento para se descobrir como o conhecimento existente pode ser melhor aplicado visando a obtenção de resultados, sendo que este conhecimento passa a ser aquele dirigido para a inovação sistemática ou seja para novos conhecimentos.

Esta nova conotação de gestão aplicada ao conhecimento é apontada inclusive como um dos fatores de Japão e Coréia terem dado o seu salto de modernidade, desenvolvimento e competitividade nos anos recentes. O gerente deixa então de ser apenas um chefe, mas também e principalmente um desenvolvedor de potenciais e pessoas ou ainda o "responsável pela aplicação do conhecimento e do seu desempenho", (DRUCKER, 1994, p. 23).

Estas três revoluções são colocadas sob a perspectiva da utilização do conhecimento sendo que este conhecimento se prova na ação através de informações focalizadas e geradoras de resultados. Sendo assim a experiência e o treinamento passam a contar tanto quanto ou mais do que uma instrução escolar formal ou do aprendizado, surgindo a 
necessidade crescente de especialização. É interessante observar que com esta posição DRUCKER (1994) acaba colocando em cheque algumas afirmações encontradas no discurso e na literatura gerenciais dos últimos anos nos quais o profissional do futuro e de sucesso seria um generalista, sabendo "um pouco de tudo" por assim dizer. Esta especialização e sua necessidade fica mais clara quando mais adiante se afirma que as organizações são especializadas e por conseguinte seus membros também o serão.

KUMAR, em uma visão mais crítica, ao demonstrar a sua interpretação da sociedade da informação e das diversas teorias sobre o tema que foram construídas nas últimas décadas, parte do advento da importância da informação como base para o surgimento de uma sociedade voltada para os processos ligados ao acesso, produção e distribuição da informação. $\mathrm{O}$ fator gerador desta nova realidade está vinculado aos avanços da microeleletrônica e da disseminação do uso dos computadores aliados às telecomunicações.

A partir deste processo, o autor identifica uma autêntica revolução baseada na informação e no conhecimento, cujos efeitos se comparam ao surgimento da revolução industrial. Chegam a ser comparados em termos de fatores de transformação da nova sociedade à associação energia, recursos econômicos característicos da formação da sociedade industrial.

Guardando uma certa semelhança com as abordagens sobre a globalização, KUMAR (1997) destaca que o computador somente não seria suficiente para catalizar este processo mas sim uma associação do mesmo com as telecomunicações aliando processamento de informações a sua disseminação. "A combinação de computadores satélites, televisão, telefone, cabo de fibra ótica e microcomputadores enfeixou o mundo em um sistema de unificado de conhecimento. (.......). A nova esfera de informação opera em um contexto global. O homem não tem mais necessidade de buscá-la, já que ela pode ser trazida ao lar ou ao escritório", (KUMAR, 1997, p. 22).

Para KUMAR (1997), o conhecimento de qualquer forma e a exemplo de DRUCKER se torna uma variável central para o sistema econômico e seu desenvolvimento técnico, sendo que os novos fatores a serem considerados são a informação e o conhecimento tomando o lugar do capital e trabalho do sistema capitalista tradicional, "O 
trabalho e o capital, as variáveis básicas da sociedade industrial, são substituídas pela informação e pelo conhecimento", (KUMAR, 1997, p. 24).

\section{b) Organizações}

Tem-se dentro das modificações propostas na obra de DRUCKER (1994) e relacionadas com a sociedade, um outro tema importante e que merece ser destacado, é o conceito e o papel das organizações dentro da nova sociedade do conhecimento.

Além de uma sociedade onde o principal recurso é o conhecimento, a sociedade PósCapitalista se caracteriza por ser uma sociedade estruturada através do funcionamento de organizações, e aqui o termo organização seria definido como "um grupo humano de especialistas trabalhando conjuntamente na execução de uma tarefa comum", (DRUCKER, 1994, p. 27). Mas seja qual for a tarefa, a grande função de uma organização para DRUCKER (1994) seria tornar produtivos a soma de conhecimentos existentes. As principais características de uma organização na sociedade Pós-Capitalista seriam as seguintes:

- Especialização: trata-se de uma ferramenta ajustada a sua tarefa, com uma missão clara. (ex.: uma orquestra de músicos especializados mas regidos por uma única partitura).

- Orientação para resultados: existe um fim e um resultado a ser alcançado e, na busca destes resultados, torna-se muito importante a manutenção de pessoas qualificadas dentro da organização pois na sociedade do conhecimento, o recurso humano - que é o verdadeiro detentor do conhecimento - é o recurso mais importante.

- Igualdade: estruturas horizontais sem definições de hierarquia e onde todos são considerados colaboradores.

- Gerenciamento: as organizações são administradas por pessoas que tomam decisões que atendam a missão da organização sendo que estes administradores funcionam muito mais como condutores do que comandantes. 
- Autonomia

- Descentralização

- Condição Desestabilizadora: a nova sociedade tem como uma das suas principais características o caráter de mudança e inovação e toda organização tem de ter uma boa capacidade de gerenciar estas mudanças desestabilizadoras (muitas vezes geradas por elas mesmas ), além de estar voltada para uma permanente criação inovadora

KUMAR (1997) de uma maneira mais específica e mais ligada a manufatura recorre às chamadas teorias denominadas por ele de pós-fordistas e que reúnem as grandes mudanças em um único divisor de águas - a especialização flexível -. A especialização flexível vem de encontro às novas necessidades de bens/serviços produzidos de acordo com o gosto dos clientes ao contrário da produção em massa e padronizada que vinha sendo feita até então. $\mathrm{O}$ mercado de massa se fragmenta diversificando os grupos de clientes e as empresas lançam mão de modificações tecnológicas à nível de produção - com o surgimento das máquinas baseadas em controle numérico para flexibilizar sua produção, Máquinasferramentas numéricamente controladas permitem a produção econômica de pequenos lotes de bens - tanto de capital como de consumo - , voltados para setores especializados do mercado. As novas máquinas tornam possíveis mudanças rápidas de produção em resposta a novas oportunidades e necessidades" (KUMAR, 1997, p. 55-56).

Este novo tipo de produção exige mais flexibilidade que tamanho (escala), o que favorece o surgimento de empresas de pequeno porte e mais flexibilidade e perícia dos operadores das máquinas o que lhes confere maior importância no processo produtivo. Modificações produtivas são colocadas em KUMAR (1997) de forma a que se tenha uma organização inserida em um contexto de produção de "produtos sob medida, fragmentação da força de trabalho, certo grau de desintegração das empresas e descentralização da produção (KUMAR, 1997, p. 76). 


\section{c) Mão de Obra}

Outro aspecto a ser salientado é o tratamento que DRUCKER (1994) dá ao fator mão de obra e ao seu papel na sociedade pós capitalista ainda em formação. A afirmação básica é que esta sociedade, além de uma sociedade de organizações como foi exposto acima, também é uma sociedade de empregados. Em primeiro lugar se observa que hoje existe uma incidência crescente de trabalhadores não remunerados da forma tradicional, alguns recebem uma autoremuneração (profissionais liberais) ou honorários (consultores), ou ainda outros não recebem qualquer espécie de remuneração, dedicando cada vez maior parte de seu tempo como voluntários em centenas de organizações assistenciais existentes, por outro lado também se observa que os trabalhadores que ainda recebem da forma tradicional, o fazem sempre através das organizações impessoais. Estas entidades se constituem então no único acesso disponível para o indivíduo ter sucesso, interagir com a sociedade e dar sua contribuição para a mesma. Até a posição da família, como instituição que ocupava esta função é contestada por (DRUCKER, 1994) ao ser observado especialmente nos países desenvolvidos, um expressivo aumento de unidades familiares com somente um responsável.

Tendo em vista esta perspectiva, e levando em consideração a dimensão dada pela sociedade do conhecimento, temos em destaque três tipos de trabalhador. $\mathrm{O}$ trabalhador em serviços que executará serviços subalternos e domésticos. Este tipo de trabalhador, é o sucessor do antigo assalariado e um grande desafio social por ser a camada mais indefesa e menos aparelhada da nova ordem. Tem-se o trabalhador do conhecimento que ocupa uma posição nova: ele depende de e age dentro de uma organização, mas contudo, pelo fato de deter consigo o recurso/fator produtivo mais importante, tem uma independência e mobilidade jamais sonhadas pelo antigo trabalhador das indústrias da revolução industrial, que dependia da máquina para trabalhar. Por fim, temos o trabalhador qualificado em serviços que seria uma espécie intermediária entre os dois anteriores.

Um aspecto interessante da sociedade dos trabalhadores do conhecimento a se salientar na obra de DRUCKER (1994) é que além de estes trabalhadores deterem individualmente o principal meio de produção - o conhecimento - , indiretamente porém coletivamente e através do advento dos fundos de pensão, ele acaba detendo o capital, subvertendo completamente a antiga ordem da sociedade capitalista onde o trabalho servia o 
capital. Com o aumento da expectativa de vida, aumenta necessidade de mais recursos para sustentar pessoas após sua vida profissional. Surgem então os fundos de pensão que capitalizam estes recursos em uma magnitude enorme e começam a buscar remuneração do capital por eles acumulado assumindo o controle das empresas Assim, os fundos tornam-se em uma das maiores fontes de capital existentes no mundo desenvolvido. Tem-se um capitalismo com os fundos de pensão onde paradoxalmente os trabalhadores, mesmo que indiretamente acabam detendo os meios de produção. Neste capitalismo sem capitalistas os que comandam a empresa não são mais os donos, mas sim gerentes /empregados que devem satisfação aos acionistas - os fundos de pensão - que se tornam os proprietários legais das empresas. Em última análise os próprios pensionistas se constituem nos verdadeiros donos .

De todo modo, é importante reter da contribuição de DRUCKER (1994) que fazer e movimentar coisas tem adquirido uma posição cuja importância para o processo produtivo é decrescente, importará muito mais o aumento da produtividade. Exemplo que atesta este fato é a exportação de mão de obra que os países mais desenvolvidos têm feito para o terceiro mundo, através da transferência de plantas produtivas e intensivas em mão de obra. O que importa daqui para frente é deter o conhecimento para projetar e comercializar produtos e serviços investindo na formação de trabalhadores do conhecimento.

Neste ponto KUMAR (1997) exerce suas observações críticas com um pouco mais de ênfase. Com relação ao conhecimento e sua relação com as teorias a respeito da sociedade da informação, o autor inicialmente define a influencia do conhecimento no trabalho e destaca duas manifestações desta influencia. A primeira seria ao nível de conhecimentos relativos a trabalhos já existentes incrementando e desenvolvendo os mesmos por meio de avanços tecnológicos, nesta manifestação, trabalhador vai aumentando a sua qualificação. A outra manifestação se dá na direção da criação de novas formas de trabalho no setor do conhecimento criando o trabalhador do conhecimento.

Ocorre então o "surgimento de uma nova classe de serviço de trabalhadores do ramo do conhecimento, homens e mulheres cujo trabalho por altos níveis de perícia técnica e conhecimento teórico que correspondentemente exigem longos períodos de educação e treinamento", (KUMAR, 1997, p. 37). Desta vez em consonância com as posições de DRUCKER, KUMAR dá um destaque importante ao ensino e pesquisa superiores criadores 
de conhecimento : "as fábricas de conhecimentos, as universidades e institutos de pesquisa, são agora usinas de força da sociedade moderna, substituindo a fábrica produtora de bens da era industrial.(KUMAR, 1997, p. 37)

Contudo a partir deste ponto surgem diferenças entre os dois autores, enquanto que para DRUCKER os trabalhadores do conhecimento prenunciam e consolidam a nova era do conhecimento da sua sociedade pós capitalista, KUMAR mais cético quanto as reais evoluções desta era, observa que na verdade o que se vê é um aumento expressivo de trabalhadores em serviços não sofisticados colocando em dúvida a natureza revolucionária da sociedade da informação e do conhecimento. De modo geral, as capacitações podem ter assumido um novo patamar, mais elevado e sofisticado que o dos trabalhadores das industrias mas o caráter mecânico e alienante do trabalho se reproduz neste novo patamar de forma parecida com o dos antigos proletários pois, "na medida em que o taylorismo continua como princípio dominante, a tecnologia da informação possui maior poder de proletarizar do que de profissionalizar" (KUMAR, 1997, p. 37). O autor observa um "crescimento do número de empregados de nível baixo, concentrados no setor de transferência de informação e não em cargos que requeriam maior qualificação e ligados a produção da informação (KUMAR, 1997, p. 39).

\section{d) Responsabilidade}

Para DRUCKER (1993), embasando toda esta estrutura, surge a necessidade de uma organização baseada em responsabilidade e não mais em poder, até porque os trabalhadores serão especialistas que não poderão mais ser submetidos a autoridade e comando tradicionais mais sim liderados com responsabilidade para que também se tornem responsáveis. Chega-se então a uma situação na qual cada um assume suas responsabilidades, não existindo subordinados mas sim associados que controlam seu trabalho e tomam decisões. A missão de uma gerência nesta nova situação é justamente delegar com responsabilidade objetivando tornar cada trabalhador um contribuinte produtivo para a organização dando o melhor de si para isto. A responsabilidade deve ser o foco e o principio formador da sociedade e das organizações que a constituem. A responsabilidade de uma organização se manifesta por exemplo no entendimento por parte desta de que os seus 
direitos terminam quando começa o direito social e também na definição clara de uma missão e da importância do entendimento correto e da defesa desta missão para o sucesso da organização.

Em suma, tem-se o tema conhecimento inserido no capitalismo, organizando toda a atividade econômica em torno da informação. Em outras palavras, tudo se baseia na produção e distribuição do conhecimento e da informação e não mais na produção e distribuição de coisas. DRUCKER (1994) dá um exemplo da indústria farmacêutica que produz conhecimento "encapsulado" sob a forma de remédios desenvolvidos com base no conhecimento e na tecnologia. A economia então não se baseia mais nos recursos tradicionais como mão de obra e capital, agora os produtores de riqueza e recursos mais importantes serão a informação e o conhecimento.

Finalmente seria importante salientar que esta obra de DRUCKER (1994) possui o que se poderia chamar de uma lente de nível "macro", isto é, trata-se de um estudo que aborda questões/caracterizações amplas relacionadas com um período da sociedade capitalista ocidental (ou ocidentalizada se incluirmos os países asiáticos), tal como ela se consolidou após a II Grande Guerra (início da década de 50). Este período apresenta, segundo o autor, um caráter acentuado de mudança e uma transição tão profunda que fará emergir na virada do próximo século - porque esta fase ainda não terminou - uma sociedade cujos valores econômicos, políticos e produtivos serão completamente diversos dos valores que permeiam a sociedade capitalista atual.

Uma das identidades mais evidentes na obra de DRUCKER (1994) seria a colocação do fator conhecimento (conhecimento este que surge como atributo de pessoas os trabalhadores do conhecimento -) como uma vantagem competitiva que deve ser buscada pelas empresas.

\subsubsection{Competitividade}

A globalização econômica e a nova sociedade passam a gerar uma revolução empresarial baseada na tecnologia avançada, na organização flexível e enxuta e na 
competição intensa com perspectiva mundial, sendo que todos os aspectos relacionados com a gestão e o planejamento das empresas começam a sofrer mudanças radicais, mudanças estas que impõem uma série de desafios aos administradores da empresa do final do século. A administração estratégica definida como um "processo contínuo e interativo que visa manter uma organização como um conjunto apropriadamente integrado ao seu ambiente“ (CERTO \& PETER, 1993, p. 6), mais do que nunca passa a ser uma área crítica dentro do processo administrativo com grande importância na condução de organizações bem sucedidas e na superação, por parte destas organizações dos novos desafios impostos pela globalização.

Um dos maiores desafios dos anos 80 e 90 diz respeito justamente a questão da concorrência no contexto global, um contexto marcado pela evolução tecnológica acelerada, pela maior exigência dos clientes e pela concorrência acirrada e globalizada. Neste contexto, o fator competitividade passa a ser encarado com maior ênfase. A competitividade de uma empresa ou de uma nação, segundo o ESTUDO da Competitividade da Indústria Brasileira (COUTINHO E FERRAZ -1994), passa a não se resumir apenas em uma questão de preços, custos e taxas de cambio. A competitividade é aqui definida dentro uma concepção dinâmica como a "capacidade da empresa em formular e implementar estratégias concorrenciais que lhe permitam conservar de forma duradoura, uma posição sustentável no mercado“ (COUTINHO \& FERRAZ, 1994, p. 18), e não mais apenas uma função da participação de mercado ou da eficiência técnica baseada em indicadores de produtividade. Esta abordagem dinâmica da competitividade elaborada em COUTINHO \& FERRAZ (1994) indica que o desempenho é condicionado pelas capacitações acumuladas, associado à estratégia competitiva aplicada pelas empresas, de acordo com seus julgamento a cerca da natureza da concorrência da qual fazem parte. Este processo geraria as chamadas vantagens competitivas (que serão analisadas mais adiante) superioridades operacionais em termos de preço, qualidade, distribuição, atendimento, etc., que destacam uma empresa das outras. O desempenho empresarial é também influenciado por fatores exógenos à empresa tais como a ordem macroeconômica, a infra-estrutura existente e o sistema político, sendo que além de criar vantagens competitivas a empresa deve sempre estar apta a reconfigurar seus atributos em respostas as inevitáveis mudanças ambientais de um sistema globalizado.

Temos então três fatores condicionantes da competitividade: 
- Os fatores internos a empresa: aqueles sobre os quais a empresa tem domínio direto, expressos pelos seus recursos acumulados e vantagens competitivas tais como: tecnologia utilizada, preparação e capacitação de pessoal conhecimento e flexibilidade diante do mercado, pós-vendas, relacionamento com clientes e fornecedores.

- Os fatores relacionados com a estrutura específica do mercado em termos de renda, localização, custos, escala, tecnologia específica, funcionamento da concorrência

- Fatores relacionados ao sistema tais como economia, política, fatores sociais e internacionais.

Uma condicionante interna decisiva de competitividade, segundo o trabalho de COUTINHO \& FERRAZ (1994), é o caráter de inovação que deve estar presente na estratégia da empresa que se pretende competitiva. A estratégia competitiva voltada para a inovação busca capturar novos mercados através da introdução/prática de novos produtos/processos e aplicar práticas que possibilitem maior eficiência e superioridade operacional diante dos concorrentes. A nível produtivo ou operacional, algumas inovações se tornaram condições para o atendimento de uma eficiência superior e consequentemente da competitividade. Estas inovações tem se dado nos terrenos da produção automatizada com equipamentos eletrônicos e das novas técnicas organizacionais tais como, JT, células de produção, filosofia e gestão da qualidade, controle estatístico de processos, normas ISO 9000. Outros aspectos são: investimento constante em tecnologia, melhoria contínua de processos através de investimento em aprendizado, capacitação de recursos humanos e caráter cooperativo das relações entre empresa e trabalhadores. Uma premissa básica é a de que a eficácia de gestão abrange e garante o esquema competitivo

Todas as considerações acima remetem para a necessidade de se avaliar a competitividade sob a luz da capacidade de uma empresa "gerar e implementar estratégias competitivas de sucesso através da identificação de fatores internos, setoriais e sistêmicos", (COUTINHO \& FERRAZ, 1994, p. 19) acima relacionados e que compõem a abordagem dinâmica da competitividade.

Em BACIC (1994), o conceito de competitividade, associado ao de estratégia empresarial é discutido dentro do contexto de economia globalizada que exige das empresas uma gestão baseada na obtenção de vantagens competitivas através da "inovação de 
produtos e processos, produção flexível, desenvolvimento de articulações com empresas, qualidade e concorrência baseada no tempo" (BACIC, 1994, p. 295). O ambiente concorrencial - principal fator que move o sistema capitalista de produção - induz a prática por parte das organizações de decisões estratégicas voltadas para a construção da competitividade através da criação de vantagens competitivas sustentáveis e num horizonte de longo prazo. Estas vantagens se traduzem no aprimoramento de fatores operacionais que contribuem para a competitividade, tais como avanço tecnológico, capacitação de recursos humanos, endividamento, lead-time e flexibilidade para reagir rapidamente às mudanças de mercado. Este autor compartilha da visão sistêmica de competitividade, colocada em COUTINHO \& FERRAZ (1994), onde a competitividade resulta da convergência de fatores internos, estruturais (específicos ao setor de atuação) e sistêmicos (macroeconomia). Os dois últimos fatores estariam fora da influência de uma empresa porém será a capacidade desta empresa de fazer frente a estes fatores, atuando na criação de vantagens competitivas sustentáveis, que determinará também a sua competitividade. Além desta dimensão exógena da competitividade, outras formas de criação de vantagens competitivas - incrementos de competitividade - são relacionadas, tais como:

- Geração de valor para os clientes

- Negociações e relações baseados no conceito de ganha-ganha

- Relacionamento avançado com fornecedores

- Gestão da qualidade

- Redes de empresas

Em outro trabalho, COUTINHO (1992) coloca a competitividade como uma das grandes tendências que vem surgindo no cenário mundial dos anos 90. São definidas novas bases de competitividade que passa a incluir a inovação tecnológica como fator básico. A competitividade passa a ser encarada dentro de uma visão sistêmica - o sucesso e a liderança não dependem apenas de fatores internos às empresas mas também do ambiente que as rodeia, (no que é chamado por COUTINHO de externalidades benignas) e da capacidade de interação das empresas com outras organizações, especialmente centros de pesquisa geradores de inovações tecnológicas. Outro fator é baseado no reconhecimento de que a competitividade não depende mais apenas de condições naturais presentes, tais como recursos em abundância mas da construção de vantagens competitivas através de estratégias 
voltadas para a inovação. Inovar aqui não significa apenas fazer algo inusitado mas também operar e gerenciar eficientemente uma combinação apropriada de processos de trabalho, estoques, controle de qualidade, preparo da força de trabalho, engenharia, etc. assim tem-se uma combinação da inovação pura (novos produtos e processos) com a inovação produtiva (produzir com eficiência) sendo que para o autor esta última chega a ser mais importante em termos competitivos do que a primeira. Uma palavra chave para a inovação produtiva será a capacidade de interação da empresa não só entre seus setores internos mas com outras empresas. Também é vital o preparo da mão de obra .

Resumindo, "a competitividade não advém simplesmente da dotação de fatores e de seus preços relativos.........., mas resulta de estratégias empresariais deliberadas de investimento, baseadas na capacitação tecnológica endógena e sistêmica para produzir com eficiência máxima e para introduzir novos processos e produtos........." (COUTINHO, 1992, p. 80).

\subsubsection{Dinamismo}

Um conceito administrativo importante a ser explorado é o conceito de Dinamismo, introduzido por GOLDMAN; NAGEL; PREISS (1995), juntamente com o conceito de redes de cooperação de Empresas Virtuais, já discutidos em item anterior e em maior detalhe.

A partir dos anos 80, uma nova forma de concorrência denominada concorrência dinâmica que vem substituir a concorrência baseada na produção em massa, surge nas sociedades mais desenvolvidas e em determinados mercados considerados de vanguarda como produto dos avanços tecnológicos nas áreas de informática e telecomunicações. Maior variedade de produtos individualizados, porém em grande escala, menor ciclo de vida do produto e processamento de pedidos em lotes predefinidos são alguns paradigmas deste novo sistema onde as "empresas coordenam capacidades distribuídas geográfica e institucionalmente em uma única Empresa Virtual“ (GOLDMAN; NAGEL; PREISS 1995, prólogo). 
Os competidores dinâmicos são avaliados de acordo com a velocidade com que são capazes de identificar necessidades do cliente, encontrar oportunidades e convertê-las em produtos e serviços.

As empresas participantes deste sistema passam a ter vantagens competitivas consideráveis. Outra característica desta forma de concorrência é o caráter estratégico que o projeto/desenvolvimento de novos produtos individualizados ao máximo passa a ter para as empresas, substituindo o processo de fabricação em si. Surge a necessidade de se diminuir cada vez mais o tempo de desenvolvimento do produto e as redes de cooperação denominadas pelos autores de Empresas Virtuais, trazem a possibilidade de diminuição deste tempo de desenvolvimento, além da diminuição dos custos e riscos do negócio.

A mudança e a incerteza constituem-se em realidades do mercado com as quais as empresas tem que se haver. Aumenta a variedade de produtos e tem-se um ambiente de negócios onde as empresas competem globalmente com produtos/serviços voltados para nichos de mercado, individualizados, com tempo de vida curto, portadores de grande quantidade de informações e comercializados em um relacionamento contínuo com o cliente.

A concepção de Dinamismo segundo GOLDMAN; NAGEL; PREISS (1995) é uma resposta abrangente para a obtenção de lucros em mercados globais, em constante mudança e fragmentados, com produtos/serviços intensivos em qualidade e desempenho e de acordo com o gosto do cliente. O desafio para as empresas neste ambiente consiste em obter lucros em um ambiente turbulento e de competição intensa.

A resultante disto será um ambiente composto por empresas cujo processo que apoia a criação, produção e distribuição de bens e serviços está centralizado na percepção do valor dos produtos pelo cliente. A valorização da satisfação do cliente e da adição de valor ao mesmo, produzem uma quebra do paradigma da produção em massa. Agora importa saber o máximo possível sobre os clientes e como se relacionar com eles de maneira intensa e rotineira. Trabalha-se em torno da individualidade e especialmente em mercados de maior valor agregado e tem-se estratégias de negócio baseadas na valorização do cliente e produtos conforme especificações de clientes individuais. Outras resultantes desta nova concorrência são: 
- Empresa voltada para oportunidade do cliente

- Modos de operação e organização, em constante modificação

- Menor expectativa de vida das decisões

- Exploração de oportunidades com bens baseados em conhecimento e configurados para o cliente

- Produtos com variedade de modalidades, tempo de vida curto

- Cultivo de relacionamentos de longo prazo com o cliente para sustentar as famílias de produtos

- Desenvolvimento de produtos e serviços em cooperação/alianças com outras empresas, mesmo que sejam concorrentes diretos.

De acordo com a obra de GOLDMAN; NAGEL; PREISS (1995), as forças que estão alterando o mercado e as empresas na direção da competição dinâmica seriam:

\section{a) Fragmentação do mercado:}

Mercados de todo tipo estão se fragmentando em ritmo acelerado. Ocorre a criação de produtos cujo preço consiste em uma função do grau em que os clientes acreditam que eles possam tirar proveito, ou ainda que possam ser valorizados por esta compra. Disto decorrem três estratégias:

- Segmentação de grupos de clientes, com preços diferentes para os mesmos bens e dependendo da circunstância do negócio. Ex.: passagens de avião com o preço de acordo com a idade, época de reserva, etc.

• "Tenização" dos produtos: transformação de artigos comuns e de preço baixo em produtos especiais com preços mais altos e apoio de publicidade agressiva e audaciosa. (exemplo: tênis para diversas modalidades esportivas). Após este movimento, vem a imitação que transforma o artigo em coisa comum novamente. Ou seja, existe o lançamento de um produto caro que se torna novamente barato. (exemplo: telefone celular). O sucesso sustentado depende de as empresas adicionarem, continuamente um novo valor, ou ainda criar um fluxo constante de novos valores 
- Segmentação de mercados de acordo com funções, explorando economias de escopo, usando a capacidade de generalização das tecnologia. (exemplo: vários tipos de micros com os mesmos tipos de processador).

\section{b) Produção Vinculada ao Pedido em Lotes Predeterminados}

A produção torna-se individualizada, porém com preços próximos aos da produção em massa, sendo que os produtos são configurados de acordo com o cliente. A venda passa a ser impulsionada pela produção e não mais pela desova de estoques. Ocorrem inovações nos equipamentos de produção que geram escalas e custos menores e mais funcionalidade. Acontece uma verdadeira democratização das oportunidades de produção com empresas de todos os portes introduzindo produtos individualizados em pouco volume e para determinados nichos de mercado. Tem-se também a redefinição do conceito de quantidade econômica de pedidos e surgem medidas de desempenho tais como a razão entre o tempo total de produção e o tempo de tolerância do cliente. (exemplo: montagem de micros em lotes cada vez menores).

\section{c) Disponibilidades de Informações para Tratar Massas de Clientes como}

\section{Indivíduos}

A concorrência dinâmica vai além dos conceitos japoneses de fabricação enxuta. Ela permite que o cliente determine como será o produto, juntamente com o fabricante. A escolha passa a ser responsabilidade do cliente cabendo ao fabricante ajudar o cliente a articular sua necessidades e exigências. Assim o Dinamismo também é saber o suficiente sobre os clientes para ser capaz de lhes mostrar que eles podem desejar alguma capacidade que agora não desejam, provando que se pode criar alguma vantagem da qual eles podem se beneficiar. Não basta realizar um refinamento dos processos produtivos (conceito ligado a produção em massa), mas estabelecer relacionamentos interativos entre cliente e fabricante. 


\section{d) Redução do Tempo de Vida do Produto}

O tempo de vida menor, passa a se dar com uma maior proliferação de modelos, num ritmo acelerado de introdução destes novos modelos.

A diminuição do ciclo de vida se constitui em um produto da integração de funções empresariais da criação de relacionamentos interativos com os clientes e fornecedores e da reflexão sobre os processos e operações envolvidos. Ex.: carros, computadores, etc.

\section{e) Convergência entre Produtos Físicos e Serviços}

Os produtos passam a se constituir em uma fusão onde tem-se produtos físicos cujo grande valor está nas informações/serviços aos quais o produto dá acesso. (exemplo: empresas de hardware trabalhando junto a empresas de informação). Os artigos físicos se transformam em artigos comuns com baixa margem de lucro. Como consequiência desta convergência surge uma concorrência baseada na valorização do conhecimento, iniciativa e criatividade das pessoas e o valor agregado se desloca da fabricação para as informações e serviços. Na comercialização de produtos/serviços, surge um relacionamento contínuo ao longo do tempo entre os fabricantes e consumidores. O que o cliente realmente compra são informações e serviços. A eficiência com que o projeto é integrado a produção e as formas pelas quais o projeto e a produção são combinados as atividades de Marketing e vendas são fatores de lucratividade. $\mathrm{O}$ que adiciona valor passa a ser as soluções dos problemas do cliente obtidas por ele após adquirir um determinado produto/serviço.

\section{f) Redes Globais de Produção}

Esta tendência converge com a questão da globalizada já discutida em item anterior. Nenhum mercado lucrativo é mais exclusivamente nacional e nenhum fabricante é somente 
nacional. Tem-se um integração mundial de recursos de projeto, produção, Marketing e distribuição, com a união de capacidades complementares .

\section{g) Concorrência e Cooperação Simultânea Dentro da Empresa}

Novos movimentos no cenário empresarial baseados em parcerias, cooperações, joint ventures, Empresas Virtuais, fundindo capacidades similares para a diminuição de custos, aumento de escala, desenvolvimento de novas tecnologia e novas capacidades. Na produção dinâmica o valor é uma combinação individualizada de informações e serviços oferecidas pelos produtos.

\section{h) Infra - Estruturas de Distribuição em Busca da Personalização em} Massa

A concorrência dinâmica baseia-se em produtos individualizados e relacionamentos interativos com os clientes (exemplo: Marketing direto, TV a cabo, serviços de compra em casa).

\section{I) Reorganização da Empresa}

Com a pressão competitiva dos anos 80, as empresas geram iniciativas para preservar sua lucratividade e deter perdas de mercado adotando novas técnicas operacionais tais como just-in-time, qualidade total, reengenharia, etc.) e com o seu Gerenciamento baseando-se na delegação de poderes, integração da empresa e operações simultâneas através de equipes de funções interrelacionadas com poder decisão. As operações com equipes proporcionam meios para se lidar com projetos especiais e resolver problemas obtendo-se assim um rápido desenvolvimento de produto, alavancagem de recursos internos e de conhecimento, metas audaciosas, estabelecendo-se uma estreita relação entre o desempenho da pessoas e o seu impacto sobre as metas da empresa. 
No âmbito do Gerenciamento de recursos humanos, tem-se uma distribuição de autoridade na tomada de decisões em direção ao pessoal operacional, redução de hierarquia, ambiente interno com disseminação de informações, investimento em educação e treinamento contínuos, vendas e prestação de serviços associados e responsabilidade de todos.

Diminui o custo das informações e aumenta o valor destas para a melhoria da produtividade. As empresas estão criando ambientes de intercâmbio de informações ininterruptos em nível interno, e também com fornecedores e colaboradores.

\section{j) Pressões para a Internalização dos Valores Sociais Predominantes}

Tornam-se mais freqüentes as preocupações ambientais com energia, esgotamento e reciclagem de recursos naturais, segurança no trabalho, qualidade de vida, desemprego, treinamento de mão de obra, desenvolvimento regional. Ocorre também a ação do governo refletindo temores quanto ao abuso do poder econômico e crença na necessidade de se moldar do lado de fora do comportamento empresarial.

Em suma, o dinamismo traduz a idéia de um ambiente que requer das empresas um posicionamento ativo e flexível, voltado ao contexto, com a adoção da mudança de maneira agressiva e orientada para o crescimento, compartilhando-se mercados lucrativos com produtos ricos em informações e serviços, configurados conforme as exigências de clientes individuais e com a busca de um antecipação das exigências dos clientes. Tem-se uma nova visão de produção onde os serviços e pacotes de informações também são produtos apesar de intangíveis e o projeto é parte integrante da produção bem como as compras, Gerenciamento de estoque, Marketing, finanças, contabilidade, vendas, questões jurídicas, serviços de pós venda e suporte ao cliente, relações entre cliente e fornecedor.

Da empresa dinâmica é exigida uma reação rápida às oportunidades inusitadas. Para isso, é necessário um desenvolvimento rápido de produtos a custo mais baixo e que forneçam alta percepção de valor para o cliente através da individualização.

A concorrência dinâmica é caracterizada por um ambiente de mudança rápida, contínua e imprevisível. Tempo de vida curto de produtos altamente diferenciados e 
produzidos por uma força de trabalho ativa, motivada e organizada em empresas com autoridade distribuída e com linhas de produção mais curtas, com a produção vinculada ao pedido ao invés de previsões de Marketing, redução no tempo de desenvolvimento. A produção é realizada através de máquinas de produção flexível, automatizadas e controladas por computador.

\section{l) Dimensões da concorrência}

Na obra de GOLDMAN; NAGEL; PREISS (1995), são colocadas quatro dimensões da concorrência dinâmica:

Valorização do Cliente: A empresa dinâmica valoriza seus clientes e os produtos são percebidos como soluções para seus problemas individuais pois os clientes pagam por soluções. O preço é dado com base no valor das soluções fornecidas. Busca-se relacionamentos estratégicos com os clientes, estáveis e de longo prazo, através da venda de soluções aos problemas individuais do cliente que gerem valor ao mesmo. A produção se dá em grande volume, em lotes predefinidos e vinculados ao produto em um sistema de processamento e banco de informações que trata cliente individualmente. $\mathrm{O}$ bem mais importante da empresa é o conjunto de competências do seu pessoal ou as capacitações tecnológicas e a lucratividade se torna uma função da qualificação e conhecimento de seus funcionários e das informações que eles possuem ou às quais eles têm acesso. As competências dão sustentação ao desenvolvimento de produtos soluções e o projeto torna-se o propulsor do processo global de produção e permitindo aperfeiçoamentos. A estratégia de desenvolvimento de produtos também se dá com base no valor percebido pelo cliente, sendo que diminui o tempo de vida dos produtos pois aumenta o ritmo das inovações.

Cooperação para Melhoria da Competitividade: A cooperação é uma das chaves trazidas pelo novo conceito de dinamismo para a vantagem competitiva opondo-se ao individualismo até então existente nas empresas. Com a redução do tempo de ciclo do produto, surge a necessidade de grande redução de custos, riscos e tempo de comercialização. Também os serviços e informações aplicados aos produtos físicos tornamse importantes para a obtenção de lucro. Para se concretizar isto, é necessário um ambiente 
cooperativo deixando de lado o controle e a rivalidade e partindo para a ética da confiança. A cooperação acelera a transferência de tecnologia e amplia os recursos disponíveis para a solução de problemas, aumentando a probabilidade de soluções inovadoras. As alianças reduzem custos e riscos e tempos de desenvolvimento, aumentando os recursos humanos e físicos disponíveis e a probabilidade de sucesso. Neste contexto, as Empresas Virtuais são uma das formas de cooperação dentro e fora da empresa e serão discutidas em outro tópico.

Organização Voltada para Mudanças e Incertezas: A possibilidade de se prosperar em meio a mudanças requer uma dose de flexibilidade que permita rápida reconfiguração de recursos humanos e físicos para se atender às diferentes oportunidades de negócio. Neste ambiente os funcionários agem por delegação para se ter rapidez nas decisões e se constituem em um pessoal motivado e aberto a novos conhecimentos. Os valores anteriores de comando e controle criam relacionamentos adversos entre Gerenciamento e trabalho. É necessário então abrir mão do controle através de uma estrutura inovadora e flexível que reflete sua agenda estratégica. A reação à uma urgência competitiva de uma nova oportunidade gerada no cliente se dá através da sintetização da experiência necessária e da integração do acesso às instalações importantes e ao conhecimento onde quer que estejam, ocasionando altas taxas de lançamentos de novos produtos, passando-se da otimização da função gerêncial para a otimização da exploração de oportunidades de clientes. O pessoal é treinado para agir em âmbito local mas pensando no global.

Alavancagem do Impacto das Pessoas e Informações. No seu Gerenciamento a empresa empreendedora realiza a distribuição de autoridade através do fornecimento dos recursos necessários, criação de um ambiente de responsabilidade mútua e introdução de recompensas à inovação. $\mathrm{O}$ fator de diferenciação na concorrência dinâmica são as pessoas, o que elas sabem e sua iniciativa. A empresa então deve proporcionar educação e treinamento contínuo da força de trabalho. Se as pessoas e informações são os fatores de diferenciação dos concorrentes dinâmicos, o que uma empresa vende é sua capacidade de transformar o conhecimento, qualificações e informações incorporados em seu pessoal em produtos - solução para clientes individuais. O que os clientes pagam é o acesso às pessoas capazes de sintetizar produtos lucrativos, que valorizem clientes a partir do conhecimento que possuem e das informações e tecnologia que a empresa coloca a disposição deles. A 
primeira tarefa de um concorrente dinâmico é criar um ambiente na empresa capaz de alavancar o impacto de pessoas e informações em seus resultados, o Gerenciamento deve então fornecer os recursos sob forma de tecnologia de produção, comunicação e informação necessários para que a empresa possa concorrer em ambiente comercial dinâmico e para que a força de trabalho pense como o proprietário da empresa, adquirindo responsabilidade pelos problemas que afetam os resultados da empresa. A autoridade e a resolução de problemas devem estar ao nível mais próximo possível de onde eles tenham ocorrido com os funcionários mais diretamente afetados pelo problema. Uma determinante decisiva de vantagem na concorrência dinâmica, é a capacidade de se criar relacionamentos duradouros e estratégicos com os clientes, cujas necessidades estão em mudança constante. Uma empresa faz isto através do fornecimento aos clientes de famílias de sucessivas gerações de produtos de alto valor agregado, assim é mantido o acervo de competencias existentes, bem como as que serão necessárias no futuro e as que poderão ser obtidas em outras empresas. $\mathrm{O}$ ato de coletar, avaliar, organizar e distribuir informações é um fator de capacitação decisivo no desenvolvimento e entrega de produtos dinâmicos. (Ex.: valor dos componentes eletrônicos no valor total dos carros). A empresa dinâmica deve criar e manter uma cultura empreendedora de responsabilidade recíproca visando o sucesso da empresa, nela as pessoas pensam sobre seu trabalho e tomam suas próprias decisões, trabalham em equipes mas são avaliadas de acordo com suas qualificações pessoais e de como o desempenho de suas equipes influem no resultado global.

Em suma, para tornar-se um concorrente dinâmico é necessário compreender cada cliente, os mercados, os concorrentes, os produtos, as competências e os recursos. O dinamismo marca o surgimento de uma nova ordem industrial na realidade comercial.

O que um concorrente dinâmico vende são qualificações, conhecimento, experiência e informações em relacionamentos prolongados. A capacidade de valorizar os clientes é a conseqüência do papel exercido pelas pessoas em um ambiente onde a mudança (mudança de clientes, mercados e oportunidades) é a principal variável. O conhecimento do pessoal (e aqui tem-se uma identidade com o pensamento de DRUCKER) é a maior riqueza e as pessoas são o ponto vital para o sucesso estratégico da empresa.

Em resumo e segundo os autores, tem-se o seguinte, : 
As organizações dinâmicas:

- concorrem com base em suas competências

- atenção voltada para as pessoas

- dão valor ao aprendizado

- avaliam qualificações do pessoal

- são dotadas de agilidade e capacidade de pensar

Como tirar proveito do dinamismo:

- Satisfação do cliente através da diminuição do tempo

- Ser o primeiro com preços de líder

- Investimento no funcionário para ter um funcionário dinâmico e dedicado ao cliente

- Parcerias dinâmicas e cooperativas com acesso ao mercado mundial e lucratividade

\subsection{Novas Tendências Estratégicas}

\subsubsection{Estratégia Competitiva e Vantagem Competitiva}

MICHAEL PORTER, professor da Universidade de Harvard - USA, surgiu na década de 80 como um dos principais expoentes no campo da Estratégia nos últimos anos.

Através das teorias expressas em seus dois livros, Competitive Strategy (Estratégia Competitiva - 1984), e Competitive Advantage (Vantagem Competitiva - 1985), PORTER introduziu um novo e criativo enfoque que, associado ao rigor lógico com o qual apresentava seus conceitos, acarretou inúmeras adesões às suas idéias. Estas idéias estão baseadas na análise da estratégia com ênfase na posição competitiva das empresas, tanto em um determinado segmento como em relação a seus concorrentes. Um segmento aqui é definido como qualquer ramo empresarial (indústria, comércio ou serviços) onde exista “..um grupo de 
empresas fabricantes de produtos (produtos e/ou serviços) que são substitutos bastante aproximados entre si” (PORTER, 1986, p. 24).

A concorrência passa a ser considerada como um fator de sucesso ou de fracasso das empresas e saber lidar com a concorrência tornou-se uma questão vital, especialmente depois que alguns mercados anteriormente em crescimento, têm se tornado estáveis e até recessivos e os consumidores com isto vão se tornando cada vez mais exigentes quanto a preço e qualidade dos produtos /serviços.

A estratégia competitiva seria a busca de uma posição competitiva lucrativa e sustentável em um determinado segmento, contra as forças que determinam a concorrência neste mesmo segmento. Na verdade em termos estratégicos, importa cada vez menos se uma empresa apresenta um bom desempenho, mas o quão bom este desempenho está em relação aos competidores, ou fazendo uma analogia, não importa se uma empresa está correndo rápido, mas se está correndo mais rápido que a concorrência.

Segundo PORTER (1986), a escolha de uma estratégia competitiva envolve dois aspectos:

- A atração de um segmento em termos de rentabilidade de longo prazo: pois segmentos diferentes oferecem oportunidades de rentabilidade diferentes.

- A posição competitiva (rentabilidade) relativa de uma empresa, dentro de um segmento: pois algumas empresas dentro de um mesmo segmento são mais rentáveis que outras.

Ou seja, o objetivo de uma empresa é procurar estar em um segmento atrativo (vale dizer, lucrativo), sem deixar de estabelecer também diferenciais competitivos vantajosos em relação aos demais participantes do segmento em questão, atingindo assim uma rentabilidade acima da média de seus concorrentes. Tanto a atração de um segmento quanto uma determinada posição competitiva, podem ser modeladas pelas empresas através da escolha de uma estratégia competitiva pois a estratégia competitiva não está somente sujeita ao ambiente como também procura ajustar este meio ambiente em favor da empresa que a utiliza. 
A concorrência em um segmento, na visão de PORTER, adquire um caráter mais amplo que o sentido tradicional, onde são considerados apenas as outras empresas concorrentes. Aqui, os "concorrentes" são representados em cinco forças chamadas "competitivas" a saber:

a rivalidade entre os atuais concorrentes

- ameaças à entrada de novos concorrentes

- ameaças relativas a substituição de produtos

- poder de negociação dos fornecedores

- poder de negociação dos clientes

Estas cinco forças competitivas estarão agindo no sentido de diminuir a taxa de retorno sobre o capital investido de um segmento específico (potencial de lucro final), procurando diminuir esta taxa aos níveis básicos de concorrência perfeita ou no mínimo às taxas de retorno equivalentes aos títulos do governo.

A missão de uma empresa dentro de um segmento e de acordo com os conceitos da estratégia competitiva, é se defender destas forças e/ou influenciá-las a seu favor pois os investidores não tolerarão retornos reduzidos e irão procurar melhores oportunidades e isso fará com que a empresa obtenha cada vez retornos mais baixos e acabe saindo do negócio.

A intensidade e conformação das forças competitivas vai determinar a estrutura de um segmento, cada segmento possuindo sua configuração e sua atração (lucros potenciais) próprias, sendo que esta mesma configuração vai se modificando à medida que o segmento evolui.

Temos então que a lucratitividade potencial de uma empresa é determinada pelas cinco forças que são por sua vez determinadas pela estrutura industrial e suas características técnicas e econômicas .Assim, quanto maior a pressão das forças dentro de uma estrutura industrial, menor a condição de as empresas que atuam nesta indústria produzirem retornos atrativos sobre seus investimentos pois maior será a pressão sobre preços, custos e investimentos. 
Dentro deste contexto, uma empresa terá que inicialmente saber analisar e escolher bem o seu segmento, procurando sempre lidar com as forças competitivas de maneira mais eficiente que seus concorrentes, mas ela poderá também além disto influenciar e modificar as cinco forças através de suas estratégias competitivas, mudando assim as regras da concorrência e em consequiência disto, a estrutura e a rentabilidade potencial do seu segmento.

A metodologia das cinco forças de PORTER (1986) procura capacitar as empresas a compreender seus ambientes e detectar fatores críticos para a concorrência. Na verdade esta metodologia destaca as questões mais relevantes para a rentabilidade de longo prazo.

Vale a pena observar que, ao lado deste esquema está uma visão que pressupõe um papel crucial (no longo prazo), da estrutura de um segmento na geração/apropriação do valor criado pela produção de produtos e serviços, bem como na oferta/procura de bens e seus efeitos para a rentabilidade deste segmento.

Além do enfoque voltado para a atração do segmento, o outro determinante para a rentabilidade das empresas é a sua posição relativa dentro do mesmo. Este posicionamento irá dizer se a rentabilidade está abaixo ou acima da média. O objetivo no longo prazo será sempre buscar uma rentabilidade acima da média e este desempenho superior será obtido através da criação e manutenção de alguma vantagem competitiva.

Segundo PORTER (1992), existem a princípio duas formas/fontes de vantagem competitiva: baixo custo ou diferenciação de produtos/serviços. Estas vantagens se originariam da habilidade com a qual as empresas enfrentam as cinco forças competitivas. Estas duas formas de vantagens, combinadas com a amplitude com a qual a empresa resolve atuar - escopo amplo ou estreito de atuação - vão produzir as estratégias genéricas a saber: liderança em custos, diferenciação e enfoque (enfoque no custo ou enfoque na diferenciação).

A diferenciação seria o atributo percebido pelo consumidor e que impede sua comparação com os competidores, ou ainda uma forma de estratégia onde “...uma empresa única em sua indústria....” (PORTER, 1992, p. 12). Pode ser um produto diferente ou uma 
qualidade diferenciada, o objetivo principal é diferenciar o produto criando um atributo que seja percebido pelos compradores como único, por exemplo, a Mercedes Benz para automóveis ou a Rolex para relógios.

A liderança em custos significa obter um diferencial que, através de processos, eficiência ou com equipamentos, suplante a concorrência atingindo um custo baixo em relação à mesma, por exemplo, a Texas Instruments no ramo eletrônico ou a BIC para canetas.

$\mathrm{O}$ enfoque significa atuar em um segmento específico, especializando-se e conseguindo desta forma atender melhor que os concorrentes. Pode ser uma focalização regional, focalização por tipo de cliente ou por segmento de atividade.

Cada estratégia genérica implica em procedimentos e posicionamentos diferentes, surgindo a necessidade de que a empresa, para atingir um desempenho acima da média de sua indústria, faça uma escolha clara pois do contrário não será gerada uma vantagem competitiva e assim seu desempenho será abaixo da média sendo que esta empresa estará então na posição denominada "meio termo" ( PORTER, 1992, p. 15).

Um outro conceito importante dentro da estratégia competitiva é o conceito de sustentabilidade, isto é, uma empresa que deseja obter um desempenho acima da média de sua indústria deve praticar uma estratégia competitiva genérica que seja sustentável perante os seus concorrentes e ao longo do tempo. Em outras palavras, a vantagem competitiva que uma empresa adquire deve proporcionar-lhe condições de resistir aos fatores que possam atuar no sentido de enfraquecê-la tais como a ação de outros concorrentes e a evolução da própria indústria. Para isso, é preciso que sejam erguidas barreiras que dificultem a imitação de uma estratégia e que estas barreiras sejam, sempre que possível, incrementadas via investimentos para a melhoria de posição. 


\subsubsection{Competências Essenciais}

O termo "competências essenciais" (core competences) foi introduzido por HAMEL \& PRAHALAD (1994) e se tornou um do mais difundidos e presentes conceitos estratégicos, uma nova concepção que hoje permeia toda literatura técnica na área estratégica tornando-se até mesmo um termo de uso básico dentro desta área. O ponto de partida para a análise destes autores é a colocação da questão da competitividade como tema crucial para se medir o sucesso das empresas, empresas estas inseridas no contexto dinâmico, volátil e globalizado estabelecido a partir dos anos 90 . Um contexto no qual o que se sabe hoje pode não ter serventia amanhã. Os autores se preocupam com as formas de manutenção do que eles mesmos chamam de "vitalidade competitiva" como condição de existência de qualquer negócio.

Tradicionais paradigmas estratégicos, definidos como fatores de sucesso, tais como curvas de aprendizado, economias de escala, participação de mercado, etc., começam a não ser suficientes para explicar certas ocorrências verificadas no mundo dos negócios, relacionadas ao surpreendente desempenho de pequenas firmas japonesas, por exemplo, suplantando firmas muito mais poderosas em termos de recursos, tradição e fatia de mercado. As razões da maior eficácia destas empresas na utilização de seus recursos não seriam encontradas, segundos estes pesquisadores, nos aspectos operacionais ou de custo e relacionados com uma dimensão de curto prazo, mas sim numa visão e ações voltadas para o horizonte de longo prazo, criando-se a chamada "visão de futuro" e encontrada nas camadas gerenciais das empresas em questão. Com esta visão, metas ambiciosas são definidas e atingidas com uma combinação de novas formas de vantagem competitiva criadas ao longo do tempo e de forma contínua.

O fator competitivo tempo, que dominou os cenários e a ação estratégica dos anos 80, deu lugar a competição com base na flexibilidade e na busca de novas vantagens competitivas. Foi observado em algumas empresas um comprometimento com determinadas áreas específicas de um negócio até mesmo antes que surgissem os mercados para os produtos ligados a estas áreas, demonstrando uma ação direcionada para a criação de habilidades ou competências voltadas para futuros mercados (numa postura coerente com a visão de futuro), sendo que o acerto em termos de previsão destes mercados se revela maior 
em certas empresas do que em outras. Além da situação de mercado atual, surge então a necessidade de uma preocupação com a criação de novos mercados e produtos através do desenvolvimento das competências específicas para isto (exemplo: competência em miniaturização - mercados de chips e PCs), desenvolvimento este nascido de um consistente comprometimento com a busca de novas formas de negócio e reformulação de setores.

O desenvolvimento de competências voltadas para futuros mercados e a transformação desta visão em realidade é colocada dentro de um contexto de revalorização da estratégia como um fator fundamental para o sucesso desta prática de transformação de mercados e construção de posições de liderança. Um conceito fundamental aqui é o da “criação de uma perspectiva para a empresa no futuro" (HAMEL \& PRAHALAD, 1994, p. 4) e de novas regras de competição. Isto se dará através da criação de condições e perspectivas para este futuro e para a empresa. Em outras palavras, a empresa se transforma definindo-se novas formas de negócio, criando novos recursos e novos padrões de satisfação dos clientes ou ainda a definição de novas regras ao invés de seguir as já existentes. Em suma, a busca de novos negócios deve ocupar o mesmo espaço que a preocupação com a eficiência operacional, a restruturação e a reengenharia, e as possibilidades de novas formas de faturamento o mesmo espaço que as reduções de custos. Os autores preconizam que uma parcela considerável dos esforços de melhoria de uma empresa deve estar voltado para a criação própria de novas vantagens competitivas e não apenas de reforçar as existentes e acompanhar a concorrência. A criação de novas vantagens passa então pelo desenvolvimento de competências específicas, eleitas pela empresa como as necessárias para o desenvolvimento das novas vantagens, este processo levando por sua vez à criação de novos produtos.

Ao se voltar apenas para a manutenção dos processos/mercados já existentes e do acompanhamento dos concorrentes, a empresa corre o risco de apostar todas as suas fichas em atividades cujo potencial de lucros é necessariamente declinante. Cumpre, portanto fazer esforços no sentido de se buscar o novo, a redefinição de processos, produtos e mercados através do desenvolvimento de competências/capacidades requeridas para isto. Segundo os autores, os gerentes das empresas vencedoras devem atuar com uma visão mais de “arquitetos, imaginando os negócios de amanhã do que engenheiros de manutenção 
conservando o presente" (HAMEL \& PRAHALAD, 1994, p. 2), buscando assim, além de acompanhar os concorrentes, superá-los e liderá-los.

É feita uma crítica à relevância excessiva dada aos processos de restruturação (enxugamento, dowsising, diminuição de custos) e reengenharia (reformulação profunda de processos de procedimentos) que vem sendo amplamente difundidos nos meios gerenciais em detrimento de uma verdadeira preocupação com a construção do novo. A relevância destes processos para a melhoria da eficácia operacional das empresas não é negada mas é considerada insuficiente para garantir um futuro competitivo e de sucesso para uma organização. A razão é que estes movimentos estariam demasiadamente atrelados as condições de produção atuais só que "não basta que uma empresa diminua seu tamanho e aumente sua eficiência e rapidez; por mais importantes que sejam estas tarefas, ela também precisa ser capaz de se reavaliar, regenerar suas estratégias centrais e reinventar seu setor, "Em suma, uma empresa também precisa ser capaz de ser diferente" (HAMEL \& PRAHALAD, 1995, p. 17). Na busca do novo, da liderança e da competitividade, a proposta é a empresa, além da restruturação (menor tamanho) e da reengenharia (maior eficiência), partir para a chamada regeneração de suas estratégias, ou ainda a reformulação ampla da visão da estratégia de negócios de uma empresa em busca da capacidade de explorar novas oportunidades antes dos seus concorrentes.

Esta busca implica na definição de novos clientes, canais, concorrência, produtos/mercados. Esta definição será obtida através de novas bases de vantagens competitivas que, por sua vez serão criadas através do desenvolvimento novas capacitações e habilidades - as competências essenciais (core competences). Mesmo sendo líder hoje nada garante que uma empresa o será amanhã a menos que ela esteja preparada para as inevitáveis mudanças que ocorrerão com seus mercados no médio/longo prazo. Do contrário esta empresa corre o risco de ser facilmente suplantada por empresas, não necessariamente mais poderosas mas que simplesmente surgem oferecendo soluções inusitadas e exploram oportunidades não ortodoxas (e que inclusive transformam o setor onde atuam) e que porão abaixo décadas de sucesso das empresas que não estiverem também voltadas para o novo.

É importante frisar que a questão das vantagens competitivas transcende o universo organizacional interno das empresas, vale dizer que, além e acima da transformação 
organizacional (dimensão interna), a empresa deve visar a transformação do próprio setor onde atua (dimensão externa), e só assim será obtida a liderança. Esta transformação do setor de atuação será por sua vez atingida através de uma reconfiguração geral da empresa direcionada para novos mercados pois certamente, após algum tempo, suas práticas acabarão por se tornar inadequadas frente às novas condições de mercado que serão estabelecidas. Diante disto, é preciso empreender uma constante reinvenção das estratégias básicas e das habilidades específicas que norteiam os passos de uma organização, um termo usado pelos autores neste sentido é a prática da "interceptação de novas tendências", (HAMEL \& PRAHALAD, 1995, p. 21). A regra para as empresas é movimentar-se mais rapidamente que a concorrência no sentido de se adaptar às mudanças ambientais detendo a consciência dos novos rumos que o setor deve tomar e da influencia que deve ser exercida por uma empresa na determinação destes rumos, só assim a empresa em questão deixará de ser um mero seguidor com lucratividades no máximo médias, para ser um líder de seu novo setor (ou setor reinventado), atingindo com isto lucratividades extraordinárias.

A questão da reformulação das estratégias tem um papel central na condução/liderança da mudança setorial, ao fazer isso uma empresa terá a garantia de chegar primeiro ao futuro é conservar sua liderança. A reformulação das estratégias implica em modificar de forma antecipada e evolutiva a habilitação de pessoal, novos produtos, novas práticas e procedimentos. A antecipação destas transformações é necessária para que não haja traumas, crises e prejuízos neste processo. Além da reconfiguração das estratégias e da condução das transformações setoriais, a empresa deve buscar também o melhor aproveitamento possível das oportunidades (eminentemente globais) que surgem ao longo do tempo, numa autêntica competição pelo futuro, onde o que mais se valoriza é o desenvolvimento de uma capacidade de previsão dos rumos dos mercados e, uma vez feita a previsão, atuar no sentido de se desenvolver as condições - capacidades e habilidades necessárias para se obter o domínio deste processo de transformação dos mercados antes que os rivais. Assim a "competição pela liderança na aquisição das competências essenciais (core competences) precede a competição pela liderança de produtos e concebe a empresa como um portfólio de competências" (HAMEL \& PRAHALAD, 1995, p. 27, 257).

Definindo-se então o que seriam para os autores em questão estas competências essenciais - fatores chave para o sucesso competitivo - tem-se que as mesmas são definidas 
como uma reunião de determinadas capacidades e/ou tecnologia em torno de algum aspecto ligado à atividade da empresa, por exemplo, a competência de uma empresa em realizar um ciclo rápido de produção ( tempo mínimo entre o pedido e a entrega do produto). Acessório a esta competência tem-se uma série de outras habilidades cuja integração bem sucedida permite a concretização desta competência (projeto dinâmico, produção flexível, sistemas de entrada de pedidos adequados, gestão de estoques e fornecedores). A competência essencial seria aquela que contribuirá definitivamente para o sucesso competitivo de uma organização no longo prazo. Neste ponto os autores definem um critério para definir se uma competência é essencial ou não.

Para ser definida como essencial, inicialmente a competência deve atuar consideravelmente sobre o valor percebido pelo cliente, isto é, são as competências que transferem ao cliente "um benefício fundamental" (HAMEL \& PRAHALAD, 1995, p. 235), uma valorização visível aos olhos do cliente, ou então um conjunto de habilidades que uma vez aplicado dê uma vantagem à empresa em termos de custos que a coloque em evidência com relação aos seus concorrentes. Em segundo lugar a competência para ser essencial deve produzir na empresa que a detém uma diferenciação perante a concorrência. De nada adianta uma empresa desenvolver uma competência que pode ser facilmente copiada por terceiros. Por fim a verdadeira competência essencial deve se constituir em um acesso para novos produtos e mercados, ou seja, deve poder ser aplicada na produção voltada para outros mercados.

Tem-se então uma nova competição que não se dá em torno de mercados, produtos mas sim em torno da obtenção das competências essenciais, fontes de vantagem competitiva e que, de acordo com a visão de futuro exercida pela empresa dentro de sua reformulação estratégica, serão as necessárias para se alcançar no futuro a liderança de mercados (que foram reconfigurados pela empresa) ou aproveitamento de novas oportunidades.

É oportuno destacar aqui a contribuição de SALK; EVANS; SHULMAM et al (1992) sobre o conceito de capacidades como um contraponto mas também uma complementação do conceito de competências essenciais. Segundo estes autores, HAMEL \& PRAHALAD definem as competências como a combinação de tecnologia individuais e habilidades produtivas (competência em miniaturização, ótica, engenharia, etc.), em outras 
palavras, as competências seriam a facilidade com que competidores bem sucedidos conseguem penetrar e dominar novos mercados.

Para SALK; EVANS; SHULMAM et al (1992), uma competência técnica específica por si só não explica o sucesso competitivo de uma empresa em um determinado mercado, sendo que o que irá destacar esta empresa será o seu foco nas capacidades, processos de negócio. Assim, em um mercado determinado, além da competência em engenharia, seria necessária uma capacidade em, por exemplo, organizar as atividades necessárias para o desenho, produção, venda e distribuição de um produto de modo inovador e mais eficiente em relação a concorrência. Portanto, enquanto o conceito de competência essencial destaca as habilidades tecnológicas e produtivas em alguns pontos da cadeia de valor, as capacidades estão em uma dimensão mais ampla englobando toda a cadeia, sendo mais visíveis ao consumidor do que as competências. Conclui-se que ambas as visões são complementares e necessárias para se compreender as novas exigências competitivas a nível estratégico para os próximos anos.

\subsection{Visão Econômica Sobre Cooperação e Redes De Empresas}

Uma nova realidade a nível econômico e novos padrões de competitividade vem sendo demonstrados através de alguns países do primeiro mundo evidenciando-se "um novo paradigma de produtividade industrial e de eficiência econômica “ (TAUILE, 1994, p. 85). Mas, segundo TAUILE (1994) a resposta para os diferentes padrões de performance entre a firma não está necessariamente na base microtecnológica ou na flexibilidade resultante, mas sim nas formas de "cooperação entre os diversos agentes econômicos em diversos níveis da organização social da produção" (TAUILE, 1994, p. 86). O ambiente cooperativo em oposição ao caráter tipicamente de confronto do capitalismo tradicional, possibilita performances superiores e passa a exigir uma reformulação da teoria da firma existente na atualidade. 
O fato é que uma nova realidade histórica se impõe, estabelecendo a necessidade de novas teorias para explica-la e analisá-la. Uma questão de microeconomia tradicional como a de fazer ou comprar pronto, diante desta nova realidade, passa a ser colocada de formas diversas mas sempre em consonância com o novo ambiente cooperativo. Duas delas segundo, TAUILE (1994) se referem a questão da terceirização e da ênfase das redes de fornecimento externo ou de subcontratação e na dimensão interna das firmas com uma nova realidade baseada em cooperação entre gerência e demais escalões na obtenção de objetivos comuns, cultura participativa constituindo-se uma nova firma cujos recursos estratégicos passam a ser as informações e seus recursos humanos. Tudo isto é reflexo das mudanças macro relacionadas com o aumento da competição obrigando as firmas a desenvolver uma “capacidade de resposta aos sinais de mercado através de adaptação e mudança (em geral colocando em evidência as inovações)", (TAUILE, 1994, p. 88). Mas de novo este mesmo autor relembra que o principal fator de geração de vantagens comparativas (e competitivas) não estaria necessariamente na base técnica mas nos fatores organizacionais dinâmicos e que possibilitam uma empresa reagir e mudar diante de condições hostis de mercado ou criando estas mesmas condições aos seus concorrentes. Depreende-se que este movimento cooperativo interno e externo tem haver com a questão da competitividade. Assim a cooperação e concorrência acabam se constituindo em dois lados da mesma moeda, convergindo e coexistindo "em níveis diferentes e mais elevados de articulação"(TAUILE, 1994, p. 88)

Com relação a dimensão interfirma, existe uma condição no capitalismo atual e já amplamente confirmada de que para obter sucesso um empreendimento, necessita-se de "capacidade de enfrentar quedas de mercado e de reagir prontamente, ou mesmo de antecipar esta necessidade", (TAUILE, 1994, p. 89) e dentro deste contexto, o papel da cooperação inter e intrafirma ocupa lugar de destaque e é fato decisivo para a existência de eficiência econômica. Já se observou que estruturas cooperativas, como por exemplo a estrutura de subcontratação (terceirização), entre uma empresa grande (subcontratante) e outras menores (subcontratadas) proporciona um conjunto capaz de resistir e se adaptar às pressões de mercado. Uma das razões é de que entregando parte de suas atividades a empresas menores porém mais flexíveis uma grande empresa cria uma condição de flexibilidade para todo o sistema que se beneficia disto. Compromissos mútuos de longo prazo onde as pequenas empresas transferem sua flexibilidade e se beneficiam em troca de 
assistência financeira, tecnológica e organizacional dada pelas grandes geram uma estrutura cooperativa sólida, coesa, durável, confiável e eficiente o que faz com que apesar de se constituir em uma estrutura desverticalizada, sua estabilidade proporcionada pela cooperação intensa acaba por conter os custos de transação característicos desta mesma estrutura desverticalizada.

As consequências benéficas deste tipo de atuação, bem como sua adequação aos novos cenários competitivos se revela através da melhor qualidade dos produtos, menores tempos de entrega e menores investimentos em capital fixo. Com isto surge uma nova firma (conceito amplificado) que, segundo TAUILE (1994, p. 89), é “mais capaz de sobreviver e ser bem sucedida num ambiente instável" atuando com flexibilidade e rapidez e dentro de estratégias de longo prazo. Os sistemas cooperativos acabam por produzir estruturas produtivas mais fortes e ágeis, de um lado e empresas individuais mais dinâmicas (desde que a credibilidade e os compromissos mútuos sejam respeitados pelos seus integrantes).

Existe uma condição, apontada em TAUILE (1994) e que é fundamental para que o dinamismo seja produzido através da atuação de sistemas cooperativos. Esta condição está relacionada com a otimização da utilização produtiva, tanto em termos financeiros como de equipamento. Surge então uma flexibilidade dinâmica que possibilita que sejam produzidos produtos diversos em uma única linha de produção que tenha sido programada previamente.

Retornando à questão das transformações tecnológicas e empresariais dos anos 8090, já relatadas no item sobre a globalização, e recorrendo à contribuição de MAZZALI \& COSTA (1997), tem-se que um novo ambiente trazido por estas mudanças introduz condições mais dinâmicas e de difícil compreensão no âmbito do cálculo capitalista, fazendo com que surjam novas formas de competição e de obtenção de vantagens competitivas bem como formas de divisão de riscos. Na dimensão externa à empresa, tem-se novas formas de articulação/relacionamento das unidades econômicas produtivas, dentre as quais se destacam as ações de terceirização de atividades (enxugamento de estruturas e diminuição de custo fixo), a intensificação dentro de uma cadeia produtiva, de relacionamentos estáveis entre uma firma central (detentora de controle tecnológico ou de mercado) e seus clientes e fornecedores bem como alianças estratégicas entre empresas concorrentes visando complementação de competências e a conquista de novos mercados ou acesso à novas 
tecnologia. Passa a ser mais difícil definir os limites de separação entre os agentes econômicos e novas interrelações não vinculadas a fatores geográficos ou organizacionais surgem e sugerem um novo modelo de relações entre as empresas representado pela organização em rede.

As redes seriam então conformações organizacionais caracterizadas pela interdependência de diversas empresas, comportamento conjunto e interdependente entre clientes, fornecedores e parceiros e neste sentido são identificadas dois tipos de redes a saber: as redes verticais que estabelecem relações entre clientes e fornecedores e as horizontais que funcionam através da articulação de empresas afins. Ambas as redes não prescindem, da existência de uma empresa coordenadora que se constitui no núcleo da rede devido ao seu já mencionado fator tecnológico ou de mercado.

As redes verticais funcionam através da complementaridade de especialidade com conseqüente perda de autonomia em nome de fortalecimento do todo. À empresa coordenadora é facultado uma certa proeminência e um controle sobre a cadeia. $\mathrm{O}$ surgimento das redes verticais se dá por motivações ligadas à descentralização, fruto da reorganização de uma grande empresa e quase integração, entre os diversos membros de uma cadeia produtiva, mas a motivação central, segundo MAZZALI \& COSTA (1997), é a resposta que tem que ser dada pelo aparato produtivo diante de crescentes exigências de demanda. A verticalização vem então dar conta destas exigências através de integrações logísticas na produção e distribuição que visem aumentar a eficiência destes processos. As integrações se dão nos elos da cadeia produtiva se traduzindo na rede vertical.

Já a rede horizontal se constitui numa resposta às exigências tecnológicas e de competitividade ampliada trazidas pela globalização. Um ambiente organizacional onde concorrentes ou complementares fazem alianças e trocam/compartilham competências riscos e custos para fazer frente ao novo sistema global e explorar novas oportunidades onde quer que elas se apresentem.

MAZALLI \& COSTA (1997) destacam ainda que no âmbito da teoria econômica, a organização em rede surge associada ao problema da coordenação de atividades e recursos dentro da atividade econômica. Em oposição à teoria liberal, a coordenação espontânea do 
mercado e da decisões empresariais através do mecanismo de preços dá lugar a necessidade de um comportamento coletivo e intencional das organizações para o atendimento da competitividade e eficiência empresarial. A coordenação econômica consciente possui duas dimensões.

A dimensão da alocaçãa de recursos é amparada na teoria dos custos de transação que postula ser a questão da produção uma função das decisões sobre alocação de recursos. As transações seriam uma nova e mais sofisticada definição das trocas de bens que ocorrem entre os diversos agentes econômicos (empresas, trabalhadores e governo) e que envolveriam além da pura troca física, também um conjunto de comprometimentos acessórios (contratos, procedimentos, rotinas, etc.) a ela. Cumpre então, no contexto de maximização da eficiência na alocação de recursos, dar-se conta não só da minimização de custos produtivos mas também dos custos de transação associados às trocas de produtos pois estes também consomem recursos que poderiam ser melhor alocados. Custos elevados de transação significam imperfeições a nível de relacionamento com o mercado que de alguma forma restringem a eficiência mas podem ser eliminadas através de novas formas de gestão e coordenação empresarial. Um exemplo de custo de transação seria o relacionados à localização geográfica, especialização/limitação da mão de obra e equipamentos. A atividade empresarial será condicionada a uma dada localização geográfica ou uma determinada capacidade de equipamentos e/ou mão de obra. Para suplantar esta restrição geradora de custos indesejados e onerosos de transação, é que se fazem necessárias novas formas de coordenação/organização das atividades empresariais. Concluindo, dentro desta dimensão o valor da rede se revela na minimização destes custos.

A dimensão criaçãa de recursos emerge do conceito da produção como sendo a criação de recursos originada da aplicação do conhecimento e qualificações (competências). O conhecimento e as competências se constituem na base para a reunião, utilização e criação de recursos produtivos, gerando a especialização - "aprofundamento de conhecimento em determinadas áreas" (MAZALLI \& COSTA, 1997, p. 129). A especialização se constitui na base para o tratamento da questão da articulação entre empresas, pois dada a especialização generalizada de um lado e dados os custos de transação que devem ser minimizados de outro, a cooperação e articulação de empresas complementares ou parceiras sob a forma de rede surge como um caminho a ser seguido chegando a ser definido como a nova base da 
atividade econômica. A empresa deixa de ser uma ilha isolada para se tornar uma praticante da cooperação empresarial (e aqui são ressaltadas como mais significativas as cooperações tecnológicas e de subcontratação), e portanto tendo em vista ela não ser capaz de realizar todas as atividades como a mesma desenvoltura por ser especializada, vem a necessidade de serem estabelecidas relações com outras empresas. Associada a especialização, a inovação se constitui em outro fator determinante para a dinâmica empresarial, trazendo em si uma contradição: para se desenvolver a inovação devem ser utilizadas concentrações de conhecimentos e recursos - construção de capacidades - que de um lado proporcionam seu nascimento (da inovação) mas do outro restringem a condição de se criar novas inovações devido a mobilização da empresa em torno de uma única inovação específica. A forma de organização em rede surge novamente como uma forma de se contornar esta restrição, e assim a formação em rede tem seu principal valor a diminuição de custos (dimensão da alocação de recursos) e a potencialização do aprendizado e na viabilidade da inovação (dimensão da criação de recursos).

Uma referência importante colocada por COUTINHO (1992) e que faz parte de um conjunto de tendências inovadoras que retratam a dinâmica capitalista das últimas décadas, diz respeito às alianças estratégicas, mais especificamente as alianças denominadas pelo autor de tecnológicas. O aumento dos custos de pesquisa, tornado-os excessivos para apenas uma firma e dos riscos associados a estes projetos e a crescente importância de se impor e dominar padrões mundiais de mercado, induz a alianças muitas vezes formadas entre concorrentes em torno de objetivos comuns e que se formalizam através de joint ventures, acordos de cooperação, projetos conjuntos de pesquisa, etc. Se constata um aumento de competitividade de grupos que compartilham custos e riscos em alianças deste tipo. Esta alianças ocorrem inclusive entre empresas de continentes diversos e que assim o fazem devido ao fato de operarem em escala mundial ou ainda porque atuam em setores diferentes e buscam complementaridades tecnológicas.

COUTINHO (1992) chama a atenção para o fato de que a raiz do surgimento destas alianças é pragmática e voltada para a concorrência. “ .tem caráter pragmático, temporário e via de regra visa obter ofensivamente vantagens competitivas derivadas da liderança inovacional ou da imposição de soluções padrão, em benefício do grupo......" (COUTINHO, 1992, p. 86). 


\subsubsection{Redes Estratégicas e Gestão Estratégica de Custos}

Utilizando a contribuição de BACIC \& SOUZA (1996), tem-se que as novas dimensões assumidas pela competição empresarial - ênfase em qualidade, variedade de produtos com ciclo de vida curto, atendimento rápido ao cliente, flexibilidade, customização em massa, preços competitivos - passa a destacar os aspectos de relações entre as empresas e formas de organização em rede com atuação coordenada. À Gestão Estratégica de Custos (SCM), cabe a missão de participar da criação de vantagens competitivas de uma determinada rede, municiando a mesma com instrumentos eficazes de tomada de decisão. $\mathrm{O}$ SCM visa a utilização das informações de custos em termos da interação com agentes externos (ambiente macroeconômico) e interação com a concorrência, fornecedores, clientes, produtos substitutos e entrantes potenciais) e com isto alimentar os tomadores de decisão com informações adequadas para um ambiente globalizado em termos produtivos e caracterizado pelo avanço das tecnologia de produção e informação.

A forma de atuação em rede torna-se importante neste contexto pois consegue adicionar competitividade à um conjunto de empresas em termos de agilidade, identificação e exploração de oportunidades em ações conjuntas, distribuição de ganhos, diminuição de custos e riscos, mais qualidade em investimentos e melhor administração de fluxo de caixa. Ao reunir um conjunto de empresas complementares, cada uma delas concentrada em sua especialidade (core business) e externalizando suas outras competências não tão desenvolvidas, a rede de cooperação proporciona vantagens competitivas sobre a concorrência em termos de produtividade e competitividade conjuntas.

As redes são aqui definidas como um conjunto de organizações que atuam de maneira articulada/coordenada e cujos processos decisórios estariam primordialmente ligados à existência da rede. As redes não nascem necessariamente sob algum contrato, estes podem até dificultar as vantagens competitivas. Aqui importa mais a convergência de interesses, a interdependência dos agentes, o engajamento mútuo, durabilidade das relações, a fidelidade e a cooperação. 
Exemplos potenciais de redes colocados em BACIC \& SOUZA (1994), seriam as redes de fornecedores e empresa-mãe, acordos entre empresas de setores diferenciados (ou concorrentes) para desenvolvimento tecnológico, exploração de novos mercados e defesa contra entrantes substitutos. É valorizado o trabalho em conjunto, a divisão de responsabilidades e execução em um sistema de cooperação onde a questão da coordenação torna-se crucial e a sinergia estratégica um resultante importante. As redes valem-se da difusão eletrônica de informações e do ambiente internet para diminuir os custos de coordenação externa (e consequentemente a verticalização empresarial) e aumentar sua presença e sua relevância no mundo globalizado. Para vencer a concorrência acirrada, fatores como cooperação, conhecimento e aprendizagem são requisitos necessários na criação de vantagens competitivas. Atuar em rede e de forma coletiva significa aumento de competitividade através da maior agilidade e adaptação inerentes a este sistema e do menor custo através do compartilhamento de equipamentos, conhecimentos e riscos.

\subsection{Empresas Virtuais}

De acordo com o preconizado em GOLDMAN; NAGEL; PREISS (1995) a cooperação (interna e externa) visa levar os produtos com a maior velocidade e eficiência possíveis aos mercados consumidores e se manifesta de várias formas tais como parcerias, joint ventures, alianças estratégicas, novas corporações, sistemas de fornecedorsubcontratante, acordos cooperativos, licenças, terceirizações, etc. A prática da cooperação por sua vez acarreta novas ações organizacionais tais como as equipes de funções interrelacionadas, delegação de poder, reengenharia de processos de negócios, parcerias com empresas e dentre estas se destacam as Empresas Virtuais. Em termos de cooperação e especialmente no caso das Empresas Virtuais, abre-se a possibilidade para que a utilização dos recursos seja feita independentemente de sua localização e de quem os possui.

A cooperação é o valor fundamental dentro e fora da organização que pretende participar de uma Empresa Virtual A substituição da integração geográfica pela eletrônica faz com que as Empresas Virtuais passem a identificar suas próprias competências de padrão mundial e integrá-las com capacidades complementares, pois a concorrência dinâmica 
também definida em GOLDMAN; NAGEL; PREISS (1995) é global, sendo indiferente à situação geográfica das instalações e da localização das experiências.

Se constata que a prática da cooperação aumenta a capacidade competitiva das empresas e estimula a adoção da produção baseada na Empresa Virtual. Como prova disto, tem-se verificado um crescimento expressivo de pequenas redes virtuais de negócio (integração vertical e horizontal). Outro efeito da cooperação observado pelos autores e de fundamental importância para as Empresas Virtuais é o de que a mesma transmite confiança aos seus participantes, uma confiança sob a forma de reafirmação mútua das relações de dependência, o que se constitui, segundo os autores, em "um pré-requisito básico para que ocorra o almejado sucesso compartilhado" (GOLDMAN; NAGEL; PREISS, 1995, p. 97). Em suma, o acesso à Empresa Virtual, inicialmente através de esquemas cooperativos, é "uma arma fundamental no arsenal competitivo de uma empresa" (GOLDMAN; NAGEL; PREISS, 1995, p. 97).

A Empresa Virtual, de acordo com o modelo aqui adotado, é uma modalidade de aliança onde os recursos existentes e complementares em várias empresas predispostas a cooperação, permanecem onde estão mas são integrados para apoiar esforços em prol de um determinado produto durante um determinado espaço de tempo, com vistas a explorar uma determinada oportunidade de mercado.

Trata-se contudo, e segundo este modelo, de uma aliança oportunista de principais competências distribuídas entre várias entidades operacionais distintas dentro de uma empresa ou dentro de um grupo de empresas. Inicia-se com a identificação das principais competências necessárias a exploração de uma oportunidade, depois estas são sintetizadas (preferencialmente a baixo custo) sob forma de uma capacidade completa e unificada de produção, projetada para satisfazer as oportunidades geradas por um determinado mercado ou cliente.

Uma característica a ser destacada é de que a Empresa Virtual é invisível aos usuários e clientes e se mantém enquanto o mercado a sustentar ou enquanto existir lucro na oportunidade que surgiu e que justificou a sua formação. O relacionamento é interativo ocorrendo uma integração sem a multiplicação de sedes físicas e com a aceitação por todos 
os participantes da busca do sucesso conjunto com comprometimento e responsabilidade pelo sucesso do empreendimento.

Além do aspecto da complementaridade, a justificativa da existência de Empresas Virtuais se dá pela necessidade de obtenção de compartilhamento de recursos de infraestrutura, $\mathrm{P} \& \mathrm{D}$, custos e riscos. Com isto, ocorre uma valorização de oportunidades de desenvolvimento de produtos através da união de competências. Outras justificativas são listadas em GOLDMAN; NAGEL; PREISS (1995): redução de tempo de entrega, aumento da escala das operações e diminuição de custo sem perda de flexibilidade, compartilhamento do acesso das bases de fidelidade do cliente entre as empresas e uma migração acelerada da venda de produtos para a venda de soluções.

As vantagens de se operar por meio de Empresas Virtuais em detrimento do esquema tradicional podem ser resumidas: maior velocidade no lançamento de produtos, menores custos, melhoria da combinação dos recursos e exigências de mercado.

Outras facilidades geradas pelas Empresas Virtuais são:

- Reunião de recursos com rapidez

- Criação de recursos de maneira freqüente e simultânea

- Reflexão da complexidade de processos com fidelidade

- Aproveitamento de oportunidades com rapidez

- Apropriação da maior parte dos lucros da cadeia produtiva

- Compartilhamento de fidelidade de clientes, no conhecimento e nos contatos de mercado

- Compartilhamento na redução no tempo, riscos e custos e na melhoria de produtos

As premissas básicas pelas quais as Empresas Virtuais operam são:

- Centralização das principais competências em ambiente de concorrência dinâmica

- Delegação de poder, com equipes auto organizadas, autogerenciadas e de funções inter relacionadas. 
- Remuneração de acordo com o desempenho e qualificações, redução da hierarquia gerêncial, distribuição de autoridade e decisões na ponta.

Os autores procuram salientar que uma das idéias centrais das Empresas Virtuais é compartilhar recursos, instalações e principais competências para atingir objetivos de concorrência global com a mesma integração de competências, recursos e oportunidades a nível de mercado. Em suma, uma verdadeira "equipe de craques" (GOLDMAN; NAGEL; PREISS, 1995, p. 195) com compromisso de divisão de riscos e custos. Assim, A Empresa Virtual se constitui em uma ferramenta organizacional eficiente para a concorrência dinâmica situada em um ambiente caracterizado pela mudança, incerteza, rapidez e pelas oportunidades de mercado.

As características mais marcantes de uma Empresa Virtual são adaptabilidade, oportunismo, excelência, tecnologia, ausência de fronteiras, confiança, formação visando aproveitar uma oportunidade para depois ser desativada após a exploração desta oportunidade que a gerou..

Com relação aos mecanismos de funcionamento da Empresa Virtual, o que é novo é o grau de utilização dos recursos e a intensidade da cooperação, não havendo em princípio necessidade de formação de nenhum instrumento legal para o início e prosseguimento das atividades pois existirá uma relação de confiança que substituirá esta necessidade.

Além das razões organizacionais mais evidentes, GOLDMAN; NAGEL; PREISS (1995) detalham seis aspectos estratégicos, aplicáveis ao conceito de Empresa Virtual e relacionados com a concorrência dinâmica:

\section{a) Infra-estrutura, P\&D, Custos e Riscos Compartilhados}

Acesso a equipamentos para produção especializada, realizando atividades e projetos que uma empresa não poderia, ou não deveria fazer por conta própria. 


\section{b) União de Principais Competências Complementares}

Atendimento de clientes que em separado não seriam atendidos. Cada um participa oferecendo algo exclusivo visando o aproveitamento de uma oportunidade.

c) Redução do Conceito de Tempo por Meio do Uso de Bens Compartilhados

Capacidade de várias empresas operarem em paralelo desempenhando diversas tarefas simultaneamente, o que aumenta a velocidade de desenvolvimento e diminui o conceito de tempo. Espera-se apenas que as empresas que atuam em cooperação sob o modelo de Empresa Virtual, sejam compatíveis em termos de tecnologia, cultura corporativa e metodologia de negócios, com atividades que eliminam processos em série o máximo possível.

\section{d) Aumento das Instalações e do Tamanho Aparente}

A Empresa Virtual se constitui em uma forma de alavancar a capacidade de satisfazer e valorizar o cliente. A Empresa Virtual consegue assim mostrar segurança, mais capacidade e potencial financeiro. Com a globalização as empresas precisam oferecer um perfil mundial aos seus clientes e poder atendê-los em qualquer lugar do mundo.

e) Acesso a Mercados e Compartilhamento dos Mercados ou da Fidelidade ao Cliente

Como exemplo, tem-se as franquias. Através delas os empreendedores procuram ganhar acesso a um conjunto de expectativas de mercado. Vários exemplos são dados relativos a coexistência de marcas (Intel inside em micros de todas as marcas; produtos Sears ou Carrefour, fabricados por diversos fornecedores). 


\section{f) Venda de Soluções e não de Problemas}

A percepção de valor se dá conforme o cliente. O valor das soluções depende da importância que o cliente atribui a ela. Ocorre assim o estabelecimento de preços com base em valor que se transfere ao cliente (sendo que este valor é percebido pelo cliente). Se visa com isto fazer com que o cliente perceba o produto como uma solução.

A seguir será definido o conceito de Teia Virtual também desenvolvido por GOLDMAN; NAGEL; PREISS (1995). O sucesso das Empresas Virtuais depende da capacidade das empresas se reunirem com rapidez para aproveitar uma oportunidade trabalhando de maneira interativa e com confiança. A concepção de teia virtual é um mecanismo dinâmico a ser considerado neste processo.

A Teia Virtual é uma situação anterior à Empresa Virtual, definida como um conjunto (formal ou informal) flexível de parceiros pré-qualificados que concordam em formar um grupo de membros potenciais de Empresas Virtuais, prontos a atender clientes cuja necessidade exceda a capacidade individual de cada parceiro. Para cada cliente, determina-se uma combinação exclusiva de empresas sob a forma de um relacionamento virtual de acordo com as exigências distintas daquele cliente.

Aqui já ocorre um compartilhamento de metodologias e de principais competências com a construção da capacidade dos membros de constituírem alianças oportunistas e entrar em concorrências que não seriam vencidas por apenas um deles.

Para a Teia Virtual ser efetiva, é preciso contar com um mecanismo para identificar as competências em desenvolvimento nos membros permanentes ou temporários. Outro fator é a forma pela qual ocorre a identificação e qualificação de oportunidades para a constituição de uma Empresa Virtual. Existe a necessidade de uma capacidade de marketing centralizado ou distribuído, forma pela qual a teia se beneficia em termos financeiros das atividades geradas por ela. Na verdade, a teia é o facilitador para a formação de uma Empresa Virtual e um mecanismo de sua viabilização. Já se percebe grandes corporações funcionando como 
teias em grupos de organizações pré-qualificadas, com cultura organizacional compartilhada e uma ou mais áreas de excelência em termos de oportunidade.

Um aspecto importante dentro da concepção de Empresa Virtual desenvolvida em GOLDMAN; NAGEL; PREISS (1995), é aquela relacionada com as regras para a divisão de lucros ou benefícios gerados por ela e resumidos a seguir:

- Todos se beneficiam quando um deles melhora o desempenho

- Todos que contribuem com alguma atividade (mesmo sendo de apoio), estão na equipe e dividem o lucro

- A participação na receita é determinada pelo custo base de cada um mais a participação nos lucros divididos pelos participantes das Empresas Virtuais.

- O lucro é dividido com base em resultados obtidos por cada membro da equipe. Estes resultados são distribuídos para cada membro com base na equalização do valor das contribuições anteriormente efetuadas na exploração da oportunidade.

- Deve ser preenchido um contrato de trabalho interno com os detalhes relativos às proporcionalidade e aos papéis a serem preenchidos.

Na questão concernente ao desenvolvimento e seleção de oportunidades, tem-se os primeiros passos iniciados com a identificação de uma oportunidade e da seleção de uma equipe neutra de marketing e de qualificações. Em seguida, os membros verificam as exigências do cliente, combinam as competências da Empresa Virtual e avaliam as chances de sucesso e retorno frente aos objetivos esperados de retorno. Posteriormente faz-se necessário estabelecer de que maneira os lucros serão distribuídos.

A existência de um mercado global com uma demanda crescente por produtos personalizados, estimulam as Empresas Virtuais enquanto mecanismo dinâmico que enfoca as oportunidades que exigem premência de tempo. A Empresa Virtual é baseada na idéia de que a cooperação valoriza a capacidade competitiva de seus membros (mesmo sendo concorrentes), podendo ser resumida em dois movimentos básicos: reunião de participantes para atender a uma oportunidade e desintegração após o fim da oportunidade. 
As Empresas Virtuais podem ser consideradas as corporações do futuro, com possibilidades reais de enfrentar os obstáculos atuais decorrentes da globalização dos mercados e de sua concorrência acirrada. Graças a sua agilidade e flexibilidade (inerentes a esta modalidade de negócio) a Empresa Virtual consegue reagir com a rapidez necessária às mudanças deste tipo de mercado. Contudo, dado o caráter recente de sua existência, é importante observar que as Empresas Virtuais e suas vantagens e desvantagens ainda estão sendo definidas em um processo não totalmente concluído.

Com relação à alguns dos pontos críticos relativos às Empresas Virtuais recorre-se a contribuição de CHESBROUGH \& TEECE (1996). É necessário reconhecer que deve ser colocada a necessidade de se delimitar e condicionar atuação das Empresas Virtuais a algumas situações específicas, por exemplo as relacionadas com o processo de geração e operacionalização das inovações tecnológicas e que se constitui no fator chave para obtenção de vantagens competitivas. Não se deve então considerar o modelo de produção baseado em em Empresas Virtuais como uma aplicação universal em qualquer situação de negócio.

Com efeito, a condição de virtualidade existente nas Empresas Virtuais enquanto alternativa de sucesso empresarial e estratégico, possui suas limitações. Em contraposição à empresa centralizada e integrada, a Empresa Virtual possui em sua virtualidade um fator que produz um incentivo e uma facilidade para seus participantes no que tange a capacidade de assumir riscos. Por outro lado e em determinadas situações as Empresas Virtuais devido ao caráter independente de seus participantes bem como uma tendência natural de procurarem maximizar benefícios para si, tendem a ter uma dificuldade com relação a resolução e coordenação de conflitos e equalização de interesses por vezes divergentes. Neste quesito a empresa centralizada e integrada, pela sua própria natureza - comando e controle centralizados e localizados na mesma unidade empresarial -, se encontra em melhores condições para suplantar este obstáculo operacional.

A partir do exposto acima, e tendo em vista a definição da inovação como a chave para a competitividade, CHESBROUGH \& TEECE (1996) colocam a questão da inovação dividindo-a em duas formas, sendo que, de acordo com cada forma, tem-se a possibilidade de se trabalhar no modo integrado ou virtual. 
Tem-se a inovação autônoma, ou seja aquela que pode ser procurada independentemente de outras inovações, "they can pursued independently from other inovations", (CHESBROUGH \& TEECE, 1996, p. 67). Como exemplo, um componente turbo de um automóvel para aumentar a potência do motor sem que necessariamente toda a engenharia básica deste motor tenha de ser alterada.

Tem-se também a inovação sistêmica, cujos benefícios só podem ser obtidos mediante uma conjunção de outras inovações complementares e relacionadas, "their benefits can be realized only in conjuction with related complementary innovations", (CHESBROUGH \& TEECE, 1996, p. 67). Como exemplo tem-se o caso da Polaroid no mercado de fotografia instantânea, onde se fez necessário o desenvolvimento simultâneo de tecnologia em produção de filmes fotográficos e de câmaras.

A decisão sobre qual arranjo organizacional implementar está relacionada com a natureza das inovações. No primeiro caso, o das inovações autônomas, a atuação de Empresas Virtuais é considerada factível e com possibilidades de sucesso. Seu caráter descentralizado não se constitui empecilho para que sejam acionadas as atividades de desenvolvimento e comercialização das inovações, mas no segundo caso, inovações sistêmicas, a dependência mútua entre os membros de uma Empresa Virtual sem o controle mais próximo de uma empresa integrada torna este arranjo inadequado e com poucas possibilidades de sucesso.

A razão para esta diferenciação está na natureza das informações e conhecimento que alimentam o processo inovativo. Enquanto que o conhecimento ligado às inovações autônomas e mais facilmente padronizáveis e codificáveis, portanto de fácil transmissão entre as firmas, favorecendo modelo virtual, o conhecimento sistêmico, está mais enraizado dentro do "modus operandi" da empresa, sendo de difícil transmissão e então o modelo mais aconselhável será o centralizado ou integrado.

Em suma, existem algumas limitações com relação a atuação de Empresas Virtuais. Em determinadas situações, relacionadas com a natureza da inovação, a empresa tradicional - centralizada e verticalizada - é mais adequada. Os autores fazem alusão à possibilidade de 
um meio termo, com uma Empresa Virtual formada por uma grande empresa coordenando outras menores em um sistema cliente-fornecedores.

Uma outra reposta às restrições existentes a atuação de Empresas Virtuais pode ser encontrada na contribuição de HANDY (1995). Este autor coloca questão de como gerenciar e coordenar em um empreendimento virtual quando se tem uma situação com pessoas e empresas que não se vê. A resposta dada por ele mesmo seria pela instituição de esquemas de trabalho baseados na confiança. A aparente simplicidade desta formulação esconde a necessidade de um redirecionamento- "a turnaround in organizational thinking" (HANDY, 1995, p. 41), na forma tradicional de gerenciamento, baseada em controle para a obtenção da eficiência. Apesar de a ênfase de HANDY (1995) estar na Empresa Virtual baseada em trabalho descentralizado de indivíduos, desvinculado de um lugar físico comum, é possível se fazer analogia para um conjunto de empresas e utilizar os parâmetros fornecidos pelo autor no sobre o trabalho baseado na premissa da confiança, aliás a confiança segundo este autor ocupa a mesma relevância que a própria utilização de modernas tecnologias de comunicação para a viabilização da Empresa Virtual, "virtuality requires trust to make it work: Technology on its onw is not enough", (HANDY, 1995, p. 44).

HANDY (1995) estabelece sete parâmetros para se implantar com sucesso um trabalho virtual baseado em confiança.

a) A confiança não é cega: é preciso ter havido algum contato inicial e depois periódico entre as empresas para que se estabeleça uma relação de confiança.

b) A confiança necessita de limites: Algum controle sempre existirá, apenas estará circunscrito a verificação dos resultados.

c) A confiança necessita de aprendizado: Cada vez mais existe necessidade de adaptar-se às mudanças de mercado. Para isto é preciso estar predisposto a explorar novas oportunidades e tecnologia (inovações) e isto requer uma verdadeira cultura do aprendizado.

d) A confiança requer rigor: Caso algum participante se revele não merecedor da confiança nele depositada, este deve deixar o grupo. 
e) A confiança requer vínculos: $O$ fato de uma relação baseada na confiança pressupor um certa independência entre as partes não deve conduzir a uma situação de ruptura. Existe a necessidade de um convergência mínima de objetivos.

f) A confiança necessita de contato: Em que pese a não existência de vínculos geográficos ou de lugar, os participantes devem estar em contato periódico e pessoal para que os relacionamentos de confiança se fortaleçam e a Empresa Virtual se concretize.

e) A confiança precisa de liderança: Apesar de não haver necessidade de os membros de uma Empresa Virtual serem coordenados, existe a necessidade de um liderança não fixa, mas condicionada ao líder mais apropriado para cada situação específica.

Uma das principais características da Empresa Virtual é seu caráter provisório ou temporário e o fato de que suas fronteiras com o meio ambiente não serem completamente definidas. Uma condição para sua existência, definida em SIEBER (1997), é a qualidade que seus membros devem possuir, denominada de virtualidade. A virtualidade seria a qualidade que uma empresa, (Tal como as proposições de PORTER, 1992, enquanto processo de negócio gerador de valor para seus clientes, procurando obter um desempenho superior através de uma diferenciação de mercado em preço ou produto), possui em adquirir e manter suas competências fundamentais (tal qual definido em HAMEL \& PRAHALAD, 1994). As demais competências não essenciais serão obtidas externamente por meio de uma estrutura organizacional em cooperação com outras empresas, o que constitui por fim uma Empresa Virtual.

Esta complementaridade entre empresas e sua ação conjunta conduz à uma situação de eficiência e eficácia conjuntas e também uma otimização de fonte de recursos com as empresas participando de empreendimentos sem necessariamente ter entrado com todo o investimento requerido. Um exemplo típico é dado pelas franquias e pela terceirização.

Uma característica importante no relacionamento das empresas participantes de uma Empresa Virtual é o fato de o engajamento ser voluntário mesmo tendo em vista a possibilidade de ocorrência de pressões geradas por dependências econômicas entre 
empresas da rede. Mas de modo geral a relação deve ser do tipo ganha-ganha e geradora de sinergias. O que se tem verificado nos últimos anos, segundo SIEBER (1997) é a substituição em vários segmentos (exemplo da indústria automotiva e seus fornecedores e a indústria têxtil e seus distribuidores) do modelo de empreendimentos verticalizados, para a atuação de empresas horizontalmente organizadas em redes, coordenadas na maioria das vezes por empresas multinacionais. O processo de geração ou criação de valores está cada vez mais sendo executado por pequenas e médias empresas ligadas em rede, algumas delas desconhecidas dos consumidores.

Nos sistemas baseados em Empresas Virtuais, o papel dos coordenadores da rede é crucial pois eles controlam o fluxo de informações, possuindo a capacidade de organizar este fluxo de forma sistemática, independentemente de sua complexidade. Segundo SIEBER (1997), tem sido verificado que a complexidade do fluxo de informações nas Empresas Virtuais se revela menor do que nos empreendimentos verticalizados.

A empresa principal que era originalmente verticalizada passa a incorporar habilidades relativas a operação virtual assumindo tarefas de coordenação e informação e se tornando um membro funcional da Empresa Virtual denominado "broker". Ocorre uma retenção por parte da empresa líder das competências essenciais (core competenses) atuando como um broker nas atividades mais marginais. Um exemplo lembrado freqüientemente é o fornecido pela empresa Microsoft que conserva a atividade de desenvolvimento de softwares externalizando demais atividades de negócio tais como, marketing, produção, vendas, distribuição, reservando-se no entanto o direito de realizar inspeções de qualidade nestas atividades externalizadas.

Uma outra modalidade de Empresa Virtual é aquela constituída apenas por pequenas e médias empresas. Nesta modalidade, o estágio quatro é atingido diretamente sem se ter passado pelos outros três. Uma diferença importante é que neste padrão de rede de pequenas empresas existem vários centros de poder e não apenas um.

Tomando o exposto acima e de acordo com uma visão estratégica, existem três estágios de virtualidade pelos quais uma Empresa Virtual passa, e que servem para se estabelecer parâmetros de eficiência: eficiência em mercado, recursos, e em processos. Com 
relação ao mercado, o objetivo é buscar a cooperação com outras empresas com o intuito de otimizar a satisfação de necessidades, tais como massificação customizada, vendas compartilhadas e comunicação eletrônica de dados com os clientes. Busca-se também uma interação mais próxima com o cliente, fazendo-o parte da cadeia de valores ampliada (de acordo com definições encontradas em SHANK \& GOVINDARAJAN, 1994) e participando de maneira proativa com ele na criação e desenvolvimento de produtos ou serviços e de soluções, em uma verdadeira parceria.

Com relação aos recursos, a eficiência será medida dentro de um ambiente acima da simples aquisição de matérias primas ou produtos semi-elaborados. Parte-se para a integração dos recursos externos dentro do processo geral de geração de valor. São definidos importantes fatores tais como a escolha de fornecedores e utilização dos ativos. Ocorre uma redefinição de tarefas entre fornecedor e consumidor, chegando-se ao ponto de os fornecedores controlarem estoques dos seus clientes em uma integração e troca de informações que inclui o conhecimento do fornecedor do nível de vendas e de estoques do seu cliente, por exemplo, contudo existirá um certo cuidado por parte de uma empresa no sentido de esta não perder as competências essenciais para seus parceiros neste processo.

Finalmente, com relação aos processos de trabalho, a virtualidade é definida dentro de um contexto que se inicia com a eficiência de processos (administração eficiente) e evoluiu para a criação de uma competência em descentralizar a tomada de decisão. Isto se dá através do acesso dos trabalhadores a dados que lhes possibilite a autonomia de decisões, independência e responsabilidade, dissolvendo-se a hierarquia

A virtualidade é atingida pela concentração em competências essenciais, revisão dos processos de negócio e externalização ou complementação de atividades.

Em termos de necessidades de comunicação entre as empresas que amparem a Empresa Virtual tem-se a tecnologia de informação visando a integração como alvo principal e são destacados três aspectos: fluxos de informação automatizados através da linguagem direta entre as máquinas (intercâmbio eletrônico de dados), comunicação realizada entre grupos de trabalho e ligação entre várias redes locais com redes mais amplas. Em adição, devem ser satisfeitas as seguintes condições: A tecnologia de informação deve possibilitar a 
comunicação entre empresas de diversos níveis tecnológicos (empresas que se utilizam de computadores pessoais devem poder se comunicar com aquelas que funcionam com mainframes); as mudanças das empresas participantes de uma rede em resposta às mudanças de mercado devem ser passíveis de rápida implementação sem o comprometimento do funcionamento da rede e de sua segurança e o sistema de comunicação deve ser abrangente o suficiente de modo a atender as exigências de comunicação mencionadas acima.

Os atributos (alguns já mencionados) mais evidentes das Empresas Virtuais são :

- Existência cooperativa (mas independente) temporária com vistas a exploração de uma oportunidade de mercado.

- Flexibilidade e coordenação

- União que gera sinergia de competências fundamentais

- Utilização de tecnologia de informação

- Prática de transações baseadas em confiança

Voltando à definição de Empresa Virtual, esta se constitui em um negócio como qualquer outro, visando o fornecimento de produtos e serviços e utilizando-se de seus recursos, tais como pessoal, equipamentos, regras e procedimentos, buscando sobreviver no mercado através da maximização de seus lucros. O caráter virtual deste tipo de corporação se dá pelo fato de que as empresas que a compõem, para oferecer seus produtos e serviços, lançarem mão de recursos e conhecimento obtidos externamente, tanto quanto internamente. Assim uma Empresa Virtual é composta de várias empresas reais, que também podem ser denominadas de parceiras.

A concretização de uma Empresa Virtual e a própria virtualidade levam um tempo considerável, alguns anos de evolução e implementação interna nas empresas e entre as mesmas, constituindo-se num lento processo via de regra liderado por uma empresa que detenha um nível de influência ou uma capacitação especial. As motivações são as mais variadas: uma forma de redução de complexidades operacionais que dificultam a flexibilidade e reação rápida ou simplesmente uma resposta a exigências legais ou ainda um movimento no sentido de se reduzir incertezas principalmente em mercados instáveis. A Empresa Virtual 
não parece apropriada em mercados estabilizados e sem sofisticação tecnológica. Uma situação típica se refere ao desenvolvimento de mercados regionais onde a virtualidade possibilita uma sintonia mais rápida com os costumes locais.

\subsection{Gestão De Custos}

Os custos e seu registro/controle (contabilidade de custos) surgiram após a revolução industrial para adequar a mensuração, identificação e informação de custos, bem como a avaliação de estoques e apuração do resultado das empresas, ao advento da produção em larga escala realizada através de máquinas. Com isso, o cálculo do custo de qualquer produto vendido passa a ter de incorporar a totalidade dos fatores utilizados na produção.

Pode-se se definir custos como sendo qualquer utilização de recursos, representada em valores monetários e que se destina a produção bens e serviços, ou ainda segundo definição encontrada em MAHER \& DEAKIN (1994), o custo é um sacrifício de recursos sendo que quando se paga por algum produto, se está pagando pelo sacrifício que se deve fazer para adquiri-lo. Os autores fazem uma divisão básica em duas categorias de custos: os custos diretamente ligados produtos/serviços (outlaycosts), representados por saídas efetivas de caixa, ou sacrifícios explícitos relacionados aos bens adquiridos, mas quando não ocorrem saídas efetivas de caixa tem-se a segunda categoria representada pelos custos de oportunidade (opportunity costs), são o benefício que poderia ser obtido por um uso alternativo de determinado recurso este tipo de recurso, apesar de importante tem sido de certa forma ignorado pelas empresas em sua tomada de decisões.

Estes autores destacam ainda a importância de se diferenciar custos de despesas, sendo que enquanto os custos são sacrifícios de recursos, as despesas são recursos consumidos com o objetivo de se obter um resultado, só fazendo sentido dentro de uma dimensão de receita e confrontadas com as mesmas em demonstrações financeiras. Para os mesmos autores, a contabilidade de custos e seus efeitos par a tomada de decisões empresariais irá se preocupar fundamentalmente com os custos relacionados com o sacrifício de recursos. "The focus of cost accounting is on costs not expenses", (MAHER \& DEAKIN, 1994, p. 32) 
Dentro do contexto produtivo, o custo industrial se constitui em três fatores:

- Material Direto: composto pela matéria prima, embalagens e outros materiais e que pode ser apropriado diretamente aos produtos. O custo de material direto se divide em três categorias a saber: a matéria prima que sofre transformação no processo de fabricação e que em termos de quantidade possui o maior peso (ex.: tecido nas roupas); os outros materiais ou material secundário, que apesar de não ser o principal fator na composição do produto, ainda é facilmente identificável (botão de uma roupa) e as embalagens que são os materiais empregados no acondicionamento do produto para entrega, também são considerados dentro da categoria de materiais diretos devido a facilidade de identificação.

- Mão de Obra Direta: é a utilizada na fabricação de um produto (inclui salários e encargos) e definida como o custo do trabalho humano diretamente identificado e mensurável em relação ao produto e que atua no sentido de transformar o material direto em produto acabado.

- Custos Indiretos de Fabricação (CIF): engloba todos os demais gastos (custos indiretos) envolvidos com a produção, e que não se pode identificar diretamente com os produtos tais como alugueis, energia elétrica, depreciação mão de obra indireta (funcionários que não participam diretamente da produção). Estes custos são então rateados, segundo algum critério e assim apropriados/atribuídos aos produtos. Os critérios de rateio mais comuns são os que levam em consideração como base as horas de mão de obra utilizadas (horas homem) e o uso direto das máquinas (horas máquina) sendo que a escolha do critério deve ser feita de acordo com o insumo mais usado na produção.

Como exemplo de rateio de CIF tem-se, para o caso da base de rateio definida como horas máquina (em empresas altamente mecanizadas): Distribuição de um valor de R \$ $5.000,00$ para dois produtos. Supondo que o produto A consome $1.800 \mathrm{hs} / \mathrm{maq}$. e o prod. B 700 hs/maq. O rateio será:

Taxa de Absorção dos CIFs = Valor do CIF/ Critério de Rateio

$$
=5.000,00 / 1.800,00+700,00=\underline{\mathrm{R} \$ 2,00 / \text { hora }}
$$


Produto $\mathrm{A}=2 \times 1.800=3.600$

Produto $\mathrm{B}=2 \times \quad 700=\underline{1.400}$

Total de CIF 5.000

Por vezes, o cálculo do CIF não é tão simples assim, diversas empresas fabricam uma grande quantidade de produtos com várias fases de processamento em departamentos diferentes, surgindo a necessidade de se efetuar o rateio por departamentos (a chamada departamentalização) e depois aos produtos.

Voltando à equação referente ao custo dos produtos vendidos (CPV), tem-se que os mesmos podem ser definidos como sendo a soma dos custos incorridos na fabricação dos produtos que foram vendidos num determinado período. Neste momento o CPV se constitui em um elemento que contribui diretamente para o resultado da empresa sendo colocado nas demonstrações financeiras como parte integrante da demonstração de resultados.

A equação básica para se obter o valor do custo de produtos vendidos (CPV) é dada a seguir.

Inicialmente tem-se as seguintes relações :

CPV = Estoque Inicial + Custo de Produção - Estoque Final

onde,

Custo de Produção = Material Direto + Mão de Obra Direta + CIF

Combinado as duas equações acima, se obtém a fórmula completa de CPV:

$$
\mathrm{CPV}=\mathrm{CP}+\mathrm{EIPA}-\mathrm{EFPA}+\mathrm{EIPP}-\mathrm{EFPP}
$$

Onde:

$\mathrm{CP}=$ Custo de Produção

EIPA $=$ Estoque inicial de produtos acabados 
$\mathrm{EFPA}=$ Estoque final de produtos acabados

$\mathrm{EIPP}=$ Estoque inicial de produtos em processo

$\mathrm{EFPP}=$ Estoque final de produtos em processo

A fórmula acima pode ser simplificada apurando-se inicialmente o Custo de Produtos Acabados, que se obtém pela soma :

$\mathrm{CPA}=\mathrm{EIPP}+\mathrm{CP}-\mathrm{EFPP}$

Com isto, a fórmula de CPV é simplificada para:

$\mathrm{CPV}=\mathrm{EIPA}+\mathrm{CPA}-\mathrm{EFPA}$

Em resumo, tem-se as etapas de apuração do CPV segundo o esquema a seguir:

- separação entre custos e despesas

- separação entre custos diretos e indiretos

- apropriação dos custos diretos aos produtos

- rateio dos custos indiretos aos produtos.

Com relação à apuração de custos, a mesma é feita mediante a utilização de um dos dois métodos existentes: Custeio Direto e Custeio por Absorção. Estes métodos diferem basicamente quanto a forma como são tratados os custos fixos. Quanto ao volume de produção os custos podem ser classificados em fixos - não variam em função do volume de produção, (ex.: aluguel da fábrica) - ou variáveis - variam em função da quantidade produzida, (ex.: matéria prima). É importante lembrar que se os custos fixos e variáveis forem tomados de forma unitária este comportamento se inverte, com os custos fixos variando inversamente à quantidade produzida e os custos variáveis permanecendo inalterados.

Voltando aos dois métodos de custeio, tem-se que no Custeio por Absorção todos os custos de produção são apropriados aos produtos, de forma direta tal qual os custos referentes a material direto e mão de obra direta ou de forma indireta como é o caso dos custos indiretos de fabricação. Este método está relacionando com os princípios gerais da 
contabilidade principalmente no que tange a confrontação de receitas e despesas onde as despesas do período são consideradas apenas se o custo de produção for referente a produtos que forem vendidos no período. Já no Custeio Direto, os custos fixos recebem o mesmo tratamento das despesas pois estes serão considerados despesas do período independentemente se os produtos forem vendidos ou não. Neste método não ocorre correspondência com princípios contábeis e portanto não é aceito sob o ponto de vista legal, sendo contudo, bastante utilizado para fins gerenciais produzindo uma série de relações amplamente utilizadas, tais como margem de contribuição, ponto de equilíbrio, grau de alavancagem, etc.

\subsection{Gestão Estratégica De Custos}

Nos últimos trinta anos, uma série de mudanças em conceitos fundamentais da contabilidade gerencial acabaram produzindo uma nova forma de se pensar a análise de custos, o que acabou tornando antigas práticas inadequadas. Esta nova visão possui um enfoque mais concentrado nos aspectos estratégicos da contabilidade gerêncial e de sua aplicação para análise de custos.

Mais recentemente, a partir da década de noventa, a sobrevivência das empresas passa a sofrer uma série de desafios impostos pela nova realidade da globalização. Segundo VELOSO (1995), especialmente para aquelas empresas não dimensionadas para a atuação global, a queda de barreiras comerciais trazida pela globalização e a competição com empresas globais com maior capacidade em termos de capital, experiência e marketing, põe em cheque a rentabilidade destas mesmas empresas, que passam a buscar uma reconfiguração estratégica.

Da mesma forma que houve uma transição da tradicional contabilidade de custos para a análise gerêncial de custos, tem-se uma nova perspectiva definida como Gestão Estratégica de Custos (Strategic Cost Managemant - SCM). O pano de fundo desta última evolução é o destaque crescente da estratégia na análise dos negócios. 
O que tem sido observado é que a gestão tradicional de custos tem como objetivo apenas identificar o impacto financeiro das diferentes decisões administrativas que ocorrem dentro de uma empresa. Já de acordo com a nova linha de pensamento representada pela Gestão Estratégica de Custos (SCM), através de um sofisticado entendimento da estrutura de custos de uma empresa, visa-se um contexto mais amplo, onde os elementos estratégicos são considerados na elaboração das informações de custos. Estes elementos são, por sua vez, utilizados para se desenvolver políticas de obtenção de um bom posicionamento competitivo e facilitar as atividades de planejamento e implementação de uma estratégia de negócios.

Inicialmente com relação ao SCM, tem-se uma concepção que não será adotada neste trabalho mas que, devido a sua importância para consolidação de conceitos e definições básicas sobre o tema, será exposta a aqui à título de introdução. Esta concepção está mais relacionada com a Gestão de Custos Baseada em Atividades - ABM (Activity Based Managemant) que tem no sistema de custeio ABC (Activity Based Cost) a sua espinha dorsal. De todo modo, a interpretação inicial desta concepção, principalmente no que tange aos fatores que geraram o ambiente propício ao desenvolvimento da conceituação da Gestão Estratégica de Custos, merece ser mencionada.

De acordo então com esta concepção, os sistemas atuais de custos e de controles gerenciais não atendem mais as novas necessidades de seus usuários. Segundo NAKAGAWA (1991), isto é devido ao fato de que estes sistemas, apesar de continuamente aperfeiçoados ao longo do tempo, foram desenvolvidos em um ambiente competitivo baseado quase que exclusivamente em controle de custos, totalmente diferente do que se observa atualmente, onde ainda não existiam as preocupações com a produção alinhada com a globalização dos mercados. Esta nova concepção de produção, também chamada de "produção de classe mundial", se constitui em um novo paradigma caracterizado pela busca da qualidade, da flexibilidade, do aperfeiçoamento contínuo e da eliminação de desperdício através da eliminação ou redução das atividades dentro da empresa que não agregam valor efetivo ao cliente.

A partir da década de 80 e chegando nos dias de hoje, o meio competitivo passa a se caracterizar pela mudança tecnológica, pelo acirramento da competição (global e local), pelo surgimento de tecnologia avançadas de produção - JIT (Just-in-Time) e TQC (Total 
Quality Control)-, pela expansão do processamento de informações e pela maior ênfase na importância da produção enquanto fator de sucesso competitivo. Estas características "ambientais" não combinam mais com os tradicionais sistemas de contabilidade gerêncial. Portanto, uma série de conceitos fundamentais, dentre os quais, a apropriação de custos aos produtos e serviços estariam necessitando de uma revisão. Estes sistemas da forma como estão desenhados, não estão mais proporcionando a informação precisa e oportuna necessária (especialmente quanto ao processo produtivo) para que as empresas realizem suas operações e tomem suas decisões tendo em vista esta nova realidade.

A questão da gestão e mensuração dos custos torna-se crucial pois, de acordo com a já mencionada filosofia de classe mundial, não haverá mais lugar para empresas que não estejam direcionadas para as novas tecnologias avançadas de produção e de gestão empresarial e para a geração de valor ao cliente com qualidade. Esta nova realidade traz em si um novo padrão de interpretação e tratamento do comportamento de custos e em oposição a este padrão, a gestão tradicional de custos não está preparada para tratar de forma adequada as informações e gerar as mesmas informações de forma precisa para a tomada de decisões.

Uma das transformações observadas na estrutura de custos e que ilustra bem este problema tem a haver com a perda de participação dos custos com mão de obra direta e com materiais na composição do custo total do produto. Por outro lado, tem-se "o aumento de relevância dos custos indiretos de fabricação como depreciação, gastos com engenharia e processamento de dados, ferramentaria, manutenção, produtos em processo e tecnologia" (NAKAGAWA, 1991, p. 34). Surge a partir desta constatação um problema com as bases de rateio destes custos indiretos de fabricação. Quando estes custos representavam apenas um parte menor do custo total, talvez fizesse sentido alocá-los aos produtos apenas com base em critérios de volume de produção. Assim, por exemplo, quanto maior volume de um determinado produto, maior porção do custo indireto de fabricação total seria atribuída ao seu custo unitário tendo-se com base para esta atribuíção, as chamadas horas-máquina ou horas de mão de obra.

Após as alterações de participação entre custos diretos e indiretos (aumento da participação dos custos indiretos no custos totais de produção) apontadas acima, esta forma 
restrita e limitada de rateio não fornece mais as informações necessárias e precisas para a tomada de decisões, gerando distorções com relação aos verdadeiros custos unitários de cada produto, podendo com isto levar a erros sérios de apuração de custos e consequentemente de gestão. Com custos indiretos hoje consideravelmente maiores em termos proporcionais e absolutos na composição do custo de um produto, torna-se uma prática arriscada distribuir estes custos sob a forma de rateio, baseando-se única e exclusivamente este rateio em termos de volume de produção (quanto maior o volume de produção de um produto, maior a parcela dos custos indiretos de fabricação totais que este produto irá carregar no seu custo unitário). É preciso agora considerar neste cálculo outras variáveis tais como a complexidade de se produzir este produto (ou serviço), a participação deste produto na produção total e no mercado, etc.

Outro aspecto a ser considerado segundo, NAKAGAWA (1991), é o fato de que o custeio tradicional se preocupa com questões relativas a mensuração e avaliação dos estoques, bem como elaboração de informações para demonstrações contábeis e que, segundo o mesmo autor, continuarão a cumprir um papel importante dentro das organizações em termos de se avaliar o resultado ou desempenho das decisões. Mas com isto se conclui que o enfoque tradicional de custos está mais voltado para os aspectos internos de uma organização, ou seja, um enfoque mais direcionado para o registro e determinação de custos e para o controle e tomada de decisões. Aqui tem-se uma preocupação quanto ao rateio de custos, ao comportamento estrutural de custos totais e aos custos de cada produto em um determinado período, e então os custos são discutidos em termos de margens de contribuição, ponto de equilíbrio e índices de alavancagem operacional.

Segundo NAKAGAWA (1991), a preocupação com relação aos custos em termos mais externos à empresa se dá de forma tímida sob a forma da determinação de preços de venda e decisões de se comprar ou produzir. Entretanto, questões relativas a diminuição e otimização dos custos e de sua relação com o planejamento geral e estratégico de uma organização passam a partir de agora a ser tão importantes quanto os aspectos cobertos pela gestão tradicional de custos já mencionados.

Tentando responder a estas questões, começam a surgir estruturas analíticas que relacionam as informações contábeis com a estratégia gerêncial das empresas. Esta nova 
concepção denominada Gestão Estratégica de Custos, de acordo com a visão de alguns autores dentre os quais NAKAGAWA (1991), está voltada para outros aspectos que guardam uma relação estreita com as mudanças organizacionais trazidas pelo advento da globalização, tais como: aperfeiçoamento contínuo, concentração em atividades que produzem efetiva geração de valor para o cliente, metas e condicionantes de custo ditadas pelo mercado (e não mais por fatores internos de custo), contabilidade e custos baseados em atividades.

O objetivo final da Gestão Estratégica de Custos é a produção de informações que possibilitem uma melhor utilização de recursos e tomada de decisões, proporcionando aos produtos e serviços das empresas melhor competitividade em termos de custos, qualidade e eficiência de operações em um mercado globalizado. Neste sentido, é preciso evitar a adoção de critérios de rateio dos custos indiretos de fabricação - CIF (custos relacionados com aspectos de informática, ferramentaria, produtos em processo e engenharia) baseados apenas em volume produzido, e após isto atribuir os mesmos custos diretamente aos produtos. Os CIF devem ser atribuídos às atividades existentes na empresa, estas seriam as verdadeiras absorvedoras de custos e depois se deve alocar estas atividades aos produtos e serviços. Para-se isto utiliza-se uma das ferramentas mais importantes da Gestão Estratégica de Custos: o sistema de custeio baseado em atividades (Activity Based Costing - ABC).

O que se afirma é que sem o suporte proporcionado pela Gestão Estratégica de Custos dificilmente uma empresa conseguirá atingir a eficiência necessária para se tornar um produtor de classe mundial, pois as informações precisas de custos se tornaram fundamentais para se tomar decisões relativas à melhor utilização de recursos existentes. Contudo, segundo o que observa NAKAGAWA (1993), ainda existe uma certa dificuldade em se encontrar um modelo de análise e implementação de Gestão Estratégica de Custos, dificuldade esta ainda relacionada ao caráter recente deste tipo de concepção.

\subsubsection{Direcionadores de custos}


Relacionada com a Gestão Estratégica de Custos, a Gestão Baseada em Atividades (Activity Based Management-ABM) procura fornecer condições para a tomada de decisões com base nas atividades desenvolvidas pela empresa pois seriam estas os verdadeiros fatores que consomem recursos e portanto o cerne de qualquer análise de custos.

Uma das principais ferramentas do $\mathrm{ABM}$ é o custeio baseado em atividades, ou custeio ABC (Activity Based Costing). A diferença fundamental deste sistema dos tradicionais se deve ao fato de que sua base de alocação de custos são as atividades da empresa e não fatores baseados no volume de produção tais como horas-homem ou horasmáquina. Ao invés de se utilizar de critérios de rateio de custos baseados em volume de produção e que muitas vezes se revelam geradores de distorções, o custeio ABC utiliza-se de um instrumento chamado "cost driver" ou direcionadores de custo.

O que faz com que uma empresa atinja seus objetivos são as atividades empreendidas pelos seus diversos setores. São elas que caracterizam os acontecimentos e fatos que ocorrem dentro de uma empresa. Com isto, a contabilidade e a gestão por atividades visam colher informações relativas ao desempenho das atividades essenciais de uma empresa gerando assim informações para tomada de decisões. Os defensores desta nova visão defendem que a contabilidade tradicional não possibilita elementos tão adequados para isto.

Assim, segundo a filosofia existente no sistema ABM, o sistema ABC objetiva também a geração para os administradores de empresas de elementos para a tomada de decisões precisas e ágeis e o instrumento principal para que se atinja esta qualidade de informações é o chamado direcionador de custos. Segundo (NAKAGAWA, 1994), o ABC se constitui em uma ferramenta projetada e direcionada para análise estratégica. $\mathrm{O} A B C$ mostra uma visão de negócios, processos e atividades, que são de relevância imediata para a competitividade empresarial. São destacadas as oportunidades de otimização de retornos estratégicos proporcionada pelo consumo adequado de recursos, numa visão que o custeio baseado em volume não atinge. De acordo com o sistema $\mathrm{ABC}$, os direcionadores de custos são utilizados no controle dos custos indiretos de fabricação (CIF), relacionando estes custos às atividades e relacionando as atividades e seus custos finalmente aos produtos. 
Antes de se avançar na definição dos direcionadores porém, uma diferenciação se faz necessária. Os custos indiretos são rateados nos sistema de custeio tradicional, ao passo que o sistema $\mathrm{ABC}$ rastreia os custos incorridos nas atividades, através dos direcionadores de custos, bem como posteriormente as atividades consumidas pelos produtos. O sistema $\mathrm{ABC}$ critica o sistema tradicional baseado em volume afirmando que o rateio de custos indiretos obedece a critérios inadequados, gerando com isto distorções na apuração de custos dos produtos e consequentemente na tomada de decisões.

O advento do avanço tecnológico das últimas décadas causou uma alteração nos processos de produção caracterizada entre outras coisas por uma diminuição do peso da mão de obra direta e aumento dos custos indiretos de fabricação. Esta alteração causou um acirramento na distorção de custos implícita no rateio tradicional. Como já foi comentado acima, o sistema tradicional não leva em consideração aspectos como a quantidade de cada produto vendida, diversificação, complexidade e tamanho de produtos. Com isto, são atribuídos a determinados produtos custos maiores do que os efetivamente consumidos por estes mesmos produtos. Isto porque as bases que geram os critérios de rateio são definidas de acordo com aspectos nem sempre racionais e apropriados, refletindo inclusive posições pessoais dissociadas muitas vezes da realidade. Esta distorção prejudica a qualidade das decisões tomadas e por extensão a competitividade e o retorno do negócio. Já o sistema $\mathrm{ABC}$, diferentemente do atual, leva em consideração fatores como escala de produção e as utilizações de atividades diferentes para cada produto.

Mais especificamente, os direcionadores de custos são eventos ou transações que definem o custo de uma atividade por meio da quantidade de trabalho consumida nesta atividade e não apenas pela duração deste trabalho. Definidos também como todo fator que modifica o custo de uma certa atividade, os direcionadores de custos avaliam o desempenho das atividades e o seu consumo de recursos. Os direcionadores são ações que determinam "a quantidade de trabalho e através dela o custo da atividade " (NAKAGAWA, 1994, p.74) e são usados "para a descoberta de relações de causa e efeito nas incorrências de custos por parte de diversas atividades" (NAKAGAWA, 1991, p. 81). Com isto se consegue identificar aquelas atividades que agregam valor ao produto e as que não agregam e consequentemente atuar na redução de custos através da eliminação de desperdícios. Simplificando, todo fator que altere ou exerça algum tipo de influência no custo de uma atividade pode ser definido 
como direcionador de custo e a análise de direcionadores de custos significa o exame, quantificação e explicação dos efeitos dos direcionadores sobre as atividades.

Os recursos destinados à produção ou aos clientes - mão de obra, depreciação, materiais - são atribuídos pelo custeio $\mathrm{ABC}$ aos processos (produtivos ou administrativos) principais de acordo com direcionadores, estes processos são chamados de centros de atividades.

Os centros de atividades se constituem em processos homogêneos (de produção ou administrativos) e são divididos em centros cujos custos são atribuídos aos produtos e centros cujos custos são direcionados aos clientes de tal forma que se tem os custos dos respectivos centros de atividades sendo posteriormente consumidos pelos produtos ou clientes finais.

Nos sistemas tradicionais de custeio, os direcionadores mais utilizados são horas de mão de obra direta, matéria-prima, horas máquina e demais medidas baseadas em volume de produção. No sistema $\mathrm{ABC}$, os direcionadores podem ser, além dos já mencionados, número de inspeções, número de pedidos, ordens de clientes, etc. Devido ao fato de não considerar o volume como base de atribuição de custos, o $\mathrm{ABC}$ considera as diferenças de custos entre produtos decorrentes do fato de alguns produtos serem, por exemplo, mais complexos que outros e demandando portanto mais atividades. Uma diferença significativa que o ABC introduz é a chamada hierarquização de custos (custos que agregam e que não agregam valor ao cliente), sendo que esta hierarquização se realiza por unidade, por lote e por produto.

A determinação dos direcionadores é crucial para um custeio $\mathrm{ABC}$ bem sucedido. Os seguintes pontos são considerados:

- A variável deve ser quantificável e homogênea. Por exemplo, se a complexidade do trabalho é o direcionador escolhido, então devem ser definidos alguns fatores comuns de complexidade para se poder quantificar este direcionador.

- Os dados referentes às variáveis selecionadas podem ser coletados de modo efetivo quanto aos custos e associados a linhas de produtos 
- O direcionador selecionado deve guardar uma correlação forte com os níveis de custo no centro de custos da atividade. Ou seja, o comportamento do custo deve ser explicado com facilidade pelo direcionador ligado à ele

Na TABELA 1 abaixo, tem-se alguns exemplos de direcionadores de custos e sua relação com diversos centros de custos.

TABELA 1 - Relações entre centros de custos e direcionadores de custos

\begin{tabular}{ll}
\hline Centro de Custos & Direcionador \\
\hline \multirow{3}{*}{ Compras } & número de pedidos \\
& número de fornecedores \\
& quantidade de componentes \\
& tamanho do material \\
Materiais & número de movimentações \\
& \\
Controle de qualidade & número de inspeções \\
& tempo de inspeção \\
\hline
\end{tabular}

Alguns fatores que influenciam a seleção de direcionadores são a complexidade do "mix" do produto, o custo relativo das atividades agregadas ou a participação relativa de custos indiretos das atividades agregadas em termos de número de itens e seus fatores e por fim a disponibilidade de recursos na empresa.

Três fatores são determinantes para a aceitação de um direcionador: Complexidade do Produto (produtos diferentes consomem atividades diferentes e em diferentes proporções); Custo Relativo das Atividades (o quanto custa cada atividade em termos de percentagem do custo total de produção); Diversidade de Volume (produção de lotes de tamanhos diversos). 
Após selecionados, os direcionadores devem ser definitivamente escolhidos levandose em conta os seguintes aspectos:

- Facilidade de se coletar e processar dados relativos aos direcionadores. Os melhores direcionadores são aqueles cujos números sejam os mais fáceis de se obter

- O grau de correlação entre o direcionador e os custos incorridos deve ser próximo de 1 . Por ex., o número de pedidos atendidos deve ser proporcional ao montante de recursos consumidos para atendê-los. Em outro exemplo, se horas trabalhadas fossem um direcionador para a determinação de energia elétrica consumida pelas máquinas, os custos estarão distorcidos se os direcionadores não estiverem correlacionados com o consumo de energia elétrica. A medida que os custos relativos aumentam, aumenta a exigência do grau de correlação para se obter dados mais confiáveis.

- Efeitos comportamentais. Exemplo: se os custos indiretos da empresa são apropriados para área de vendas com base no direcionador número de clientes atendidos, os vendedores procurarão atender prioritariamente os clientes de grandes volumes devido ao seu maior pedido, deixando de lado os pequenos clientes

Em suma, o ponto central com relação aos direcionadores e ao próprio sistema $\mathrm{ABC}$, é a sua correta identificação (quais) e seleção (quantos). $\mathrm{O}$ fato de serem utilizados vários direcionadores de custos no sistema $\mathrm{ABC}$, é que o torna superior ao custeio tradicional que utiliza apenas de, no máximo, dois direcionadores. Contudo, em certos casos, devido à grande quantidade de atividades que compõem o sistema produtivo, elas são agrupadas em um único direcionador. Mas a rigor, quanto maior o número de direcionadores a serem utilizados no custeio, maior o grau de precisão atingida pelo mesmo.

\subsubsection{Cadeia De Valores}

Com relação aos conceitos originais relacionados à gestão estratégica e segundo a concepção de PORTER (1986), considera-se que escolher e implementar adequadamente uma estratégia competitiva genérica - seja custos, diferenciação ou enfoque -, será o caminho para uma empresa atingir uma vantagem competitiva sustentável. A vantagem competitiva de uma empresa, outro conceito desenvolvido por PORTER (1992), tem origem nas atividades que esta empresa efetua e que estão relacionadas com o projeto, produção, marketing, entrega e suporte de um produto/serviço. Cada uma destas atividades estará gerando ou contribuindo para que a empresa atinja uma vantagem competitiva sustentável, isto é, que 
seja permanente ao longo do tempo, em custos, diferenciação ou enfoque (enfoque em custos e em diferenciação). Dentro deste contexto, PORTER (1992) introduz o conceito de cadeia de valores. A cadeia de valores surge como um instrumento que possibilita a análise das atividades executadas dentro de uma empresa e como elas se relacionam entre si, contribuindo para que se identifique as fontes de vantagem competitiva para esta empresa. Pode-se também definir o conceito de cadeia de valores como o instrumento básico para se diagnosticar e intensificar esta mesma vantagem.

A cadeia de valores é definida como a representação em uma empresa das atividades genéricas que "são executadas para projetar, produzir, comercializar, entregar e sustentar um produto" (PORTER, 1992, p 33). Ela segmenta ou decompõe a empresa em atividades estratégicas relevantes, desde a matéria prima básica até o cliente final, facilitando assim o entendimento e a identificação das fontes potenciais de diferenciação, bem como a forma de minimização dos custos. De acordo com as premissas da estratégia competitiva de PORTER (1986), considera-se que a empresa que levar a cabo estas atividades da maneira mais barata e/ou mais diferenciada, estará gerando uma vantagem competitiva perante seus concorrentes, atingindo assim o sucesso.

Trabalha-se com o pressuposto de que a empresa se constitui em um conjunto de categorias genéricas, relacionadas com o projeto, produção, comercialização, entrega e sustentação do produto. A ferramenta para se representar estas atividades é a cadeia de valores e o modo como as atividades de uma cadeia de valores são executadas, se constitui na chave para se detectar a fonte de uma vantagem competitiva. Por exemplo, um sistema de distribuição física de baixo custo ou um processo de montagem eficiente, geram uma vantagem de custos, ou ainda a aquisição de matéria prima de alta qualidade ou um sistema ágil de atendimento a clientes criam fontes de diferenciação.

Nestas formas diversas de se executar as mesmas atividades é que residem as fontes básicas de vantagem competitiva. Portanto, e de acordo com os conceitos de estratégia e vantagem competitivas, o que interessa para uma empresa é, por meio de suas atividades, criar valores para seus clientes através da produção de produtos e serviços cujo valor se agrega à cadeia de valores destes e ao mesmo tempo excede os custos ligados à 
criação deste valor pela empresa tornando-a deste modo uma empresa de operações rentáveis.

Uma empresa e suas atividades pode ser então encarada como uma cadeia de valores ou um valor total gerado onde funcionam atividades de valor nas quais, de maneiras físico e tecnologicamente distintas, é criado o valor sob a forma de produtos valiosos para os compradores. Existe ainda uma margem, que se constitui na diferença entre o valor total criado e o conjunto de custos de execução das atividades de valor dentro da referida empresa. Em outras palavras, uma cadeia de valores é constituída de um valor total que se reparte em rentabilidade para empresa, daí a necessidade de o seu montante exceder os custos necessários para a sua criação (a mencionada margem), e o valor efetivamente transferido para o cliente sob a forma de produtos e serviços.

É importante destacar que PORTER (1992) chega a mencionar que a cadeia de valores por sua vez se insere em um sistema mais amplo, denominado de "sistema de valores" (PORTER, 1992, p. 31) e que inclui as cadeias de valores dos fornecedores, compradores e distribuidores de uma empresa.. Portanto, além da adequada compreensão de sua própria cadeia, a obtenção e sustentação de uma vantagem competitiva por uma empresa passa também pela adequada compreensão do sistema de valores no qual ela está inserida. De outro lado, o mesmo autor afirma que "uma cadeia de valores a nível de setor ou da indústria é demasiadamente ampla, porque pode encobrir importantes fontes de vantagem competitiva" (PORTER, 1992, p. 34).

Assim, recomenda-se em PORTER (1992) que se faça uma separação entre as cadeias de valor de uma empresa e as de seus fornecedores e distribuidores, pois as respectivas margens tomadas separadamente carregam informações importantes para o custo total do produto, fazendo parte dos custos e valores totais gerados em função dos compradores.

A cadeia de valores de uma empresa e o modo como ela se comporta é fruto de uma série de fatores, tais como "sua história, sua estratégia, e sucesso na implementação"(PORTER, 1992, p. 33). Sendo assim, e admitindo que dentro de uma mesma indústria temos empresas com histórias e estratégias diversas, conclui-se que as cadeias dos 
concorrentes desta indústria freqüentemente serão diferentes apesar da aparente semelhança nas operações e produtos oferecidos. A VARIG e a TAM, por exemplo participam da mesma indústria, porém diferem em políticas relacionadas com serviços de bordo, operações de embarque ou território geográfico atendido e portanto estão organizadas em cadeias de valores diferentes.

Outro fator importante e que será mais desenvolvido em outro item é o escopo competitivo, isto é, a amplitude em termos de setor, geografia, tipo de cliente, com os quais uma empresa e sua representação em uma cadeia de valores trabalham. O escopo competitivo pode ser inclusive uma fonte de vantagem competitiva na medida em que por exemplo, uma empresa ao explorar um determinado nicho de mercado, ou uma região geográfica mais restrita, sintoniza a sua cadeia de valores com este escopo, obtendo assim menores custos ou diferenciação que resultarão nesta vantagem.

\section{a) Atividades de Valor}

As atividades de valor são definidas em PORTER (1992) como atividades que se utilizam de insumos adquiridos, recursos humanos (mão de obra direta e gerêncial) e tecnologia específicas para completar seus objetivos, produzindo por outro lado algum tipo de informação (dados de um comprador, estatísticas diversas, etc.) ou ativos financeiros tais como estoques, contas a receber, etc. A partir deste ponto PORTER (1992) faz uma divisão entre atividades primárias e atividades consideradas de apoio.

As atividades primárias são as relacionadas com a criação física do produto, sua venda, entrega para o comprador e assistência após a venda. As atividades de apoio, como o próprio nome diz, apoiam as atividades primárias e a elas próprias com aquisição de insumos, tecnologia, recursos humanos e outras funções relacionadas com a infra-estrutura da empresa.

Antes de identificar os tipos de atividades de valor, é importante reforçar que as cadeias de valores das empresas são conjuntos distintos que geram vantagem competitiva. Tem-se então que, de um lado, o modo e o gasto de na realização de uma atividade, definirá a situação de custos perante a concorrência e de outro lado também o modo de execução de 
uma atividade irá determinar em que nível as necessidades de um comprador estão sendo atendidas e, portanto qual o nível de diferenciação nesta atividade. Assim, ao se comparar cadeias de valores distintas, existem condições de se verificar a vantagem competitiva de uma empresa diante da concorrência.

As atividades primárias se dividem em cinco categorias genéricas, a saber:

- Logística Interna: atividades relacionadas com recebimento, armazenamento e distribuição de insumos no produto. Ex.: controle de estoques, armazenagem, programação de frotas.

- Operações: atividades relacionadas com a transformação dos insumos no produto final. Ex.: trabalhos nas máquinas, montagem, embalagem, manutenção de equipamentos e operações de produção em geral

- Logística Externa: atividades relacionadas ao armazenamento e distribuição física do produto destinado aos compradores. Ex.: armazenamento de produtos acabados, processamento de pedidos e programação.

- Marketing e Vendas: atividades relacionadas com a condição de se oferecer uma forma através da qual o comprador possa adquirir os produtos e ser induzido a isso. Ex. propaganda, vendedores, cotação, seleção e relacionamento com distribuidores, fixação de preços.

- Serviços: relacionado ao fornecimento de serviços para reforçar e intensificar o valor do produto. Ex.: instalação, concerto, treinamento, fornecimento de peças.

Dependendo da área de atuação, uma ou outra atividade de valor primária terá mais ou menos importância para gerar as fontes de vantagem competitiva. Por ex., enquanto que, para uma lanchonete, as atividades de operações são cruciais, para um banco de empréstimos, as atividades de Marketing e vendas (habilidade dos gerentes de conta) assumem relevância mais importante, já para um revendedor autorizado de carros, a atividade de serviços é uma das fontes principais de vantagem competitiva. De todo modo, todas as atividades primárias estarão presentes dentro da empresa e possuem relevância para a vantagem competitiva de uma empresa. 
Quanto às atividades de apoio estas se dividem, segundo PORTER (1992), em cinco categorias:

- Aquisição: atividades referentes à compra de insumos utilizados na cadeia de valor da empresa (matérias primas, suprimentos, máquinas, equipamentos, etc.). Tem um significado diferente e mais amplo que o conceito de departamento de compras, estendendo-se por todas as atividades de valor da empresa e sendo acionada sempre que a ação for aquisição de insumos, máquinas e qualquer outro tipo de ativo, produto ou serviço. Possui importante influência para a vantagem competitiva de custo e diferenciação por exemplo em empresas de suco de laranja (aquisição de laranjas) ou empresas de aviação (aquisição de combustível ) .

- Desenvolvimento de Tecnologia: novamente é definido um conceito mais amplo do que apenas as atividades ligadas à $\mathrm{P} \& \mathrm{D}$, engenharia ou diretamente relacionadas ao produto final. Todas as atividades de valor dentro de uma empresa empregam algum tipo de tecnologia - conhecimentos, normas (preparação de documentos ou movimentação de mercadorias) ou tecnologia associada aos equipamentos, máquinas, processos e ao próprio produto. Em todos os setores estão sendo desenvolvidas novas formas de tecnologia visando em última análise a melhoria de produtos e processos mas nem sempre ligadas diretamente à estes fatores. Esta atividade de apoio pode estar suportando a cadeia inteira ou sendo desenvolvida em alguma atividade primária específica e se torna vital para a sustentação de vantagem competitiva em indústrias como as de produtos farmacêuticos ou de informática, por exemplo.

- Gestão de Recursos Humanos: envolve atividades de recrutamento, seleção, treinamento e desenvolvimento de todo o pessoal. Esta atividade também apoia as atividades primárias, as de apoio, bem como a cadeia inteira. Através de sua importância em questões como motivação, treinamento e qualificação de funcionários, a gestão de recursos humanos se torna fundamental para a vantagem competitiva em empresas de serviços como consultoria e auditoria onde é importante se ter uma metodologia de trabalho que seja bem compreendida por toda a empresa. 
- Infra-estrutura: referente à várias atividades tais como gerência geral, planejamento, finanças, contabilidade, setor jurídico e gerência de qualidade. Ao contrário das outras atividades de apoio, apenas sustenta a cadeia de modo geral e não as atividades primárias específicas, como as outras atividades de apoio também o fazem.

Uma outra divisão de atividades que se faz em PORTER (1992), no tocante ao papel desempenhado na vantagem competitiva é resumida a seguir, ressaltando-se que todas as atividades de valor tanto as primárias como as de apoio estão enquadradas nestas três categorias:

- Atividades diretas: envolvidas diretamente na construção do valor para os clientes, Ex.: montagem, fabricação, publicidade, recrutamento.

- Atividades indiretas: possibilitam a execução das atividades diretas, Ex.: manutenção, gerência de força de vendas, operação de instalações.

- Atividades de gestão da qualidade: garantem a qualidade das outras atividades Ex.: monitoramento, inspeção, testes, etc.

Em termos de construção e definição da cadeia de valores, (função já definida por PORTER como fundamental para se diagnosticar a vantagem competitiva), inicia-se com uma cadeia genérica com a identificação das atividades primárias e de apoio específicas de uma determinada empresa. Um critério importante é isolar atividades com economias e tecnologia diversas e uma forma de se efetuar isto é seguir o fluxo de produtos, papeis ou pedidos. Cada atividade primária ou de apoio pode, por sua vez, ser subdividida em outras atividades sendo que, para PORTER (1992), uma atividade deve ser considerada individualmente desde que obedeça os seguintes critérios básicos:

- As economias (estrutura de gastos, insumos e receitas se houver) devem ser diferentes

- Deve existir um impacto considerável relativo à diferenciação

- Deve representar uma parcela considerável do custo total 
A classificação das diversas categorias de atividades em atividades genéricas de valor deve seguir um critério de classificação tal que elas sejam alocadas (em termos de categoria genérica) onde a sua importância para a vantagem competitiva e o impacto competitivo estejam melhor representados. A rigor, tudo aquilo que é executado na empresa deve ser classificado dentro de uma atividade genérica de valor primária ou de apoio.

\section{b) Elos entre as Atividades}

Após a definição da cadeia de valores e de sua construção através do delineamento das atividades de valor que a compõem, PORTER (1992) introduz o conceito de elos entre as atividades como fontes importantes de vantagem competitiva. Parte-se do pressuposto que as cadeias de valores são um conjunto de atividades interligadas e não estanques e que, portanto, interagem entre si e se influenciam mutuamente.

O meio pelo qual as atividades se relacionam é chamado de elo. Por exemplo, em redes de distribuição de combustível (Esso, Shell, etc.), a adequada administração do recebimento e armazenamento do produto refinado oriundo das refinarias, otimiza a atividade de transporte e distribuição de combustível das distribuidoras para os revendedores.

Os elos são situações entre a forma pela qual uma atividade é realizada e a conseqüência disto para a eficiência e custo de outra atividade relacionada, - "A identificação dos elos é um processo de busca das formas pelas quais cada atividade de valor afeta ou é afetada por outras", (PORTER, 1992, p. 46) - a vantagem competitiva surge então dos benefícios da conseqüente otimização (por exemplo, especificações rigorosas de produtos possibilitando redução de custos) e coordenação (por exemplo, redução de estoques advinda da melhor coordenação da atividade de armazenamento), não só das atividades mas também dos elos entre elas.

Os elos surgem mais freqüentemente entre as atividades primárias e de apoio, por ex.: a atividade de aquisição afetando a qualidade dos insumos adquiridos e consequentemente os custos de produção. Mas também surgem entre as próprias atividades primárias Ex.: manutenção eficiente reduzindo o tempo de preparação de máquinas, ou 
entregas mais freqüentes para o comprador diminuindo estoques e contas a receber. A chave para identificar os elos é definir as formas pelas quais uma atividade é influenciada por outra ou vice-versa.

De qualquer modo, PORTER (1992) deixa claro que o objetivo de se buscar uma fonte sustentável de vantagem competitiva, passa necessariamente pela correta administração por parte da empresa, além das atividades de valor, também da identificação e administração dos elos existentes entre estas atividades - "A Vantagem Competitiva frequentemente provém de elos entre atividades da mesma forma que provém das próprias atividades individuais" (PORTER, 1992, p. 44).

Além dos elos existentes entre as atividades da cadeia de valores de uma empresa, existem os elos entre diversas cadeias especialmente quanto a fornecedores e distribuidores e compradores. Estes elos são chamados elos verticais e obedecem a mesma dinâmica de influência e interação dos elos internos. A atividade de aquisição de uma empresa, por exemplo, se relaciona com o sistema de pedidos do seu fornecedor. Neste caso, a idéia é a empresa e fornecedor reconhecerem possibilidades e vantagens decorrentes da otimização e coordenação dos elos entre estas atividades. O poder de negociação dos fornecedores, uma das cinco forças do sistema de estratégia competitiva preconizado em PORTER (1986), também é um fator a ser considerado na avaliação dos benefícios decorrentes dos elos entre cadeias.

Os elos referentes aos distribuidores obedecem à mesma lógica. Os distribuidores são os canais pelos quais passam os produtos das empresas, influenciando questões como preço, publicidade e vendas.

A otimização e coordenação conjuntas entre fornecedores, empresas e distribuidores para a exploração dos elos verticais se traduz em vantagens competitivas de custo e/ou diferenciação.

Quanto aos compradores, tanto empresas como unidades familiares (neste caso são consideradas as cadeias de valores de famílias representativas), possuem suas atividades e elos passíveis de serem explorados. Neste caso, se coloca em destaque o fator diferenciação 
e a origem desta diferenciação reside no valor e na vantagem competitiva (custos e/ou diferenciação) gerados pela cadeia da empresa fornecedora. O objetivo é explorar as interações possíveis entre as cadeias de compradores e empresa vendedora e como elas podem ser otimizadas para a empresa vendedora vencer a concorrência.

Com relação ao valor gerado para o comprador pela empresa, tem-se que "o valor é criado quando uma empresa cria vantagem competitiva para seu comprador - reduz o custo de seu comprador ou eleva-lhe o desempenho", (PORTER, 1992, p. 48). O modo como este valor é dividido entre ambos - um preço compensador para a empresa e bons lucros e vantagens para o comprador - se reflete na margem das empresas dentro da cadeia de valores e é derivado da estrutura industrial na qual elas estão inseridas.

\section{c) Escopo Competitivo e a Cadeia de Valores}

Outro conceito importante e que produz consequências para a vantagem competitiva e para a cadeia de valores, é o que PORTER chama de "escopo competitivo", (PORTER, 1992, p. 49). Este escopo delimita a estrutura e a economia (custos) da cadeia de valores e, portanto seu funcionamento.

As quatro formas de escopo que influenciam a cadeia de valores são:

- Segmento: tipos de produtos fabricados e compradores atendidos

- Verticalização: grau de execução interna das atividades, ou se as mesmas são feitas por outras empresas

- Geográfico: abrangência de regiões e países onde a empresa compete

- Industrial: variedade de indústrias relacionadas onde a empresa compete

Os escopos ou alvos variam também quanto à amplitude de atuação: Quanto mais amplo o escopo de atuação, melhor é a exploração dos benefícios decorrentes da realização de atividades internamente ou das inter-relações com cadeias de valores em diversos segmentos, ou ainda de áreas geográficas e indústrias afins Aqui a vantagem competitiva está relacionada com a otimização de recursos e redução de custos que uma maior 
abrangência de atuação possibilita. Por outro lado, estreitando o escopo, a cadeia de valores fica mais direcionada para o atendimento de um segmento específico (em termos de área geográfica, atividades executadas, indústrias afins, etc.), reduzindo custos ou explorando um atendimento mais especializado. Aqui a vantagem competitiva reside na melhor adequação do atendimento, estando mais relacionada com o fator diferenciação.

A estreiteza ou amplitude do escopo podem ser combinadas, sempre tendo em vista a questão da competitividade e da criação da vantagem competitiva sustentável. Uma empresa pode manobrar a sua cadeia de valores para, por exemplo, atender à um segmento específico de produtos - escopo estreito -, porém atuando neste ramo específico em nível mundial.

Em termos de escopo de segmento, PORTER (1992) tem a salientar que as diferenças entre os segmentos favorecem o escopo estreito e a estratégia de enfoque, porém as possibilidades de inter-relação, favorecem o escopo amplo, por ex., determinadas montadoras de automóveis com cadeias de valores distintas para carros grandes e carros pequenos mas, apesar das concepções diferentes, ocorrendo uma grande cooperação entre elas.

Já no escopo vertical quando a questão é decidir até que ponto a empresa pretende fabricar ou fazer fora, devem ser analisadas além das possibilidades de integração física, a integração em termos de atividades. Através da cadeia de valores, a empresa consegue perceber com mais clareza as vantagens e desvantagens de uma integração ou desintegração.

Com relação ao escopo geográfico, a vantagem de custos e/ou diferenciação pode ser obtida e intensificada através do compartilhamento e coordenação de atividades de valor, no atendimento de áreas geográficas diferentes. 


\subsubsection{Posicionamento Estratégico}

Antes de se tratar do objeto deste item e analisando a questão da gestão estratégica, é oportuno mencionar a contribuição mais recente de PORTER (1996) em artigo publicado na Harvard Business Review.

A questão estratégica deve ser tomada dentro da uma perspectiva competitiva originada no ambiente construído nas duas últimas décadas. Neste período e como já foi mencionado, a globalização, as novas tecnologias e as mudanças na sociedade conduzem à um ambiente mutável que exige da empresa uma flexibilidade crescente.

PORTER (1996) alerta para uma confusão que se faz entre a nova estratégia competitiva e a busca da eficiência operacional, sendo se observa um certo destaque desta em detrimento daquela. A eficiência operacional, representada pelas suas ferramentas tais como gestão de qualidade total, benchmarking (busca das melhores práticas), competição baseada no tempo, terceirização, alianças/parcerias, reengenharia e gestão de mudanças, é reconhecida como significativa e geradora de importantes melhorias, mas não elimina ou substitui a necessidade da verdadeira estratégia competitiva que visa a obtenção de um desempenho superior e a lucratividade sustentável e permanente de uma organização. Enfatizar unicamente a eficiência operacional implica no risco, de se colocar a empresa em uma posição competitiva inviável.

Em termos de opção estratégica, uma empresa deve superar seus concorrentes diferenciando-se deles do modo mais permanente possível, criando valores superiores para o cliente (liderança em diferenciação) ou os mesmos valores mas a um custo inferior (liderança em custos). A eficiência operacional e o posicionamento estratégico caminham juntos neste sentido sendo. Por exemplo, no caso da opção ser liderança em custos, a eficiência operacional propicia operar com baixo custo, mas o posicionamento estratégico garante a transferência para o cliente de valores superiores. 
É importante estabelecer que o cerne da vantagem competitiva se encontra nas atividades desempenhadas pela empresa para criar, produzir, vender e entregar seus produtos e serviços mas enquanto que a eficiência operacional significa realizar as atividades similares à concorrência de modo melhor, o posicionamento estratégico tem haver com a busca da realização destas atividades de formas diversas ou da escolha ou descoberta de novas atividades antes dos rivais. É preciso escolher uma gama diferente de atividades que por sua vez produzam uma composição única de valores. Por mais que uma empresa atinja a eficiência operacional, esta condição de ser diferente e consequentemente superior só será obtida através da prática da estratégia e de seu posicionamento.

PORTER (1996) coloca o posicionamento estratégico de uma forma diferente da adotada em trabalhos anteriores. Aqui o posicionamento estratégico, será condicionado por três fontes principais: o posicionamento voltado para a variedade de produtos e serviços (neste caso a empresa detém uma competência superior em uma determinada espécie de produtos e serviços através de um conjunto específico de atividades), o posicionamento voltado para a acessibilidade do cliente (baseado normalmente em termos de localização geográfica ou escala de produção) e por fim, o posicionamento para as suas necessidades (ocorre quando um conjunto de atividades consegue servir a um segmento específico de clientes de maneira eficiente). Seja qual for o foco deste posicionamento, este sempre emerge de um determinado conjunto de atividades que torna isto possível. Diferentes conjuntos de atividades irão determinar diversas formas de posicionamento.

Ao se definir o posicionamento, se redefine a estratégia como sendo a criação de uma posição única e valiosa, envolvendo diferentes formas ou conjuntos de atividades. O âmago do posicionamento estratégico para uma empresa será então a escolha de atividades que sejam diferenciadas por algum fator em relação as existentes e praticadas por seus concorrentes.

Voltando a atenção para as ferramentas do SCM, além da cadeia de valores e dos direcionadores de custos, a Gestão Estratégica de Custos de uma empresa se utiliza de seu posicionamento estratégico, e aqui novamente a contribuição de PORTER (1986) se faz presente. É definido este posicionamento de acordo com as duas formas básicas de 
competição que podem ser escolhidas por uma empresa: a competição baseada em custos baixos (liderança em custos) e a baseada em produtos mais sofisticados (diferenciação).

Cada uma destas formas de competir, trás em si formas e estruturas diversas de custeio e de sua contabilidade, bem como de práticas administrativas. Exemplificando, uma empresa que opera com posicionamento baseado em custos e dentro de um mercado mais amadurecido, ao investir em novos produtos, dará uma atenção especial aos custos-alvo planejados e sua variação com relação aos custos efetivamente observados. Já uma empresa direcionada para a diferenciação de produtos, participante de um mercado dinâmico e ainda em consolidação, os custos de fabricação tornam-se menos importantes. Para este tipo de empresa, será mais importante acompanhar os custos ligados à pesquisa e desenvolvimento (que normalmente não obedecem à risca limites préfixados) e não os custos de fabricação. Assim se reforça a idéia de que, dependendo do posicionamento estratégico da empresa liderança em custos ou diferenciação de produtos -, a análise e as perspectivas de custos serão diversas.

Surge uma discussão em torno da questão da estratégia e de sua relevância para a Gestão Estratégica de Custos. A premissa básica é a de que o processo de controle gerêncial de uma organização sofre a influência e é em grande parte determinado pela estratégia que esteja sendo implementada na mesma. Deste modo qualquer que seja o tipo de controle gerêncial existente, este deve guardar relação estreita com o tipo de estratégia que esteja sendo seguida. Os autores baseando-se em outros autores da área, produzem uma definição do conceito de estratégia como sendo "o processo através do qual os gerentes, usando uma projeção de cinco a dez anos, avaliam as oportunidades ambientais externas assim como a capacidade e os recursos internos afim de se decidirem sobre metas e sobre um conjunto de planos de ação para realizar estas metas “ (SHANK \& GOVINDARAJAN, 1993, p. 117). 


\section{A GESTÃo ESTRATÉgICA DE CUSTOS EM EMPRESAS VIRTUAIS}

\subsection{Definição de Critérios de Empresas Virtuais}

Uma causa para o surgimento de redes ou Empresas Virtuais se refere a uma certa desvantagem na verticalização diante das novas exigências da competição global por produtos customizados em massa com ciclo curto de vida e qualidade e atendimento ao cliente com preços competitivos. Esta desvantagem tem induzido as empresas a se concentrarem em capacitações e competências específicas gerando uma especialização e, com isto, uma busca por empresas complementares que detenham as demais atividades produtivas integrando-se assim em um trabalho coletivo e coordenado. Surgem então as redes de cooperação e mais especificamente as Empresas Virtuais, onde um fator crítico para o sucesso e se encontra na correta geração de informações para a decisão e análise de oportunidades.

O que definitivamente une as empresas em torno da formação de uma Empresa Virtual, é a complementaridade potencial existente entre elas, sendo que a viabilidade desta complementaridade surge com a possibilidade da exploração de alguma oportunidade que lhes 
é apresentada pelo mercado. O fato de atuarem em conjunto lhes dá melhores condições competitivas de enfrentar a concorrência e as exigências de flexibilidade e rapidez do mundo globalizado.

Para a definição geral dos critérios de Empresas Virtuais, foram adotados dois modêlos. Em termos de definições gerais, é utilizada a visão de Empresa Virtual existente na descrição da nova tendência estratégica denominada dinamismo e introduzida em GOLDMAN; NAGEL; PREISS (1995) (já descrita na Revisão de Literatura). No que tange aos critérios relativos ao funcionamento organizacional das Empresas Virtuais, foi adotada a estrutura operacional definida em GORANSON (1995) e que divide a Empresa Virtual em uma reunião de processos que guardam relação com o ciclo de vida da mesma. Este arranjo será descrito a seguir.

Recorre-se à contribuição existente em GORANSON (1995) para a definição de Empresa Virtual. Neste modelo, a Empresa Virtual é definida como um conjunto de processos classificados de acordo com o estágio de evolução da sua criação. A Empresa Virtual pode ser definida como uma reunião de organizações em torno de uma oportunidade sendo que estas empresas trabalham juntas visando um objetivo comum. Algumas modalidades de Empresa Virtual tem sido identificadas:

- Uma reunião em resposta a uma oportunidade. É considerada a forma mais típica. Inicia-se quando uma organização individual percebe uma oportunidade ou uma mudança de mercado que exigem uma série de competências. Esta organização então aglutina e lidera a formação de uma rede com parceiros que possuam as competências essenciais requeridas e se complementem para atender as exigências.

- Uma reunião menos temporária de competências fundamentais que já existia e se encontra a procura de oportunidades, eventualmente novos parceiros surgem e se juntam ao grupo devido a sua possibilidade de trazer novas possibilidades de exploração de oportunidades. Uma grande empresa e seus fornecedores pode ser considerada um exemplo deste tipo de Empresa Virtual.

- Uma cadeia de fornecedores que através de relacionamentos convencionais procura responder com agilidade às novas exigências de mercado 
- Um consorcio com as empresas se relacionando de modo mais convencional e que também procura responder com agilidade às exigências de mercado por meio de uma reunião de capacidades.

O que irá distinguir uma Empresa Virtual de um mero grupo de empresas é exatamente a capacidade deste grupo em atender com agilidade às exigências e mudanças de mercado muitas vezes inesperadas. E o aspecto que mais deve ser destacado é a sua formação e reformulação, mais até que sua operação, pois esta não se diferencia muito da operação normal de um negócio tradicional.

Em termos de estrutura, a Empresa Virtual é dividida em processos e não em funções, devido ao seu caráter eminentemente estratégico e sistêmico. Os processos por sua vez podem ser relacionados com a questão das decisões na medida em que as melhores atuações podem ser relacionadas com a qualidade das decisões tomadas e seus benefícios. Isto posto, a estrutura de processos de uma Empresa Virtual pode ser dividida em cinco atividades principais cada qual subdividida em atividades secundárias, organizadas de forma, até certo ponto, cronológica a saber:

\section{a) Identificação de Oportunidades}

É assumido que, em uma Empresa Virtual, uma organização (desempenhando o papel de líder ou não) ou um grupo de empresas ou capacidades ou ainda um broker (tal qual definido no item 3.1.1), devem estar voltados inicialmente para a identificação, definição e detalhamento de oportunidades. Normalmente, em uma Empresa Virtual, o mais provável é existência de uma das firmas (líder ou não) com uma competência essencial relacionada com a prospeção de oportunidades. Uma vez identificada a oportunidade, é missão desta empresa determinar as necessidades relacionadas com a mesma e relacioná-las com as características da Empresa Virtual já formada ou em formação.

a.1- Estratégia de Oportunidades: Uma estratégia voltada para a identificação de oportunidades deve estar presente na empresa que se propõe a realizar a tarefa de identificação de oportunidades. Esta estratégia deve ser suficientemente clara e explícita para 
os membros potenciais, porém suficientemente discreta para o ambiente externo de modo que informações importantes para o sucesso do empreendimento não cheguem ao alcance de competidores indesejados. Também deve ser explicitado a quem compete a liderança, pelo menos neste estágio. A estratégia básica estará relacionada com métodos de definição de competências essenciais e sua relação com possíveis oportunidades. Uma componente importante desta estratégia é a concepção de sucesso e a condição de determinar se a oportunidade é viável de ser explorada por uma Empresa Virtual.

a.2- Exposição: Afora a estratégia, que possui caráter analítico, devem existir ações concretas no sentido de sinalizar aos consumidores potenciais que haverá um movimento em direção a exploração de uma certa oportunidade. Se possível, o consumidor deve ser integrado neste processo. As mesmas ações promocionais devem ser empreendidas na direção dos parceiros potenciais.

a.3- Definição de Mercado: Ações no sentido de sintonizar o mercado, ajustando as necessidades que o mesmo apresenta com as competências essenciais existentes a nível da empresa e de seus possíveis parceiros. Trata-se até mesmo de auxiliar o nascimento de uma oportunidade e o início da abertura de uma interface com os clientes além de uma busca da solução para uma determinada demanda. A empresa líder acaba por participar e estimular o aparecimento de necessidades.

a. 4- Procura: Quando a oportunidade não é tão aparente tal como nos dois casos anteriores, deve existir uma ação de prospeção de novas maneiras de alavancar suas competências. Faz-se necessária a existência de um conjunto de processos/procedimentos orientados para mercados não tradicionais (por vezes com a agregação de novos sócios)

\section{b) Seleção de Parceiros}

Esta atividade costuma ocorrer em paralelo com a procura de oportunidades e a razão para isto está na redução dos custos relativos a construção e aprimoramento de parcerias. 
b. 1) Qualificação de Parceiros: Inicialmente é necessário se ter uma estratégia de definição de competências essenciais que uma oportunidade recém descoberta exige, e depois confidencialmente, identificar as competências de possíveis parceiros. Outros fatores a serem considerados para a qualificação de parceiros são qualidade, técnica, capacidade e recursos financeiros. Nesta atividade de definição da habilidade de uma empresa para integrar o grupo, a questão da confiança se torna importante.

b.2- História de Desempenho do Parceiro: O fator chave aqui é também é a confiança. Requer-se um método para se efetuar a comprovação da qualidade do possível parceiro e a ferramenta principal é o levantamento com base na história passada deste possível parceiro.

b.3- Busca de Parceiros: Esta se constitui na ação de busca de parcerias propriamente dita, sendo utilizados os instrumentos tradicionais como pesquisas em bases de de dados, meios de comunicação, contatos informais, etc.

\section{c) Formação}

Tendo identificado as oportunidades e parceiros, cumpre construir em detalhe o negócio e realizar os vários acordos e comprometimentos exigidos. É neste ponto que a maior parte dos recursos é requerida e comprometida

c.1-Desenvolvimento de Visão e Estratégia: A Empresa Virtual deve ser fundamentada em princípios explícitos que definam seus propósitos. A missão deve permear a atividade estratégica levando em consideração as características operacionais da Empresa Virtual, a sua capacidade de resposta às mudanças ambientais e sua agilidade para se antecipar às mudanças. Alguns outros componentes da visão são regras e metas. É importante se definir o quão arraigado está o desenvolvimento e implementação da visão entre os parceiros.

c.2- Seleção e Critérios de Parceria: Trata-se do detalhamento, em termos de regras, da busca e comprometimento de parcerias. Constituem-se em processos baseados 
em decisões de fazer ou não fazer. A necessidade é de se empregar recursos no fechamento das parcerias e comprometimentos com parceiros específicos o mais rapidamente possível.

c.3- Parâmetros do Empreendimento: O processo de formação de Empresas Virtuais depende de parâmetros para defini-lo e baseados em fatores financeiros e operacionais capazes de identificar e antecipar mudanças e problemas e determinar onde e como os objetivos podem ser atingidos.

c.4- Capitalização: Trata-se do detalhamento sobre como se dará a capitalização e a determinação de demais ativos para a operacionalização do empreendimento. Neste momento surge a necessidade de se criar uma infra-estrutura legal e financeira. Torna-se necessário também determinar um método para se avaliar a propriedade intelectual e dos demais ativos.

c.5- Exigibilidades de Produto: Determina-se aqui as responsabilidades de cada participante para o fornecimento de produtos e serviços.

c.6- Estratégias de Risco e Recompensa: os riscos e recompensas serão definidos em conjunto sendo que as recompensas deverão em principio ser proporcionais aos riscos, incluídos aqui os riscos relativos a imagem, negócio, nome, marca, conhecimento de mercado.

c.7 - Estrutura Operacional: Trata-se aqui da criação/definição da infra-estrutura operacional a ser usada na Empresa Virtual e no relacionamento de seus parceiros (atividades de supervisão, relato e comunicação). Tem-se aqui a definição da hierarquia entre os parceiros, além de regras de prevenção de conflitos e de atividade facilitadora do trabalho em equipe.

c.8 - Plano de dissolução: Desde o seu nascimento, a expectativa é de que as Empresas Virtuais sejam temporárias apenas com o objetivo de explorar uma oportunidade específica e que portanto deverão se desfazer em um prazo predeterminado com o fim da exploração desta oportunidade. Faz-se necessário um mecanismo de percepção de 
esgotamento da oportunidade e que aciona outro mecanismo de dissolução de acordo com este plano.

\section{d) Operação:}

Após formada, a Empresa Virtual inicia suas atividades propriamente ditas, ou seja sua operação. Esta atividade de operação poderá dar a impressão de uma empresa convencional, mas com algumas especificidades únicas, talvez com alguma semelhança com uma grande empresa de manufatura descentralizada.

d.1 Medidas de Desempenho: :stas medidas estão relacionadas com a estrutura de recompensa e risco já mencionada. Tem a finalidade de oferecer aos gestores uma visão da situação coletiva e individual que os possibilite um entendimento correto das condições dinâmicas de suas operações.

d.2 Relações com os Clientes : A Empresa Virtual deve parecer aos olhos dos clientes uma coisa só. Esta transparência deve estar suportada pelos processos adequados. Presume-se que boa parte da estruturação do sistema de risco e recompensa deve estar baseada na satisfação do cliente.

d.3 Práticas de Operação: Após estar funcionando, uma Empresa Virtual deve parecer uma organização unificar. As diferenças e fronteiras entre seus componentes devem ser subordinadas ao trabalho conjunto. Trata-se de uma visão que esteja acima da mera administração das fronteiras entre as firmas participantes mas uma administração que encare a Empresa Virtual como um organismo coeso e não um grupo descentralizado de empresas.

\section{e) Reconfiguração e Dissolução}

Em algum momento um certa oportunidade se modifica ou segue para outra direção. De acordo com esta premissa, a Empresa Virtual deverá possuir a capacidade de se reconfigurar ou mesmo se desfazer rapidamente. 
e.1- Identificação de Necessidades: Nesta etapa, é posta em ação capacidade da Empresa Virtual de, após o correto monitoramento de oportunidades potenciais, se adaptar e se reinventar para poder explorar estas oportunidades.

e.2- Exigências Residuais: Após dissolvida ou reconfigurada, a empresa deve possuir a capacidade de identificar e se responsabilizar por possíveis obrigações residuais: empréstimos, obrigações trabalhistas, etc.

e.3- Dispersão de Ativos e Patrimônio: Composto por uma série de processos de distribuição de ativos (inclusive os intangíveis) e direitos entre os parceiros, que devem ser corretamente quantificados, inclusive mensuráveis em termos de custos.

Finalmente, devem ser mencionadas as funções de apoio relacionadas com a infraestrutura da Empresa Virtual, a saber: infra-estrutura física (plantas, logística, máquinas e equipamentos capacitações), legal (conjunto de regras, procedimentos e políticas), sóciocultural (cultura, habilidades, regras de negócio relacionadas com a supervisão, contexto político) e de informação (mecanismos usados para criar, gerenciar e comunicar informações dentro do empreendimento e para estabelecer a condução dos trabalhos).

\subsection{Definição de Critérios de Gestão Estratégica de Custos}

Além do novo arranjo empresarial representado pelas Empresas Virtuais, as exigências de competitividade e qualidade impostas às empresas de modo geral, acabaram fazendo com que dois aspectos - planejamento estratégico e gestão de custos - se combinassem, surgindo então esta nova e importante aplicação da área de negócios: A Gestão Estratégica de Custos - SCM. Existem razões para se acreditar que o SCM possui um importante papel dentro desta nova forma de atuação em Empresa Virtual, tanto quanto ao seu desenvolvimento como para a construção de vantagens competitivas necessariamente superiores e sustentáveis.

A gestão adequada de custos e consequentemente de recursos, propicia uma condição de tomada de decisões superior ao sistema tradicional. O objetivo é incrementar a competitividade empresarial que por sua vez é condicionada por parâmetros externos (economia, sociedade, infra-estrutura, concorrência, qualidade e relacionamento com 
fornecedores, distribuidores clientes e aliados, postura diante da concorrência) e internos (capacitação empresarial, competências específicas e fundamentais, estratégia adotada, qualidade de gestão, tecnologia, estrutura organizacional, condições gerais de máquinas e equipamentos, gestão e qualidade de estoques, reservas e gestão financeiras) ou ainda tangíveis (máquinas e tecnologia) e intangíveis (qualidade de gestão, relacionamento com os clientes).

$\mathrm{Na}$ verdade, tem-se que a análise tradicional de custos tem dado mais atenção aos condicionantes internos e tangíveis ou seja, ao registro, determinação e rateio de custos indiretos, gerando informações para tomada de decisões cujos determinantes são de origem quase exclusivamente interna e gerando discussões e análises em torno de margens de contribuição, ponto de equilíbrio e alavancagem operacional. Dentro desta concepção, o aspecto externo da análise de custos (representada pelos métodos de determinação de preços de venda ou a decisão clássica entre produzir internamente ou externalizar), e sua interação com os fatores externos fica relegada à um segundo plano. No ambiente globalizado e volátil das últimas décadas, onde a realidade inclui as mudanças constantes de rumo e de relacionamentos com fatores externos (fornecedores e clientes por exemplo), esta concepção de certa forma estática da análise de custos não fornece mais subsídios adequados para a tomada de decisões.

Uma das contribuições mais interessantes para a definição de um modelo de Gestão Estratégica de Custos com enfoque alternativo e que será a base de sistematização deste trabalho, é aquela introduzida em 1993 pelos professores J. SHANK e V. GOVINDARAJAN, em seu livro "Strategic Cost Managemant “ - SCM. Para estes pesquisadores, a análise de custos tradicional apenas avalia as consequências financeiras das possibilidades de decisão empresarial e não leva em consideração os elementos e objetivos estratégicos existentes na empresa. Já o SCM tem como um de seus princípios básicos a utilização dos dados de custos para a criação de estratégias de obtenção de vantagens competitivas sustentáveis, de acordo com a concepção de estratégia competitiva preconizada em PORTER (1989).

O principio básico e onde o SCM, segundo SHANK \& GOVINDARAJAN (1993) começa a se diferenciar do enfoque anterior, é o de que as questões e premissas 
estratégicas devem ser levadas em consideração pela contabilidade gerêncial de forma mais efetiva e explícita. Assume-se que nas últimas duas décadas a análise estratégica tem sido disseminada nas práticas de negócio acabando por influenciar todo o contexto dos negócios. Assim sendo, a análise estratégica não pode ficar relegada a um segundo plano em um tema tão importante quanto a gestão e contabilização de custos.

Tendo em vista que para SHANK \& GOVINDARAJAN (1993), a análise tradicional de custos se constitui em um processo de avaliação dos efeitos financeiros das diversas decisões tomadas por uma empresa, a diferença entre o SCM e a gestão tradicional é que a primeira possui um horizonte mais amplo, onde os "elementos estratégicos tornam-se mais conscientes, explícitos e formais (SHANK \& GOVINDARAJAN, 1993, p. 4). Associando-se os dados de custos ao planejamento estratégico, se atinge uma visão mais sofisticada da estrutura de custos de uma organização e esta visão seria a base da Gestão Estratégica de Custos. Para os autores já mencionados, o SCM é o uso gerencial da informação de custos dirigido explicitamente a um ou todos dos seguintes estágios do planejamento estratégico:

- formulação de estratégias,

- comunicação destas estratégias para a firma

- desenvolvimento de condições e táticas para a implementação das estratégias

- controles para monitoramento da implementação da estratégia desenvolvida

- controle de resultados da implementação da estratégia

Nesta visão, e de acordo com esquema acima, fica claro que a gestão de custos tem, a a partir de agora, a finalidade de ajudar no desenvolvimento e implementação de uma estratégia gerencial.

Extraídos da literatura sobre gestão estratégica e sofrendo posteriormente algumas adaptações, surgem três temas cujos elementos financeiros se misturam e se constituem nas três ferramentas básicas sobre as quais está estruturado o SCM, de acordo com SHANK \& GOVINDARAJAN (1993). As três ferramentas serão desenvolvidos em detalhe a seguir, sendo que, em cada uma destas ferramentas, a visão de custos recebe um tratamento diferente do tratamento tradicional, são as seguintes: 
a) Análise de direcionadores de custos

b) Análise da cadeia de valores

c) Análise de posicionamento estratégico

\subsubsection{Análise de Direcionadores de Custos}

A partir desta primeira aproximação e a partir de agora, de acordo com a visão da Gestão Estratégica de Custos, SHANK \& GOVINDARAJAN (1993) apresentam o conceito de direcionadores estratégicos de custos em uma visão ampliada, exposta a seguir.

Este termo que se constitui em um dos conceitos chave do sistema de custeio baseado em atividades (ABC), também é utilizado na obra de SHANK \& GOVINDARAJAN (1993) com esta mesma denominação porém com um significado mais amplo e estratégico. Ainda de acordo com a concepção do custeio ABC, os autores afirmam que "o custo é causado, ou direcionado, por muitos fatores que se inter-relacionam de formas complexas “ (SHANK \& GOVINDARAJAN, 1993, p. 21). Assim é necessário um entendimento do comportamento dos direcionadores de custos para se compreender o comportamento dos custos por unidade e como eles são determinados. De acordo com o conceito tradicional de custeio, o único direcionador de custos é o volume de produção, ou seja, o tamanho da produção irá determinar a forma de custeio e seu comportamento. Com a Gestão Estratégica de Custos, o volume de produção e outros conceitos derivados - ponto de equilíbrio, custo-volume-lucro, margem de contribuição, custos fixos versus custos variáveis, etc.- não são suficientes para explicar o comportamento dos custos nos dias de hoje.

Na verdade, os autores não negam que o volume é uma variável a ser considerada na análise estratégica de custos pois o custo médio realmente apresenta uma tendência de queda mediante um aumento de volume e assim "se uma empresa de alguma forma pode dobrar sua produção, ela pode conseguir uma vantagem de custos significativa que permita baixar os preços ou realizar mais gastos para obter diferenciação de mercado ou uma combinação das duas idéias“" (SHANK \& GOVINDARAJAN, 1993, p. 192). 
Por outro lado, estes mesmos autores observam que existem casos concretos nos quais o volume não é suficiente para explicar as alterações no custo por unidade, bem como definir o sucesso estratégico de uma empresa: "se ser o maior significasse sempre custo inferior, por que a indústria do cimento, o setor de massas processadas e o setor de processamento de leite estão dominados por pequenas fábricas regionais ? ", (SHANK \& GOVINDARAJAN, 1993, p. 192).

$\mathrm{Na}$ Gestão Estratégica de Custos, outros direcionadores mais apropriados e de caráter estratégico estão presentes na literatura sobre gestão estratégica e são assinalados pelos autores. Segundo SHANK \& GOVINDARAJAN (1993) que por sua vez recorrem a terminologias de outros autores (RILEY, 1987), existiriam duas categorias de direcionadores estratégicos de custos: Os direcionadores estruturais que se constituem em escolhas estratégicas da empresa levando-se em conta as suas condições econômicas e que determinam (direcionam) o comportamento de seus custos e os direcionadores de execução que são aqueles executados pela empresa e cuja influência nos custos vai depender de como a empresa consegue executá-los, estes direcionadores estariam relacionados diretamente com a questão do desempenho (quanto mais melhor).

Segundo os autores, tem-se a seguinte relação de direcionadores:

\section{Direcionadores Estruturais:}

- Escala: Magnitude mínima de investimentos em produção, pesquisa e desenvolvimento e marketing para que se possa atuar em determinado setor

- Escopo: Nível de integração vertical, geográfica. setorial, etc.

- Experiência: Quantas vezes no passado uma empresa vem fazendo o que faz hoje

- Tecnologia: Quais tecnologias são utilizadas em cada processo.

- Complexidade: Amplitude da linha de produtos/serviços oferecida aos consumidores, possui uma relação com o custeio baseado em atividades (ABC).

Direcionadores de Execução: Envolvimento da força de trabalho (participação/melhoria contínua), gestão da qualidade total, utilização da capacidade, 
eficiência do lay-out das instalações, configuração do produto, exploração de ligações com fornecedores e clientes.

Estes direcionadores estratégicos de execução, ao contrário dos estruturais, estão diretamente relacionados com o desempenho, isto é, quanto mais intensidade na sua manifestação, melhores são as consequências sobre o desempenho da empresa. De todo modo, é importante ressaltar que torna-se cada vez menos relevante no curto prazo analisar as mudanças dos custos unitários decorrentes nas mudanças no volume de produção. Para se analisar custos sob o ponto de vista de tomadas de decisão estratégicas, é preferível avaliar a situação de custos relacionando-a com a posição competitiva da empresa em relação aos direcionadores acima mencionados, não restringindo esta análise aos custos fixos ou variáveis.

É oportuno colocar um exemplo relatado em SHANK \& GOVINDARAJAN (1993), o exemplo da montadora Ford versus a General Motors (GM) no período de 1982 a 1992, para justificar a importância da análise de direcionadores de custos para a estratégia de uma empresa.

Em 1981 a Ford estava em desvantagem competitiva perante a GM que a suplantava em direcionadores estratégicos-chave para o setor automotivo tais como integração vertical e escala de produção, prova disto é que se observava uma produção de veículos GM mais de duas vezes superior a da Ford. Também a GM superava a Ford em investimentos em novas tecnologias, um outro fator estratégico importante. Contudo os autores observam que em menos de dez anos a Ford reverteu a situação e se tornou mais lucrativa que sua rival

A reposta para esta reviravolta está em uma adequada análise de direcionadores de custos realizada pela Ford. A Ford percebeu que em um dos direcionadores estratégicos de custos a GM, não detinha superioridade. No direcionador complexidade da linha de produtos, a GM gerava deseconomias que superavam as economias advindas da escala, tecnologia, experiência e integração vertical. Na verdade, a linha de produção da GM possuia uma infinidade de variações de modelos através de inúmeras combinações de motores, pacotes opcionais, etc, que representavam milhões de possibilidades para os clientes. A quantidade 
era tão desproporcional que levaria milhões de anos para uma fábrica de tamanho padrão (escala mínima) produzir cada uma das possibilidades de modelos disponível na GM e muitas possibilidades de modelos jamais seriam produzidos.

Este grau desnecessário de complexidade fazia com que os custos de produção fossem se tornando excessivos e não compensadores. Diante disto a Ford partiu para uma estratégia de oferta de um número mais reduzido de modelos obtendo assim uma vantagem de custo por unidade em relação a GM.

Outra desvantagem da GM se localizava no direcionador de execução relacionado à qualidade de fabricação. A Ford, mediante um programa de qualidade, obteve ganhos significativos de custos unitários que a GM simplesmente não acompanhou. Após menos de dez anos, a Ford adquiriu uma posição nos direcionadores complexidade e qualidade que superou as vantagens da GM em escala, experiência e integração vertical. Com isto, se procura demonstrar " os benefícios estratégicos potenciais de se conhecer que fatores direcionam o custo e como usar a análise do direcionador de custos para obter vantagem competitiva." (SHANK \& GOVINDARAJAN, 1993, p. 210).

\subsubsection{Análise da Cadeia de Valores}

Após a descrição do conceito de Cadeia de Valores tal qual desenvolvido por PORTER (1992) na Revisão de Literatura, este conceito será ampliado sendo utilizada para isto a contribuição de SHANK \& GOVINDARAJAN (1993).

Em suma, a cadeia de valores tal como é preconizada em PORTER (1992), em que pese a alusão deste autor à necessidade de se enfocar a cadeia sob o ponto de vista mais amplo (sistema de valores), tal como já se mencionou anteriormente, parece mesmo assim 
padecer de uma limitação em termos de visão de conjunto ou sistêmica em relação ao conceito de cadeia de valores e de sua pertinência para a Gestão Estratégica de Custos SCM. Permanece o mérito da cadeia de valores como ferramenta estratégica de acordo com a concepção de PORTER (1992) como um instrumento básico para diagnosticar a vantagem competitiva e descobrir maneiras de criá-la e sustentá-la, porém é necessária uma abordagem mais ampla e sintonizada com em termos de SCM.

O conceito de cadeia de valores, introduzido inicialmente por PORTER (1985), foi adaptado por SHANK \& GOVINDARAJAN (1993) dentro de uma visão mais ampla e aberta, externa à empresa. Os autores exploram em mais profundidade uma dimensão da cadeia de valores onde PORTER chega a fazer uma menção quando se refere à inserção de uma empresa e sua cadeia de valores em um sistema mais amplo denominado "sistema de valores", e onde PORTER afirma que "a obtenção e a sustentação de uma vantagem competitiva dependem da compreensão, não só da cadeia de valores de uma empresa mas também do modo como a empresa se enquadra no sistema de valores geral" (PORTER, 1992, p. 31-32). Contudo não ocorre um aprofundamento desta concepção em termos de suas implicações estratégicas. Se faz necessário um novo enfoque, neste caso encontrado na contribuição de SHANK \& GOVINDARAJAN (1993). Este novo enfoque está mais sintonizado com as condicionantes externas do SCM, encarando a da Análise da Cadeia de Valores como uma ferramenta integrada com o ambiente externo e com as possibilidades de articulações entre empresas diversas, a exemplo das Empresas Virtuais.

Considera-se (com mais ênfase do que em PORTER), uma empresa como um conjunto de atividades típicas que criam valor, iniciando-se desde a produção de matérias primas mais elementares, até o fim da cadeia representada aqui pelo consumidor final, sempre abrangendo diversas empresas que sejam participantes desta cadeia de valor geralmente de forma horizontal. Trata-se de uma visão oposta ao conceito tradicional de valor agregado adotado pela contabilidade gerencial ainda nos dias de hoje. A perspectiva de valor agregado tem seu início nas compras junto a fornecedores e termina nas vendas aos consumidores imediatos (sejam eles intermediários ou finais), sendo que o principal objetivo é maximizar esta diferença (valor agregado) entre compras e vendas. 
O conceito ampliado de cadeia de valores ultrapassa ambos os lados da equação acima mencionada. Os fornecedores e os fornecedores dos fornecedores destes devem ser também contabilizados no processo com relação a custos para a cadeia como um todo, o mesmo raciocínio valendo para a perspectiva dos consumidores. A análise de custos com esta visão estratégica expandida, passa a levar em consideração as possibilidades de exploração de oportunidades e ligações com fornecedores e consumidores.

A forma de administração de custos sob a perspectiva estratégica requer uma visão mais ampla e externa à firma, sendo que este novo e mais amplo enfoque tem como uma de suas ferramentas a cadeia de valores. Os autores buscam também em PORTER os conceitos mais básicos de formas de concorrência - custos, diferenciação e enfoque -, dando um destaque especial para a ferramenta cadeia da valores neste processo - "Se uma empresa pode ou não desenvolver e manter uma diferenciação ou vantagem de custo ou diferenciação com vantagem de custo (como os japoneses demonstraram) depende fundamentalmente de como a empresa gerencia sua cadeia de valor em relação às cadeias de valor de seus concorrentes" (SHANK e Govindarajam, 1993, p.61).

Quanto a vantagem competitiva, esta é gerada se a empresa repassa um valor superior ao cliente ao mesmo custo (diferenciação) ou um valor equivalente a custo mais baixo (custos) e a análise baseada na cadeia de valores irá dizer à empresa em que ponto da cadeia de valores de seu cliente um valor maior ou um custo menor podem ser produzidos.

Cada negócio seria uma parcela, mas somente uma parcela, de uma grande cadeia de valores que se inicia (para se chegar à um extremo de análise), desde a tabela periódica dos elementos até o fim definitivo e até depois disto inclusive, através das novas possibilidades decorrentes da reciclagem. Cada firma deve então ser compreendida dentro de uma contexto ampliado de cadeia de valores (e atividades criadoras de valor) o mais "globalizadamente" possível. Atividades estas que criam valor e das quais a empresa é apenas uma parte. É preciso então que esta firma entenda muito profundamente a natureza da cadeia de valores ampliada na qual ela se insere, analisando-se para trás (em direção aos fornecedores e se for preciso, aos fornecedores dos fornecedores) e para frente (até o consumidor final, mesmo que não diretamente), pois, no caso do consumidor final, este irá em 
última análise pagar por todas as margens de lucro praticadas dentro da cadeia por seus diversos participantes.

Conclui-se que a forma como as empresas traçam suas políticas de diferenciação de produtos e/ou liderança em custos depende em muito de como um empresa manobra a sua cadeia de valores em relação aos seus concorrentes mas também depende da exata compreensão de todo o sistema de valores e não somente da cadeia de valores da qual esta empresa é constituída.

Fornecedores e clientes e fornecedores de fornecedores e clientes de clientes têm margens de lucro que são também importantes na análise e, possuindo a visão ampliada da cadeia, as empresas são capazes de identificar possibilidades de integração ou desintegração tanto para frente (em direção aos compradores) como para trás (em direção aos fornecedores) e de tomar decisões estratégicas mais condizentes com a nova realidade empresarial competitiva.

Para melhor ilustrar o conceito ampliado de cadeia de valores existente em SHANK \& GOVINDARAJAN (1993), tem-se a FIGURA 1 (página 116), extraída do livro dos mesmos autores, e que apresenta uma cadeia de valores conceitual para a indústria de papel. As diversas atividades de valor tais como reflorestamento, corte e envio das toras, produção de celulose, produção do papel e produção de produtos derivados (conversão), são aquelas pelas quais a indústria cria um produto valioso para seus compradores finais .

É possível quantificar o valor criado em cada estágio, identificando os custos, rendimentos e ativos para cada atividade. A idéia é que cada firma - A, B, C, D, E, F, E G - , algumas mais integradas e outras especialistas mais estreitamente enfocadas, deve construir uma cadeia de valores global para a indústria na qual está inserida, desagregando o valor total da cadeia em suas fontes fundamentais de valor. Tal análise terá implicações para cada participante desta indústria embora não participem de todos os estágios.

Por exemplo, se o competidor A - uma firma totalmente integrada - calcular os retornos sobre os ativos em cada estágio da cadeia global, ajustando os preços de transferência a nível de mercado entre cada estágio, poderá detectar áreas onde talvez fosse mais vantajoso terceirizar do que executar internamente. Da mesma forma, os demais 
competidores conseguem identificar possibilidades de integração, para frente e para trás em áreas onde percebam poder obter um desempenho superior.

Por outro lado, cada atividade tem um conjunto de direcionadores de custos com fontes únicas de vantagens competitivas e as firmas enfrentam diversos tipos de competidores em cada estágio. Assim, por exemplo, a firma D enfrenta a competição das firmas A, C, e G na fabricação do papel e cada uma destas firmas competidoras possui uma vantagem competitiva diferente neste estágio frente a firma D. A firma D só poderá competir efetivamente com as demais, se compreender a cadeia total de valores e os condicionantes que regulam cada atividade. Por exemplo, se o condicionante competitivo fundamental é a integração vertical, a firma A tem uma vantagem competitiva e a firma D, uma desvantagem neste mercado.

Devido ao fato de que cada firma tanto é compradora como fornecedora, calcular o lucro ganho em cada estágio pode ajudar a entender a força relativa entre compradores e vendedores em cada estágio. Por exemplo, comparar o retorno da firma E versus o retorno da firma F, pode ajudar a identificar formas de explorar seus elos com fornecedores e clientes para reduzir custos e/ou diferenciar produtos.

Não basta mais para as empresas ter um lucro adequadamente medido pelos sistemas tradicionais, pois este lucro pode ser tragado pelo ambiente de mudanças rápidas existente na atualidade. Ao dividir a empresa em diversas atividades que geram valor e, levando em consideração as atividades de fornecedores e clientes (amplificação do conceito ), a cadeia destas atividades geradoras de valor propicia uma visão da situação e das vantagens competitivas de uma empresa para que ela possa medir e considerar os seus retornos estratégicos e traçar os caminhos mais adequados para o atendimento de uma rentabilidade sustentável e acima da média de seus concorrentes.

Já com relação à análise de custos tradicional, esta adota um enfoque por demais interno à firma - suas compras, suas funções, seus produtos e seus clientes. Outra maneira de se dizer isto é que a contabilidade gerêncial tradicional leva em conta a perspectiva de valor adicionado, começando com os pagamentos para fornecedores (compras) e terminando 
com o preço de venda para os clientes (vendas), sendo que o objetivo será maximizar a diferença - valor adicionado - acrescentado entre compras e vendas.

Mas o conceito de cadeia de valor é fundamentalmente diverso. Sob a perspectiva estratégica, o conceito de valor adicionado - preço de venda menos custo de matérias primas adquiridas - tem dois grandes problemas, segundo os autores "começa muito tarde e acaba muito cedo (SHANK \& GOVINDARAJAN, 1993, p. 14). Ao começar a análise de custos apenas a partir das compras da empresa, não são alcançadas todas as possibilidades de benefícios à serem extraídos das ligações com os fornecedores. O mesmo raciocínio é válido com relação aos distribuidores e compradores, pois as oportunidades para se explorar as relações com os clientes pode ser tão importante quanto a relação com os fornecedores. Outros aspectos não analisados pelo valor adicionado dizem respeito à interdependência entre as atividades de valor e seus respectivos elos e as conseqüências destes aspectos para o desempenho da empresas.

As abordagens convencionais tendem a enfatizar reduções de custos. Entretanto, reconhecendo as relações inter-elos, a análise da cadeia de valores admite a possibilidade de até se aumentar deliberadamente os custos em uma atividade de valor pois este aumento pode causar uma redução no custo total desta mesma cadeia.

O conceito de cadeia de valores além da sua inegável contribuição para o pensamento estratégico, oferece uma nova perspectiva com relação as análises empresariais que até então vinham se pautando pelo conceito de valor adicionado.

As seguintes observações podem ser colocadas:

- Devido ao fato de que virtualmente duas companhias não competem exatamente no mesmo conjunto de atividades de valor, a análise da cadeia de valores é uma primeira fase crítica para se entender como uma empresa está posicionada dentro de sua indústria. Construir uma vantagem competitiva sustentável requer um conhecimento de todo o conjunto de atividades de valor dos quais a empresa e seus concorrentes fazem parte.

- Uma vez que a cadeia de valores esteja completamente articulada, as decisões estratégicas críticas com relação a fazer ou comprar e para frente ou para trás, tornam-se 
mais claras. Decisões de investimento podem ser vistas sob a perspectiva de seu impacto sobre a cadeia global e a posição da empresa dentro desta cadeia.

- Sendo definida e explicada a cadeia de valores, as fases seguintes envolvem a compreensão dos fatores que influenciam o sucesso competitivo nos estágios chave da mesma.

- A análise da cadeia de valores ajuda a quantificar o poder de fornecedores e compradores, calculando a porcentagem do lucro total gerado ao longo da cadeia e que pode ser atribuída à eles. Este conhecimento ajuda a empresa a identificar formas de explorar elos com fornecedores e clientes.

\section{e) Metodologia de Construção e Uso}

De acordo com SHANK \& GOVINDARAJAN (1993), a metodologia para se construir a cadeia de valores de uma empresa, envolve as seguintes fases:

- Identificar a cadeia de valores e atribuir custos, rendimentos e ativos às atividades de valor que constituem esta cadeia. As atividades devem ser separadas se representarem uma porcentagem significativa dos custos operacionais, ou se o comportamento dos custos destas atividades (ou de seus direcionadores) for diferente, ou ainda se possuem um grande potencial para criar diferenciação. Para as atividades intermediárias que se encontram dentro da estrutura operacional da empresa, os rendimentos devem ser calculados ajustando-se os preços de transferência internos para preços de mercado competitivos.

- Identificar os direcionadores de custos: de acordo com a análise estratégica de custos, os direcionadores são parâmetros que influenciam o comportamento dos custos. Os custos, dentro de uma organização industrial, são causados ou dirigidos por diversos fatores interrelacionados entre si de uma forma complexa. É mais importante saber hoje como o comportamento dos custos é influenciado sob a ótica da competitividade do que saber qual o impacto no custo unitário de mudanças no volume de produção. Os fatores que direcionam e explicam o comportamento dos custos, definindo opções estratégicas, não mais se restringiriam a conceitos voltados para o volume de produção. Dentro de uma perspectiva mais ampla, tem-se outras formas estratégicas de dimensionamento de custos divididos em direcionadores estratégicos estruturais (escala, experiência, escopo, 
tecnologia , complexidade) e execucionais (comprometimento da força de trabalho, gestão pela qualidade total, etc.). Este conceito de direcionadores estratégicos de custos derivados dos direcionadores do custeio por atividades - ABC , já foram desenvolvidos em item anterior.

- Desenvolver a vantagem competitiva sustentável através do controle dos direcionadores de custos de um forma superior em relação aos concorrentes ou então redimencionando a sua própria cadeia de valores para se adaptar as novas exigências de mercado.

Com relação a este último item, os autores afirmam que no controle dos direcionadores, deve ser buscado uma situação na qual as atividades de valor sejam executadas com um custo minimizado ou produzindo um valor superior sempre em relação aos concorrentes. A vantagem competitiva é analisada sob o ponto de vista relativo, onde o importante não é a velocidade da empresa, mas se está indo mais depressa ou não que seus concorrentes.

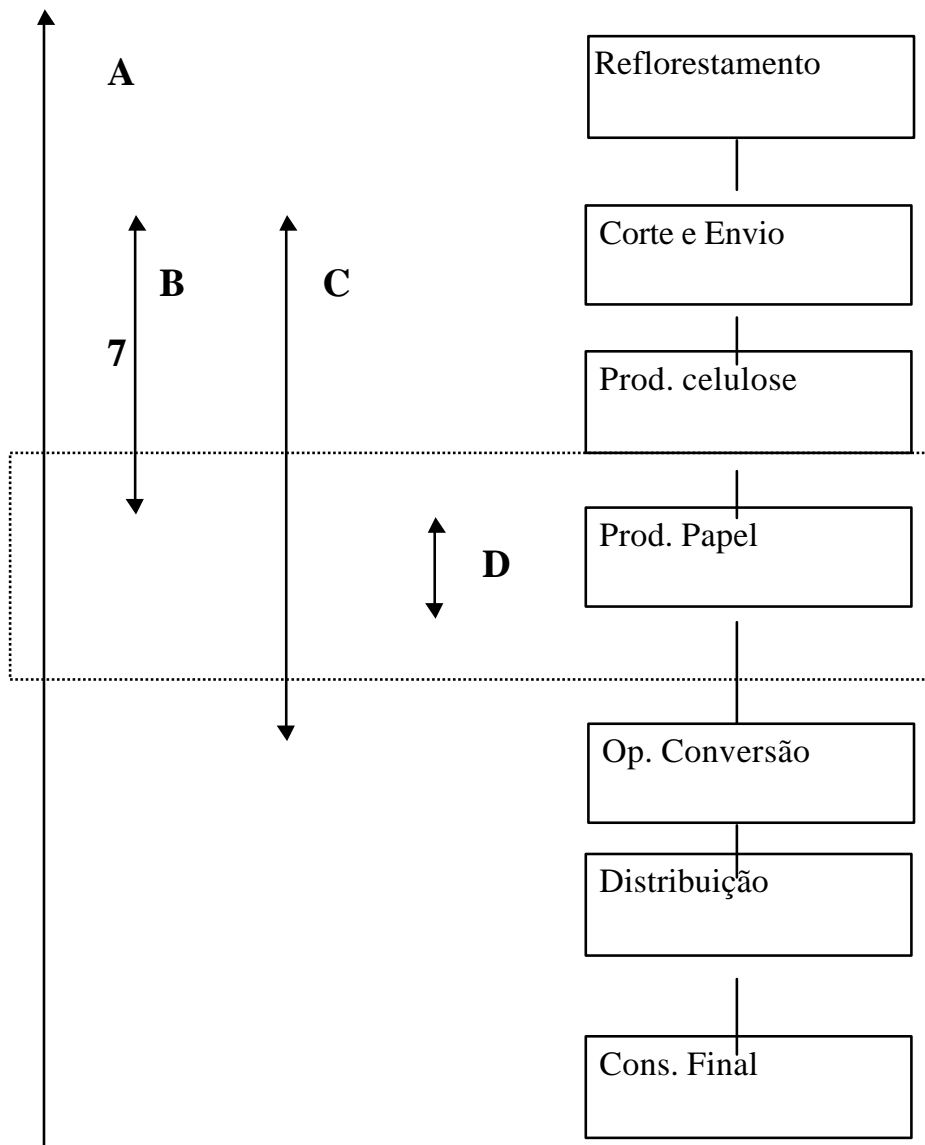


FIGURA 1- Cadeia de Valores da Indústria de Produtos de papel

\subsubsection{Análise do Posicionamento Estratégico}

De acordo com a concepção de vantagens competitivas preconizada por PORTER (1992), SHANK \& GOVINDARAJAN (1993) fazem uma combinação de tipos de metas, também chamadas missões, que as empresas costumam seguir e sua sintonia com as estratégias genéricas - liderança em custos e/ou diferenciação - seguidas por estas empresas. De um lado tem-se que enquanto missão (meta), a empresa pode seguir a missão denominada de construção, e que se constitui na busca de aumento da fatia de mercado sem uma preocupação muito atenta com as consequências disto para o fluxo de caixa no curto prazo. Esta modalidade de missão ou meta é típica de empresas com pequena participação de mercado em segmentos de grande crescimento. Ocorre geralmente em situações onde o ciclo de vida do produto está em fase de ascenção.

A missão colheita consiste na busca do máximo aproveitamento dos fluxos de caixa gerados pala exploração de determinado negócio no curto prazo, em detrimento dos possíveis efeitos que este enfoque possa ter na participação de mercado, geralmente a missão de colheita se verifica quando o ciclo de vida do produto se encontra em declínio; esta missão pode ser encontrada em empresas com grande participação de mercado em mercados declinantes.

A missão de manutenção significa a busca da proteção da participação de mercado, sendo característica de empresas com grande participação em mercados de rápido crescimento, esta missão é considerada uma modalidade intermediária entre as missões de construção e colheita.

Concluindo, o posicionamento estratégico se constitui em uma ferramenta decisiva para o SCM, pois o "processo de controle gerencial adequado é influenciado pelas estratégias que uma determinada empresa está seguindo", (SHANK \& GOVINDARAJAN, 1993, p. 136) e sendo assim "diferentes estratégias requerem diferentes perspectivas de controle" (SHANK \& GOVINDARAJAN, 1993, p. 137), e por fim “os sistemas de gestão de custos diferenciam-se de acordo com a estratégia" (Idem, 1996, p. 136). 
Por outro lado e de acordo com a visão associada aos conceitos de estratégia e vantagens competitivas, tem-se duas estratégias genéricas básicas e já mencionadas anteriormente: a busca da competição através de baixo custo e a competição baseada na diferenciação de produtos, cada uma com suas implicações específicas para o processo de negócio. Por exemplo, a busca da vantagem em diferenciação possui associadas a ela algumas características tais como maior incerteza, maior importância dada a inovação e maior diversidade de produtos, o oposto ocorrendo com a vantagem relacionada com o baixo custo. Também as formas de avaliação/desempenho dos negócios são diversas, dependendo da estratégia adotada. Enquanto que na estratégia de diferenciação as formas de avaliação são mais subjetivas, por exemplo o grau de interação com os clientes, nas empresas que seguem estratégias de baixo custo os resultados são avaliados com base nos lucros gerados com as operações. Então na primeiro caso - diferenciação - se observa uma empresa voltada para questões de inovação que lhe propiciem posições de mercado vantajosas, enquanto que no segundo caso a empresa estará mais voltada para melhorias e modificações relacionadas com reduções contínuas de custos.

Dependendo do tipo de missão e da estratégia genérica, tem-se uma forma de se tratar a gestão e os controles gerenciais de uma empresa. Percebe-se também que existe uma paralelo entre missão e vantagem competitiva, pois as empresas costumam trabalhar com as duas perspectivas ao mesmo tempo. As combinações entre estratégia e missão mais recomendáveis propostas em SHANK \& GOVINDARAJAN (1993) são as que não implicam em situações geradoras de desequilíbrios, por exemplo um binômio incompatível seria o que soma a missão de construir com a estratégia de baixo custo pois a missão de construção implica em investimentos em tecnologia, riscos, incertezas e sacrifícios de curto prazo que, em termos de fluxo de caixa, são incompatíveis com controle de custos. Outro binômio potencialmente desestabilizante é o binômio colher-diferenciação, pois se encontra em mercados maduros incompatíveis com os investimentos necessários para se colocar um produto diferenciado no mercado.

Assim, as combinações mais adequadas, segundo aos autores, seriam as que trazem compatibilidade na sua associação, vale dizer, os binômios baixo custo-colheita ou diferenciação - construção. 


\section{3 Matrizes de Compatibilidade e Adequação}

Até este estágio do trabalho, foram detalhadas a emergência das Empresas Virtuais como um novo modelo organizacional em resposta aos novos rumos e exigências competitivas e tecnológicas do mercado globalizado, e a proposta da Gestão Estratégica de Custos - SCM - enquanto ferramenta administrativa e alternativa a ser utilizada pelas Empresas Virtuais como geradora de informações econômico-financeiras para a análise de lucratividade e tomada de decisões. Cumpre agora aprofundar e finalizar a análise no sentido de se detalhar e aferir as possibilidades de adequação do SCM e seus instrumentos (cadeia de valores, direcionadores estratégicos e posicionamento estratégicos) aos diversos processos que formam o desenho operacional das Empresas Virtuais. Assume-se que existe a necessidade de se aplicar alguma forma de gestão de custos às Empresas Virtuais e seus processos pois estas, tanto quanto as empresas organizadas de forma mais tradicional, precisam de instrumentos que lhes possibilitem condições e informações para a divisão de ganhos, cálculo de desempenho e principalmente tomada de decisões.

O objetivo é explorar as possibilidades de efetiva utilização das ferramentas de SCM e sua correspondência com os processos de Empresas Virtuais inicialmente no que tange a sua compatibilidade (correspondência efetiva). Posteriormente, num refinamento da compatibilidade, dentre as associações compatíveis serão selecionadas aquelas com maiores possibilidades de adequação, ou seja, de real implementação. Para a melhor visualização deste exercício, o recurso proposto e utilizado aqui será o de matrizes - uma para a compatibilidade e outra para a adequação - que irão demonstrar a relação entre as ferramentas de SCM e os processos constitutivos de Empresas Virtuais. Cada ponto de encontro entre estes dois fatores receberá a denominação de associação e será constituída de dois números: o primeiro representando as ferramentas SCM e o segundo os processos de Empresas Virtuais.

É importante salientar que o objetivo destas matrizes é uma proposta teórica de referência para futuros trabalhos e projetos de caracterização e implementação de sistemas de Gestão Estratégica de Custos, sendo que a base indicativa para estes trabalhos seriam as associações resultantes das análises de compatibilidade e adequação. Estas associações 
futuramente poderão ser utilizadas como um ponto de partida por Empresas Virtuais que pretendam realizar a configuração de um sistema de Gestão Estratégica de Custos para suporte de tomada de decisões.

\subsubsection{Matriz de compatibilidade}

Como já foi mencionado, a primeira matriz irá tratar da compatibilidade entre ferramentas SCM e processos de Empresas Virtuais assinalando se determinada ferramenta SCM, atende às exigências e necessidades de um certo processo de Empresa Virtual. Esta matriz está representada a seguir (FIGURA 2) e demonstra as alternativas de aplicação compatíveis das ferramentas de SCM em associação com os processos de Empresas Virtuais.

O objetivo neste momento é inferir em que medida o SCM através de suas ferramentas e segundo a proposta desenvolvida em SHANK E GOVINDARAJAN (1993) exposta no item 3.2, se adapta de forma compatível às características e necessidades específicas de cada processo de Empresa Virtual de acordo com a estrutura do modelo de GORANSON (1995) detalhada no item 3.1, em uma aplicação conjunta das ferramentas SCM em processos de Empresas Virtuais.

Assim, por exemplo, tem-se uma associação 1-3, entre a ferramenta Cadeia de Valores e o processo Formação considerada incompatível pelo fato de que neste processo a ênfase é na construção efetiva do negócio, no detalhamento da missão estratégica, dos critérios que nortearão as parcerias e demais parâmetros do empreendimento tais como especificação do produto e fontes de recursos. Neste estágio, a análise de Cadeia de Valores (no conceito ampliado) não faz muito sentido pois o empreendimento está voltado para os seus fatores mais internos e rotineiros e não as implicações externas de relações com clientes e fornecedores ao longo da cadeia em questão. As mesmas razões são válidas para explicar a incompatibilidade da associação 1-4 (análise da Cadeia de Valores - Operação da Empresa Virtual), pois o processo Operação da Empresa Virtual também traz em si um enfoque interno. 
Por outro lado existe uma compatibilidade mais evidente destes processos com a ferramenta Direcionadores de Custos (associações 2-3 e 2-4), pois a definição dos direcionadores nos estágios de Formação e Operação são importantes para os detalhes e fatores relevantes de custeio das operações do negócio. No mesmo raciocínio, os processos Identificação de Oportunidades e Escolha de Parceiros, que já se realizaram antes da Formação e Operação, possuem uma compatibilidade mais evidente com a ferramenta Cadeia de Valores (associações 1-1 e 1-2) devido a natureza mais externa de seu enfoque, nestes dois processos é muito importante se ter uma exata dimensão das implicações mais gerais de se explorar uma oportunidade e com quais parceiros e aqui a análise da Cadeia de Valores com sua visualização amplificada e aberta da situação estratégica e econômica da Empresa Virtual, poderá em princípio fornecer os subsídios necessários.

\section{PROCESSOS DE EMPRESAS VIRTUAIS}

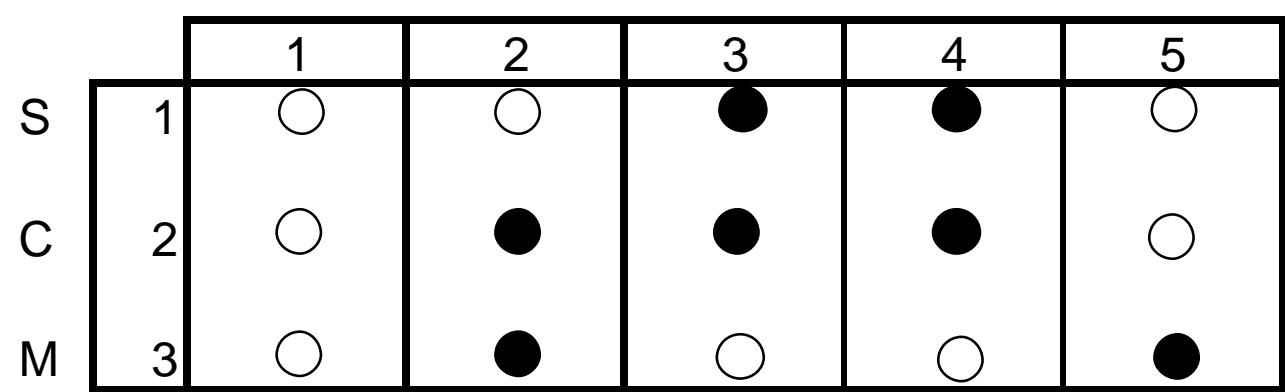

Ferramentas de SCM

Compatível

1. Cadeia de Valores

2. Posicionamento Estratégico

3. Direcionadores de Custos
Processos de Empresas Virtuais

1. Identificação de Oportunidades

2. Seleção de Parceiros

3. Formação

4. Operação

5. Reconfiguração e Dissolução 
FIGURA 2 - Matriz de Compatibilidade ferramentas de SCM x processos de EV

Se constata uma compatibilidade entre a ferramenta Cadeia de Valores e o processo Reconfiguração e Dissolução (associação 1-5). Neste processo, tal qual os processos Identificação de Oportunidades e Seleção de Parceiros, o enfoque externo e amplificado dado pela análise da Cadeia de Valores se mostra oportuno para a tomada de decisões.

No que concerne à ferramenta Posicionamento Estratégico, são encontradas incompatibilidades nos processos de Seleção de Parceiros, Formação, Operacionalização (associações 2-2, 2-3, 2-4). Tendo em vista esta ferramenta estar mais voltada para o setor externo da empresa (até mais que a ferramenta Cadeia de Valores), um enfoque que não se revela tão prioritário nestes processos. Nos processos de Identificação de Oportunidades e Reconfiguração e Dissolução, o Posicionamento Estratégico é importante na tomada de decisões, razão pela qual estes processos (associações 2-1 e 2-5) serão considerados compatíveis com a ferramenta Posicionamento Estratégico.

No que tange à ferramenta Direcionadores de Custos, além da compatibilidade encontrada nas associações 3-3 e 3-4 já mencionadas, tem-se a compatibilidade na associação 3-1. No processo de Indentificação de Oportunidades, algumas oportunidades poderão ser descartadas ou não, tendo em vista a definição dos Direcionadores destas oportunidades e se estes mesmos Direcionadores estão presentes ou poderão ser implementados na Empresa Virtual. Por fim, verifica-se uma incompatibilidade nas associações 3-2 e 3-5, onde análsie de Direcionadores de Custos não se constitui em fator fundamentais para a tomada de decisões em termos de Seleção de Parceiros e de Reconfiguração e Dissolução.

\subsubsection{Matriz de Adequação}

Na matriz de Adequação, cuja representação se encontra a seguir, (FIGURA 3), o objetivo é inferir se a situação gerada por cada associação é adequada para a implantação de ferramentas de Gestão Estratégica de Custos em determinados processos de Empresas 
Virtuais. Em outras palavras, o que se deseja saber é se uma determinada associação entre uma ferramenta de Gestão Estratégica de Custos e um processo de Empresa Virtual, possui chances razoáveis de implementação prática. Trata-se também de um refinamento da matriz de compatibilidade tendo em vista que apenas são destacadas nesta matriz de adequação as associações anteriormente consideradas compatíveis.

Exemplificando, apesar da compatibilidade anterior registrada na associação 3-3 (Posicionamento Estratégico/Formação) e devido principalmente à definição da missão a ser seguida existente neste processo, as possibilidades reais de implantação não são tão nítidas quanto por exemplo as da associação 1-1 (Cadeia de Valores/Identificação de Oportunidades). No que tange ao processo Identificação de Oportunidades, uma maior sintonia também é constatada pelo conhecimento e prática do Posicionamento Estratégico e aí se obtém uma outra associação, 2-1 adequada e passível de implementação por razões semelhantes as da associação 1-1.

Na associação 1-5 (Cadeia de Valores/Reconfiguração) surge uma outra adequação. Uma análise de Cadeia de Valores neste processo se revela tão importante e possível quanto no processo Identificação de Oportunidades. Neste momento a Empresa Virtual deverá ter uma visão o mais ampla e estratégica possível das suas possibilidades e implicações de se dissolver ou reconfigurar e as repostas podem ser encontradas mediante uma análise correta da Cadeia de Valores na qual está inserida. Outra associação considerada adequada se encontra na conjunção da ferramenta Posicionamento Estratégico com o processo Operação. Uma vez que este processo se constitui na Empresa Virtual propriamente e dita, ou no seu dia a dia, faz-se necessário que a perspectiva estratégica esteja presente para nortear a tomada de decisões.

Quanto às demais associações consideradas inadequadas neste estágio, tem-se que, no caso da associação 3-1 (Direcionadores de Custos/Identificação de Oportunidades) o processo Identificação de Oportunidades as possibilidades de implantação são reduzidas e além do mais a análise de Cadeia de Valores e de Posicionamento Estratégico já estando presentes neste processo (associações 1-1 e 2-1) deixa o mesmo suficientemente coberto em termos de instrumentos de Gestão Estratégica de Custos. Já no processo Seleção de Parceiros, a análise de Cadeia de Valores também possui suas limitações em termos das 
possibilidades concretas de sua implantação, outras variáveis tais como bancos de dados sobre os parceiros e definições de competências essenciais de futuros parceiros e portanto a associação 1-2 não será considerada adequada. Por fim, no que tange ao processo de Reconfiguração e Dissolução, reconhece-se a importância da análise de Posicionamento Estratégico, mas a tomada de decisões estará muito mais amparada na correta análise de Cadeia de Valores (associação1-5) tal como na associação 1-1 (análise de Cadeia de Valores/Identificação de Oportunidades) assim a adequação da associação 2-5, para este processo se torna menos evidente que em outras associações.

\section{PROCESSOS DE EMPRESAS VIRTUAIS}

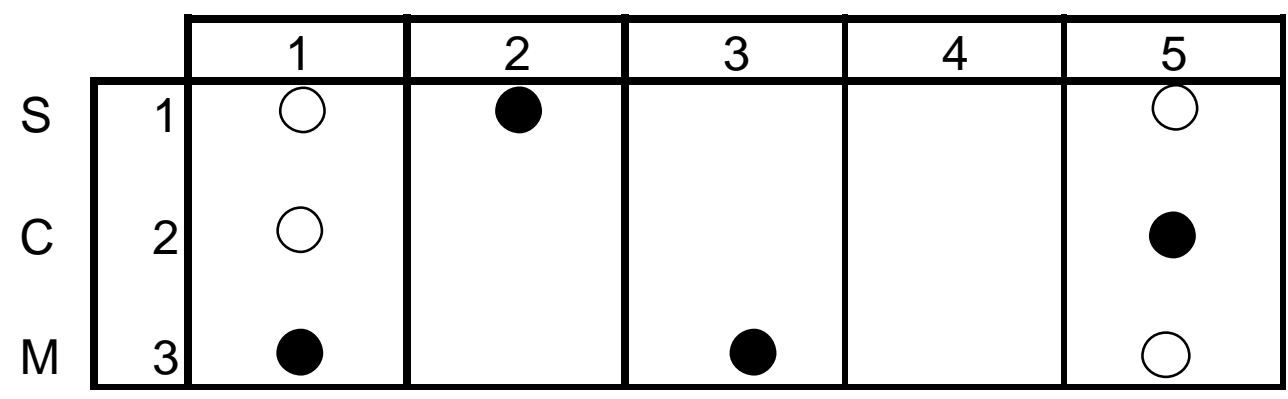

Adequado

Inadequado

Ferramentas de SCM

Processos de Empresas Virtuais

1. Cadeia de Valores

2. Posicionamento Estratégico

3. Direcionadores de Custos
1. Identificação de Oportunidades

2. Seleção de Parceiros

3. Formação

4. Operação

5. Reconfiguração e Dissolução 


\subsubsection{Resultados}

Após a representação das matrizes de compatibilidade e adequação, se constata que dentre as inúmeras possibilidades de combinações entre ferramentas SCM e processos de Empresas Virtuais, apenas as associações destacadas após a análise de adequação se sobressaem como opções concretas de uma análise mais profunda e uma maior sintonia com os objetivos deste trabalho. Portanto, quatro associações emergem como as que apresentam uma correspondência com as possibilidades de estudo e detalhamento aprofundado, são as associações 1-1, 2-1, 1-5 e 3-4, sendo que as descrições e considerações sobre cada uma são colocadas a seguir.

Serão feitas considerações sobre cada associação em termos das implicações da ferramenta SCM em questão para cada subdivisão de seu processo correspondente de acordo com a estrutura proposta por GORANSOM (1995) e descrita no item 3.1.2. Na associação 1-1, por exemplo a ferramenta Cadeia de Valores será analisada em termos de sua correspondência com os processos secundários que constituem o processo principal Identificação de Oportunidades, e assim por diante.

\section{a) Associação 1.1 - Cadeia de valores/ Identificação de oportunidades}

No subprocesso Estratégia de Oportunidades, uma visão estratégica que leve em conta, por exemplo, a configuração da Cadeia de Valores ampliada do setor no qual a empresa está inserida bem como a Cadeia de Valores interna à empresa (segundo conceituação de PORTER, 1992) será importante na tomada de decisões de uma Empresa Virtual. Vale dizer que a prática de análise de Cadeia de Valores por uma empresa, no que tange ao subprocesso de Estratégia de Oportunidades, favorece este mesmo subprocesso para a empresa que a adota na medida em que fornece uma visão mais clara e abrangente das possibilidades, identificando oportunidades que talvez não fossem percebidas por uma empresa que segue a gestão tradicional ou, por outro lado, rejeitando outras oportunidades que normalmente a empresa se sentiria atraída com a visão distorcida das possibilidades que as informações de custos produzidas pelos modelos tradicionais, acabam por fornecer. 
Uma Empresa Virtual que trabalha com a perspectiva de Cadeia de Valores no pode enxergar com mais propriedade do que uma empresa sem esta perspectiva se uma determinada oportunidade vale a pena ser empreendida ou não. Também a correta análise da Cadeia de Valores deve estar presente (tanto no conceito estrito como no ampliado) pois ela vai informar quais as possibilidades de alianças mais compatíveis e quais as vantagens competitivas existentes vis a vis as oportunidades que se apresentam e a viabilidade de se explorar ou não estas oportunidades.

No subprocesso Exposição, a questão da implementação de uma análise de Cadeia de Valores se torna relevante no que tange à integração com os potenciais parceiros, fornecedores e clientes. A análise ampliada da Cadeia de Valores propicia uma visão de custo/benefício mais adequada e ajuda a Empresa Virtual a decidir sobre os critérios da exposição a ser efetuada para se sinalizar e atrair parceiros na exploração conjunta das oportunidades.

Com relação à Definição de Mercado a análise de Cadeia de Valores irá ajudar na medida em que o mercado e as suas necessidades, bem como as competências para atendêlos serão melhor compreendidos sob a luz ampliada da Cadeia de Valores na qual a Empresa Virtual pretende se situar. Conhecendo a sua Cadeia de Valores na sua totalidade a Empresa Virtual poderá se situar em termos de mercado de uma forma mais precisa.

A Cadeia de Valores, no que tange a Procura de oportunidades em si, propiciará a visão mais precisa sobre as oportunidades que estejam mais sintonizadas com a Cadeia de Valores relativa à uma Empresa Virtual e que propiciem melhores chances de sucesso para toda a Cadeia e não apenas para uma empresa isolada. 


\section{b) Associação 2.1 - Posicionamento Estratégico/Identificação de}

\section{oportunidades}

O simples fato de se mencionar que existe a necessidade de uma Estratégia de Oportunidades explícita dentro do processo de Identificação de Oportunidades (porém não excessivamente exposta aos concorrentes) sugere a existência de algum tipo de gestão ou Posicionamento Estratégico, talvez não necessariamente de natureza voltada para custeio, mas certamente o Posicionameno Estratégico estará presente como ponto de partida para se traçar um estratégia consistente que neste caso se constitui de uma missão clara que oriente a busca de oportunidades.

No subprocesso Definição de Mercado, a ferramenta Posicionamento Estratégico guarda uma correspondência estreita pois a sintonia das competências essenciais com as necessidades e oportunidades de mercado se fará tendo como pano de fundo a posição estratégica, ou seja, forma de competição adotada pela Empresa Virtual.

Especificamente com relação à Procura de Oportunidades, a necessidade da existência de processos e procedimentos para a prospeção de oportunidades se dará com melhor efeito através da prática da ferramenta em destaque pois o Posicionamento Estratégico dará os limites que a nortearão as opções e escolhas disponíveis no mercado

\section{Associação 1.5 - Cadeia de valores/Reconfiguração e Dissolução}

Um dos principais atributos da prática do SCM é a geração de informações de custos menos distorcidas e que otimizam a tomada de decisões. As decisões dentro de um contexto que requer Reconfiguração e Dissolução, geram a necessidade de decisões bem embasadas neste sentido pois muitas vezes podem se constituir caminhos sem volta. Consequentemente, é relevante a prática do SCM e mais específicamente da Cadeia de Valores no que tange a este processo de Empresa Virtual.

Com relação ao subprocesso de Identificação de Novas Necessidades, tem-se que através da Cadeia de Valores, esta identificação torna-se apropriada e sintonizada com as 
possibilidades de negócio pois a Empresa Virtual estará antevendo possibilidades de novas atuações em mercados que talvez seriam descartáveis quando analisados sob a ótica da gestão tradicional de custos, mais voltada para os fatores operacionais internos.

Em termos de outro subprocesso, o de Dispersão de Ativos e Patrimônio, a própria necessidade de se mensurar os ativos e direitos irá produzir diferenças consideráveis se o SCM e mais especificamente a análise de Cadeia de Valores for adotada, pois determinado ativo que possuiria um valor considerável segundo a gestão tradicional, poderá não ser valorado da mesma forma quando o componente estratégico inserido na ferramenta Cadeia de Valores for incluído na análise.

\section{Associação 3.4 - Direcionadores de Custos/Operação}

Dentro do espírito de funcionamento de uma grande empresa no processo Operação de uma Empresa Virtual, o dia a dia inclui decisões relacionadas com custeio, avaliações períodicas sobre desempenho das operações baseadas em fatores críticos sobre os custos. Portanto a presença dos Direcionadores de Custos se faz necessária no sentido de fornecer maiores subsídios para a tomada de decisões operacionais

Com relação às Medidas de Desempenho, estas estão relacionadas com a estrutura de recompensa e risco existente no arranjo organizacional das Empresas Virtuais. Tem a finalidade de oferecer aos gestores uma visão da situação coletiva e individual que possibilite aos mesmos um entendimento correto das condições dinâmicas de suas operações. Contudo, para se chegar a uma conclusão mais sintonizada com o ambiente globalizado e de concorrência acirrada no qual estão inseridas as Empresas Virtuais, e tendo em vista as mesmas medidas de desempenho, é preciso que se tenha claro quais os fatores que direcionam os custos. Em outras palavras, uma Empresa Virtual que por exemplo tenha como Direcionador de Custos a escala de produção terá medidas de desempenho estruturadas sob bases diversas daquelas onde o Direcionador seja a Qualidade. Sem estes parâmetros a análise e a tomada de decisão será restrita a fatores relacionados com volume de produção ou outro fator interno que não irão propiciar a informação de conteúdo estratégico e consequentemente a decisão mais apropriada requerida. 
Em termos do subprocesso de Relações Com os Clientes, o componente estratégico ligado este relacionamento é evidente e a análise de Direcionadores de Custos irá proporcionar uma visão mais acurada das possibilidades de relacionamento com os mesmos, uma vez que a Empresa Virtual estará em condições de interagir com seus clientes amparada no conhecimento e na operação dos Direcionadores de Custos referentes ao seu negócio e ao de seus clientes e parceiros.

\section{CONCLUSÕES}

Através da revisão de literatura, se verificou que a questão dos custos e de sua contabilidade passa a ser crítica para o sucesso das organizações e das pessoas que trabalham nelas, uma vez que as informações relativas aos custos são base importante para a tomada de decisões. Com as transformações dos últimos anos, as organizações tem cada vez mais enfrentado a necessidade de um maior entendimento e controle de seus custos, de maiores informações relativas a estes custos e ao efeito das decisões empresariais sobre os mesmos. Devido ao incremento da concorrência e a diminuição das margens de lucro decorrente deste aumento, a simples transferência dos custos para o preço final se torna cada vez mais delicada. Mais do que nunca, a correta administração de custos passa a ser fundamental para a sobrevivência das empresas dentro de um ambiente de concorrência acirrada seja ela globalizada ou localizada. De todo modo, com a expansão da capacidade de processamento de informações e as mudanças tecnológicas, o enfoque da gestão de custos deve necessariamente ser modificado para se adequar às novas exigências.

Também após a já referida revisão, fica claro que os adventos da globalização e da revolução tecnológica pressupõem a abertura para novas concepções de atuação empresarial, dentre as quais, surge uma nova concepção que privilegia a operação em redes de cooperação, sejam elas ligadas entre si ou subordinadas à uma empresa central de maior porte e visando sempre a exploração de uma oportunidade de mercado. No caso das empresas interligadas sem a existência de uma empresa central, se observa que as mesmas 
seguem atuando de forma independente e coordenada (e quase sempre temporária), explorando complementaridades mútuas, em um modelo denominado de Empresa Virtual.

Diante deste quadro, se constata que os sistemas de custos que vem sendo utilizados estão ficando obsoletos e inadequados e esta inadequação se verifica especialmente para o setor que pretendemos aqui estudar, as Empresas Virtuais. Apenas determinar e calcular custos da forma mais tradicional não atende mais à exigências de um ambiente de concorrência acirrada onde além de ser melhor, também se deve ser mais rápido. Esta realidade se mostra ainda mais evidente no contexto de mercado concorrencial das Empresas Virtuais onde o valor das informações para tomada de decisões assume importância não só em termos de operação interna, mas na prospecção de novas oportunidades e sua exploração.

Para uma Empresa Virtual, o correto equacionamento dos custos terá seus efeitos sobre a efetivação da cooperação da mesma e, consequentemente, sobre seu sucesso na medida que as informações de custos se tornaram cada vez mais importantes para a tomada de decisões. No ambiente globalizado a gestão tradicional de custos não mais atende às necessidades de informações para tomada de decisões com flexibilidade e rapidez. Concluese que esta necessidade se torna mais premente nas Empresas Virtuais, pois as mesmas pretendem atuar em segmentos com forte conteúdo tecnológico e concorrência acirrada e cujo caráter de trabalho coordenado faz com que as decisões relativas a custos devam estar ainda mais amparadas em informações sintonizadas com as exigências dos novos padrões de concorrência global.

Assim sendo, parece factível assumir a possibilidade de se aplicar a Gestão Estratégica de Custos e suas ferramentas analíticas ao modelo de Empresa Virtual, pelo menos no que tange a alguns de seus processos constitutivos de forma mais explícita e sistemática. Neste sentido, o SCM, através de suas ferramentas analíticas deve então, não só proporcionar as condições de geração destas informações como também avaliar se a empresa deve atuar em rede ou não.

Dentro deste contexto, as matrizes de compatibilidade e adequação tiveram por objetivo auxiliar na indicação de quais destes processos seriam mais propícios à aplicação de 
ferramentas de SCM e os resultados iniciais deste exercício teórico se fizeram representar no item 3.3.3.

O sistema de Gestão Estratégica de Custos/SCM tal como foi sistematizado neste trabalho, em uma combinação das contribuições de PORTER e SHANK \& GOVINDARAJAN, revela reais possibilidades de implantação não só em Empresas Virtuais mas também em outras formas de empresa sendo que uma futura implantação integrada de um sistema SCM para um determinado tipo de Empresa Virtual deverá seguir as características próprias da mesma não só em termos operacionais como também em termos de suas expectativas e necessidades.

Através das matrizes de compatibilidade e adequação se obteve também um caminho e um padrão possível de implantação de um sistema de SCM para o caso de Empresas Virtuais, pois são definidas de forma mais clara as combinações de processos de Empresas Virtuais/ferramentas SCM mais propícios à estruturação de uma real implantação.

Tendo em vista a existência das Empresas Virtuais como uma possibilidade real de atuação empresarial dentro do novo ambiente organizacional e sendo o SCM uma alternativa interessante de mensuração e análise de custos mais sintonizada com este novo ambiente e após ter chegado em vista disto à uma série de combinações possíveis de aplicação de determinadas ferramentas de Gestão Estratrégica de Custos à análise de custos de determinados processos relacionados com as Empresas Virtuais, cumpre então algumas sugestões de futuros trabalhos de cunho mais empírico relacionado com a real aplicabilidade destas combinações em situações reais de Empresas Virtuais.

Um trabalho que seria em certa medida uma extensão e ao mesmo tempo comprovação da análise teórica realizada aqui seria aquele que, a partir de uma Empresa Virtual já existente, realizasse a aplicação e o teste das combinações acima destacadas entre processos e ferramentas, documentando os resultados obtidos e atingindo assim uma conclusão mais embasada na prática a cerca das reais possibilidades de implantação do SCM e de suas ferramentas em Empresas Virtuais. 
Uma sequência deste trabalho seria uma implantação de fato de um sistema SCM em Empresas Virtuais, de acordo com as associações aqui obtidas, buscando-se uma validação das propostas deste trabalho e constituindo-se o mesmo, desde de que devidamente validado e aperfeiçoado, em um material de orientação para as Empresas Virtuais que pretendam efetuar a implantação de um sistema de Gestão Estratégica de Custos.

Assim, questões práticas tais como, qual a forma de se usar o SCM na gerência de Empresas Virtuais ou como mesurar, analisar e controlar os custos das Empresas Virtuais e por fim, qual a contribuição que pode ser dada por um sistema SCM na gestão de uma Empresa Virtual, poderão ser melhor respondidas.

Por fim, poderíamos destacar dois outros trabalhos que poderão ser realizados:

- Criação de um modelo de Gestão Estratégica de Custos adequado à uma Empresa Virtual.

- Base teórica para a criação de sistemas de gestão de custos que visem a transformação de uma empresa brasileira que opera de forma tradicional para uma empresa passível de integração a uma Empresa Virtual 


\section{REFERÊNCIAS BIBLIOGRÁFICAS}

BACIC, MIGUEL J. (1994). Escopo da Gestão Estratégica de Custos em face das noções de competitividade e de estratégia empresarial. In: CONGRESSO BRASILEIRO DE GESTÃO ESTRATÉGICA DE CUSTOS, 1., São Leopoldo, 1995. Anais. Rio Grande do Sul, UNISINOS. v1, p. 295-04.

BACIC, MIGUEL J., SOUZA, CAROLINA M. F. (1994). Desenvolvimento da cooperação entre empresas como instrumento para enfrentar os custos de complexidade. In: CONGRESSO BRASILEIRO DE GESTÃO ESTRATÉGICA DE CUSTOS, 1., São Leopoldo, 1995. Anais. Rio Grande do Sul, UNISINOS, v1, p. 305-17

BACIC, MIGUEL JUAN, SOUZA, CAROLINA M. F. (1996). Identificação e exploração de oportunidades de inter-relações e consolidação de redes de empresas: espaço para expansão do escopo analítico da Gestão Estratégica de Custos. In: CONGRESSO BRASILEIRO DE GESTÃO ESTRATÉGICA DE CUSTOS, 3., Curitiba, 1996. Anais. Paraná, p. 01-12 
BAUMANN, R. (1996). Globalização: a adesão compulsória Jornal do Economista CORECON/SP, n 95, p 8-10, dez/96. [Entrevista]

CASTRO, A B. (1995). Jornal do Economista - CORECON/SP, n. 76, p. 6-7, maio/95. [Entrevista].

CERTO, S. C., PETER, J. P. (1993). Administração estratégica. São Paulo, Makron Books.

CHESBROUGH, HENRY W., TEECE, DAVIS J. (1996). When is virtual virtous? Harvard Business Review. p 65-73, jan.-fev.

COUTINHO, L. (1992). A terceira revolução industrial e tecnológica: as grandes tendências de mudança Economia e Sociedade - UNICAMP, n. 1, p. 69-87, ago.

COUTINHO, L. (1995). Nota sobre a natureza da globalização Economia e Sociedade UNICAMP, n. 4, p. 21-26, jun.

COUTINHO, L., Ferraz, J. C., coord. (1994). Estudo da competitividade da indústria brasileira. Campinas, Papirus.

DRUCKER , P. F. (1994). Sociedade Pós-Capitalista. São Paulo, Pioneira.

GOLDMAN, S. L.; NAGEL, R N.; PREISS, K. (1995). Agile competitors - concorrências e Empresas Virtuais, estratégias para valorizar o cliente. São Paulo, Érica.

GORANSON, T. (1995). Agile virtual enterprise - best agile practice reference base

HAMEL, G.; PRAHALAD, C. K. (1994). Competindo pelo futuro - estratégias inovadoras para obter o controle do seu setor e criar mercados de amanhã. Rio de janeiro, Harvard Business Press/ Campus. 
HANDY, C. (1995) Trust and the virtual organization. Harvard Business Review. p 40-49, mai.- jun.

KUMAR, K. (1997). Da sociedade pós-industrial à pós-moderna - novas teorias sobre o mundo contemporâneo. Rio de Janeiro, Zahar.

MAHER, M. W., DEAKIN, E. B. (1994). Cost Accounting. Boston/E.U.A , IRWIN.

MAZZALI, L.; COSTA, Vera M. H. M. (1997). As formas de organização "em rede": configuração e instrumento de análise da dinâmica industrial recente . Revista de Economia Política, v. 17, n. 4, p. 121-137, out.-dez

NAKAGAWA, M. (1991). Gestão Estratégica de Custos. São Paulo, Atlas.

NAKAGAWA, M. (1994). ABC - custeio baseado em atividades. São Paulo, Atlas.

NAKANO, Y. (1994). Globalização, competitividade e novas regras de comércio mundial. Revista de Economia Política, v. 14, n. 4, p. 7-30, out.-dez.

PORTER, M. E. (1992). Vantagem competitiva - criando e sustentando um desempenho superior. Rio de Janeiro, Editora Campus.

PORTER, M. E. (1986). Estratégia competitiva - técnicas para análise de industrias e da concorrência. Rio de Janeiro, Campus.

PORTER, M. E. (1996). What is strategy ? Harvard Business Review. p 61-78, nov-dez

RONDINO, R., (1996). Globalização: O Que É e Suas Implicações - 23 e 24 de maio de 1996, FEA-USP Jornal do Economista - CORECON/SP, n. 89, p. 6-7, junho/1996. [Relato da Agencia Estado]

SIEBER, P., (1997). Virtual organizations: static and dinamic viewpoints. Htpp//WWW.Virtual Organizations.Net. Newsletter vol. 1 No 2. Abr./97 
SHANK, J. K; GOVINDARAJAN, V. (1993). Gestão Estratégica de Custos - a nova ferramenta para a vantagem competitiva. Rio de Janeiro, Campus.

STALK, G.; EVANS, P.; SHULMAM, L. (1992). Competing on capabilities: the new rules of corporate strategy. Harvard Business Review. p 57-69, mar-abr.

TAUILE, J. R. (1994). Flexibilidade dinâmica, cooperação e eficiência econômica: anotações. Revista de Economia Política, v. 14, n.1, p. 85-99, jan. - mar.

VELOSO, L. A . (1995). Administração estratégica de custos - buscando o reposicionamento através da competitividade. In: CONGRESSO BRASILEIRO DE GESTÃO ESTRATÉGICA DE CUSTOS, Campinas, 1995. Anais. Editora UNICAMP. V. 1, p. 393-05.

ZINI, A J. (1996). Conferência globalização, Jornal do Economista - CORECON/SP, n. 88, p. 10-12, maio/96. [Entrevista]. 